\title{
False Imprisonment \& Refusing to Assist a Police Officer - The Need for Statutory Offences
}

\author{
Graham McBain ${ }^{1,2}$ \\ ${ }^{1}$ Peterhouse, Cambridge, UK \\ ${ }^{2}$ Harvard Law School, USA \\ Correspondence: Graham McBain, 21 Millmead Terrace, Guildford, Surrey GU2 4AT, UK. E-mail: \\ gsmcbain@aol.com
}

Received: June 11, 2015 Accepted: June 27, 2015 Online Published: July 24, 2015

doi:10.5539/jpl.v8n3p51 URL: http://dx.doi.org/10.5539/jpl.v8n3p51

\section{Introduction}

There are a number of areas of English criminal law which require modernisation. A previous article has reviewed the law in relation to escape, prison breach and rescue ${ }^{1}$ which, it argues, should now be made statutory offences. This article considers the law in relation to false imprisonment. The two are connected. The former involves a person escaping from lawful custody. The latter involves a person being detained other than in lawful custody.

- Both these criminal offences have had a long history and both, originally, were especially connected with 'imprisonment'. 2 That is, detention in a jail or being detained by a police constable, headborough (borsholder) or other police official; ${ }^{3}$

- As with the common law offence of escape etc. false imprisonment is a common law offence. It is punishable with imprisonment or a fine (or both). ${ }^{4}$ Kidnapping is a sub-category of false imprisonment.

It may be noted, from the outset, that the words 'false imprisonment' can be confusing in a modern context. 'False' being derived from the Anglo-Norman (Law French) is, perhaps, better translated as 'unlawful.' And 'imprisonment' summons up the image of a prison, whereas the offence covers any form of detention - whether in a building or not. Further, it can be committed by any person. Thus, as will be seen, it would seem better if a modern statutory offence were to be termed 'Unlawful Detention'. 6

The purpose of this article is to review the common law on false imprisonment and to propose that it become a statutory offence. It is useful to consider the history of false imprisonment in some detail since it was especially connected, in early times, with unlawful custody in prisons and by police constables. In this article, reference is made to my previous article on escape, by way of background. ${ }^{7}$ This article also considers the common law offence of refusing to assist a police officer. Like false imprisonment it derives from early English law. This article argues that it also should become a statutory offence. As to legal texts dealing with these offences, those of importance include the following:

- H Bracton, On the Law and Customs of England (c. 1240); 8

- $\quad$ Britton (c. 1290); 9

\footnotetext{
${ }^{1}$ GSMcBain, Modernising the Law on Escape, Prison Breach and Rescue (2014) Review of European Studies, vol 6, no 4, pp 147-73.

2 From early times, 'imprisonment' was conceived as a double legal act. It involved: (a) arrest; and (b) detention. See Bracton, text to n 54 .

${ }^{3}$ Headboroughs (also called borseholders) as well as other local police constables are now obsolete.

${ }^{4}$ W Archbold, Criminal Pleading, Evidence and Practice (Sweet \& Maxwell, 2014), para 19-337. 'Both kidnapping and false imprisonment are common law offences, punishable by a fine or imprisonment, or both. Both are specified violent offences within Schedule 15 to the CJA [Criminal Justice Act] 2003.'

${ }^{5}$ See eg. Anglo-Norman dictionary (online, anglo-norman.net), definition of 'faux' (in law) 'unrightful, not reflecting the truth'. See also definition of 'emprisonement' (imprisonment) and references to 'bref de (faux) emprisonement' (a writ charging illegal imprisonment).

${ }^{6}$ This will also enable it to dovetail better with escape etc, since the courts have analysed 'custody' and 'lawful custody' in detail. See n 1.

${ }^{7}$ See $n 1$.

${ }^{8} \mathrm{H}$ Bracton (trans Thorne), On the Law and Customs of England c.1240 (Cambridge UP, 1968-76). Bracton is now online, see bracton.law.harvard.edu
} 
- Fleta (c. 1290); ${ }^{10}$

- The Mirror of Justices (c. 1290); ${ }^{11}$

- $\quad$ W Staunford, Les Plees del Coron $\left(1^{\mathrm{st}} \mathrm{ed}, 1557\right) ;^{12}$

- W Lambard, Eirenarcha or of the Office of the Justices of Peace (1581); ${ }^{13}$

- A Fitzherbert, The Newe Boke of Justices of the Peas (1538); ${ }^{14}$

- $\quad$ F Pulton, De Pace Regis et Regni ( $\left.1^{\mathrm{st}} \mathrm{ed}, 1609\right) ;{ }^{15}$

- $\quad$ M Dalton, The Countrey Justice (1618-1746); ${ }^{16}$

- $\quad$ E Coke, Institutes of the Laws of England (1628-41); ${ }^{17}$

- W Hawkins, A Treatise of the Pleas of the Crown (1716-1824); ${ }^{18}$

- M Hale, The History of the Pleas of the Crown (published 1736, written 1640's); ${ }^{19}$

- W Blackstone, Commentaries on the Laws of England (1765-9); ${ }^{20}$

- W Archbold, Criminal Pleading, Evidence and Practice (1822-2014); ${ }^{21}$

- Halsbury, Laws of England. ${ }^{22}$

Apart from Archbold, Halsbury and Blackstone's Criminal Practice, ${ }^{23}$ modern criminal texts contain some analysis of this common law crime. ${ }^{24}$ Finally, of use are various Abridgments, major and minor, viz.

- N Statham, Abridgment of the Law (c. 1490); ${ }^{25}$

- A Fitzherbert, La Graunde Abridgment ( $3^{\text {rd }}$ ed, 1577); ${ }^{26}$

- $\quad$ R Brooke, La Graunde Abridgment (1586); ${ }^{27}$

${ }^{9}$ FM Nichols (ed), Britton (John Byrne \& Co, 1901).

${ }^{10}$ Fleta, see Selden Society ('SS'), vols 72, 89 \& 99.

11 The Mirror of Justices, SS, vol 7, p 52, ch 9 (of Gaol and Gaolers).

${ }^{12}$ W Staunford, Les Plees del Coron (Richard Tottell, 1557, $2^{\text {nd }}$ ed 1607).

${ }^{13}$ W Lambard, Eirenarcha, or of the Office of the Justices of Peace (1581, rep Law Book Exchange).

${ }^{14}$ See also A Fitzherbert, The Newe Boke of Justices of the Peas (London, 1538). His text was later enlarged by R Crompton, see A Fitzherbert \& R Crompton, L'Office et Auchtoritie de Justices de Peace (1584, rep Professional Books Ltd, 1972). See also R Burn, Justice of the Peace and Parish Officer $\left(1^{\text {st }}\right.$ ed, $1755,23^{\text {rd }}$ ed, $1820,30^{\text {th }}$ ed (last), 1869).

${ }^{15}$ F Pulton, De Pace Regis et Regni (1st ed, 1609, rep Professional Books Ltd).

${ }^{16}$ M Dalton, The Countrey Justice (London, printed for the Society of Stationers, corrected ed, 1619).

${ }^{17}$ E Coke, Institutes of the Laws of England (W Clarke \& Sons, London, last ed, 1824).

${ }^{18}$ W Hawkins, A Treatise on Pleas of the Crown (E \& R Nutt \& R Gosling, Savoy (3rd ed, 1739)). The $1^{\text {st }}$ edition of Hawkins was in $1716-21$, the last (the $8^{\text {th }}$ ed) in 1824 .

${ }^{19} \mathrm{M}$ Hale, The History of the Pleas of the Crown (printed for E \& R Nutt \& R Gosling, 1736).

${ }^{20}$ W Blackstone, Commentaries on the Laws of England (Oxford, Clarendon Press, $1^{\text {st }}$ ed, 1765-9, University of Chicago Press rep 1979) .

${ }^{21}$ See Archbold, $\mathrm{n} 4$. See also, JF Archbold, A Summary of the law relative to Pleading and Evidence in Criminal Cases (London, 1822 , being the $1^{\text {st }}$ ed).

${ }^{22}$ Halsbury, Laws of England (5th ed, with updates).

${ }^{23}$ Blackstone's Criminal Practice 2013 (eds A Hooper \& D Ormerod)('Blackstone CP'). See also Archbold, Magistrates Courts Criminal Procedure ('Archbold Procedure').

${ }^{24}$ See, for example: (a) C McAlhone \& R Huxley-Binns, Criminal Law. The Fundamentals (3rd ed, 2013); (b) MJ Allen, Textbook on Criminal Law (12 ${ }^{\text {th }}$ ed, 2013); (c) A Ashworth \& J Horder, Principles of Criminal Law (7 ${ }^{\text {th }}$ ed, 2013); (d) R Card et al, Criminal Law (20 ${ }^{\text {th }}$ ed, 2012); (e) CMV Clarkson \& HM Keating, Criminal Law, Text and Materials ( $7^{\text {th }}$ ed, 2010); (f) C Elliott \& F Quinn, Criminal Law ( $8^{\text {th }}$ ed, 2010); (g) R Heaton, Criminal Law (2 ${ }^{\text {nd }}$ ed, 2006); (h) J Herring, Criminal Law ( $8^{\text {th }}$ ed, 2013); (i) M Jefferson, Criminal Law (9 ${ }^{\text {th }}$ ed, 2009); (j) Lacey, Wells \& Quick, Reconstructing Criminal Law. Text and Materials ( $\left.4^{\text {th }} \mathrm{ed}, 2010\right)$; (k) J Loveless, Complete Criminal Law. Text. Cases and Materials $\left(3^{\text {rd }}\right.$ ed, 2012); (1) N Padfield, Criminal Law ( $7^{\text {th }}$ ed, 2010); (m) A Reed \& B Fitzpatrick, Criminal Law (4 ${ }^{\text {th }}$ ed, 2009); (n) AP Simester, Simester $\&$ Sullivan's Criminal Law: Theory and Doctrine ( $\left.5^{\text {th }} \mathrm{ed}, 2013\right)$; (o) D Ormerod, Smith \& Hogan's Criminal Law (13 ${ }^{\text {th }}$ ed, 2011); (p) DJ Baker, Glanville Williams Textbook of Criminal Law ( $\left.3^{\text {rd }} \mathrm{ed}, 2012\right)$; (q) MJ Allen \& S Cooper, Elliott \& Woods' Cases and Materials on Criminal Law $\left(11^{\text {th }} \mathrm{ed}, 2013\right)$; (r) M Molan, Cases and Materials on Criminal Law (4 ${ }^{\text {th }}$ ed, 2008); (s) J Martin \& T Storey, Unlocking Criminal Law (3 ${ }^{\text {rd }}$ ed, 2010); (t) P Hungerford-Welch \& A Taylor, Sourcebook on Criminal Law (1997); (u) M Molan et al, Bloy \& Parry's Principles of Criminal Law ( $4^{\text {th }}$ ed, 2000); (v) W Wilson, Criminal Law $\left(4^{\text {th }}\right.$ ed, 2011). For older $20^{\text {th }}$ century texts, see JW Cecil Turner, Kenny's Outlines of Criminal Law $\left(19^{\text {th }}\right.$ ed, 1966) and R Cross \& PA Jones, An Introduction to Criminal Law (2 ${ }^{\text {nd }}$ ed, 1949).

${ }^{25}$ N Statham, Abridgment of the Law (Pynson, c. 1490). This has been reprinted by the Law Book Exchange. For a translation, see MC Klingelsmith, Statham's Abridgment of the Law (Boston Book Company, 1915).

${ }^{26}$ A Fitzherbert, La Graunde Abridgment (Tottell, $3^{\text {rd }}$ ed, 1577). This has been reprinted by the Law Book Exchange. 
- H Rolle, Abridgment des plusieurs Cases et Resolutions del Common Ley (1668), ${ }^{28}$

- W Hughes, Grand Abridgment of the Law (1660-3), ${ }^{29}$

- W Sheppard, Grand Abridgment of the Common and Statute Law of England (1675); ${ }^{30}$

- W Nelson, Abridgment of the Common Law (1725-6); ${ }^{31}$

- $\quad$ M Bacon, New Abridgment of the Law ( $5^{\text {th }}$ ed, 1798); ${ }^{32}$

- $\quad$ E Viner, A General Abridgment of the Law and Equity $\left(1^{\text {st }}\right.$ ed, 1741-57); ${ }^{33}$

- J Comyns, Digest of the Laws of England (last ed, 1822). ${ }^{34}$

\section{Prisons in Early Medieval Times}

\section{(a) Imprisonment - Nature of Prisons}

As noted in a previous article ${ }^{35}$ prisons - the word derives from the medieval latin prisio, ${ }^{36}$ meaning to arrest are ancient in being and, in the case of England, they likely existed in Anglo-Saxon times. ${ }^{37}$ William I (1066-87) built the first royal prison - the Tower of London - which was likely used as such from 1100. There were also other London prisons such as the Fleet (built 1197), Newgate (established 1188) and Ludgate (established c. 1215). As well as 'royal prisons', ${ }^{38}$ there were also, from early times, local prisons the franchise ${ }^{39}$ of which was granted to important barons, ecclesiastics, boroughs, towns and palatinates etc. As to these two types of prison - the Mirror of Justices (written c. 1290) - states:

There be two kinds of prison, common and private...Every common prison is a gaol, and only the king has the keeping of it. Every other man's prison is private... ${ }^{40}$

Unlike today - apart from the main London prisons - prisons were very much 'ad hoc' affairs, being often little more than cellars (dungeons) or a room in a castle. Further, it was (generally) unusual in early medieval times to imprison a person. This was regarded a bad option, economically, since it imposed a financial obligation on the Crown (recouped, to a limited extent by the prisoners paying for their food and accommodation which was used to defray, among other things, the salary of their jailers). ${ }^{41}$ In conclusion, prisons in medieval times comprised a

${ }^{27}$ R Brooke, La Graunde Abridgment (Tottell, 1586).

${ }^{28}$ H Rolle, Abridgment des plusieurs Cases et Resolutions del Common Ley (A Crooke et al, 1668).

${ }^{29}$ W Hughes, Grand Abridgment of the Law (Henry Twyford etc al, 1660-3). This has been reprinted by the Law Book Exchange.

${ }^{30}$ W Sheppard, Grand Abridgment of the Common and Statute Law of England (sold by George Sawbridge et al, 1765).

${ }^{31}$ W Nelson, Abridgment of the Common Law (E \& R Gosling, 1725-6). This has been reprinted.

${ }^{32}$ M Bacon, New Abridgment of the Law (H Gwillim (ed), $5^{\text {th }}$ ed, 1798).

${ }^{33}$ E Viner, A General Abridgment of the Law and Equity (GCJ \& J Robinson, $1^{\text {st }}$ ed, 1741-57, $2^{\text {nd }}$ ed 1791). This has been reprinted by the Law Book Exchange (there is also a CD with wordsearch).

34 J Comyns, Digest of the Laws of England (A Hammond, last ed, 1822). See also J Lilley, Practical Register (2 ${ }^{\text {nd }}$ ed, 1765).

35 See McBain, $\mathrm{n} 1$.

${ }^{36}$ Classical latin used 'carcer' to refer to a prison. See Lewis and Short, Latin Dictionary (Oxford, Clarendon Press, $1^{\text {st }}$ ed, 1879). The Oxford English Dictionary ('OED') (definition of prison) speculates that 'prisio' (old French) derived from a reference to a person being taken in war as a 'prise' or 'prize.' Prison, therefore, connoted some forcible deprivation of personal liberty, being kept in captivity, detained in custody etc. It also became a reference to any place where such confinement ensued. N Morris \& DJ Rothman, The Oxford History of the Prison (NY, 1998), p 35 'In Old French the latin term prisio, derived from a latin term meaning 'to arrest' or 'to take custody of', acquired a variety of distinct meanings. It might mean the act of arrest, the right to try someone arrested, the right to arrest a free person, the state of privation of liberty, or the actual place of detention itself. In French, Italian, and English it displaced the older and more formal latin term carcer and the medieval latin term geola, which became, in English, 'jail'.'

${ }^{37}$ RB Pugh, Imprisonment in Medieval England (Cambridge UP, 1968), ch 1, p 1 'Imprisonment in England has no connected history before the end of the twelfth century. Its origins, however, are antique and stretch back before the days of Alfred [ie. Alfred the Great, king of Wessex, 871-99]. Once private jurisdictions begin to emerge, and this was perhaps in the eighth century, some kind of 'prison' may be presumed to exist.' Also, 'In Alfred's time the word 'prison' (carcerr) first makes its appearance in a code of laws (c. 890).' See generally, McBain, $\mathrm{n} 1$.

${ }^{38}$ Ibid, p 87 'According to the doctrine that eventually prevailed, all prisons, or at any rate all prisons outside the palatinates, were the king's. They were his because they were ancillary to his justice.' Coke, n 17, vol 2, p 589 'Albeit divers lords of liberties have custody of the prisons, and some in fee, yet the prison itself is the king's pro bono publico:...f for no subject can have the prison itself, but the king only...' (spelling modernised). See also McBain, $\mathrm{n} 1$.

${ }^{39}$ Ibid, p 87 'By the late thirteenth century, if not before, the word 'prison' (prisona) had acquired a very extensive meaning. It could be applied to a county gaol maintained by a sheriff...to one of the few 'national' prisons, or to a franchise gaol owned by the lord of a liberty. The third of these classes is naturally a very broad one, for it comprises prisons owned by leading ecclesiastics and lay barons and also those in borough ownership.'

${ }^{40}$ See, n 11, p 52.

41 See $n 1$. 
last resort for severe crimes (such as treasons or homicide) ${ }^{42}$ or in lieu of the prisoner failing to pay an amercement or fine. 43

\section{(b) Franchise Prisons}

In early medieval times - especially prior to 1215 , when the law was often ignored and there were great struggles between the Crown and powerful barons - it is clear that many franchise prisons were often utilized as places of oppression. Pugh states:

there is no doubt that the Normans found a number of prisons in the England that they invaded, particularly upon royal manors in the south and, in effect, they added to their number. They did this by building many castles in which both king and barons shut up their powerful adversaries and during the Anarchy [1135-53] very many of the common people also. ${ }^{44}$

As to these franchise prisons:

- $\quad$ On ascending the throne, Henry II (1154-89) ordered the destruction of many adulterine (unauthorized) castles, which would have contained prisons ${ }^{45}$ and - in the Assizes of Clarendon in 1166 - he commanded his sheriffs to build prisons in each county where they did not previously exist in order to hold those accused of felonies until they could be tried by justices in eyre. Many towns were ordered to do the same; ${ }^{46}$

- Although such steps diminished the number of franchise prisons, many would have remained. Indeed, some prisons by way of franchise continued until the $19^{\text {th }}$ century. ${ }^{47}$

\section{(c) Oppressive Use of Prisons}

In early medieval times the sovereign, sheriffs ${ }^{48}$ and powerful magnates often imprisoned innocent persons to secure the re-payment of debts, for political purposes or to extort money. ${ }^{49}$ Thus, for example, an Act of 1403

42 eg. Bracton, n 8, p 349 (writing c 1240) 'In every injuria and trespass against the king's peace to which the word 'felony' is added, the appellee or person accused is usually released by pledges, except in the case of homicide, since no one who can provide pledges is to be thrust into prison unless it is evident that he has perpetrated so serious a crime that he ought not to be handed over either to sureties or soldiers but suffer the penalty of imprisonment and confinement...'. See also Mirror, n 11, p 23 'Into the common prison [ie. the king's prisons] no one is to be put if not attainted, appealed as a principal, or indicted for mortal sin [ie. a felony], or by judgment for false or tortious imprisonment.' Also, p 160.

${ }^{43}$ See McBain, n 1. See also F Pollock \& FW Maitland, The History of English Law before the time of Edward I (Cambridge UP, $2^{\text {nd }}$ ed, 1898 , rep 1968) ('P \& M'), pp 516-7 re the development of prisons and how the threat of imprisonment was utilised as a means of securing a fine. At p 517 'Now, so far as we can see, the justices of Henry III's reign [1216-72] used their power of imprisonment chiefly as a means of inflicting pecuniary penalties. The wrong doer but rarely goes to prison even for a moment.'

44 The 'Anarchy' describes the chaotic reign of king Stephen (1135-54). See generally, GSMcBain, Expanding Democracy - Transferring the Crown Prerogative to Parliament (2014) Rev. of European Studies, vol 6, no 1, pp 34-5 (Crown prerogative to build a military castle or fortress). Also, J Bradbury, Stephen and Matilda: The Civil War of 1139-53 (Stroud, UK. The History Press).

45 J Selden, England's Epinomis (1683), p 20 'His [Henry II's ] first care tending wholly to the good of the State, was to have the numerous increase of castles and forts....abated; so was it by express command performed and the laws of his grandfather...likewise confirmed.' The latter reference would seem to be to the laws of Henry I [1100-35] c. 1113 which provided that 'The following place a man in the king's mercy....construction of fortifications without permission [castellatio sine licencia]'. See McBain, n 44, p 34 and LJ Downer, Leges Henrici Primi (OUP, 1972), p 117.

${ }^{46} \mathrm{~A}$ translation of the relevant wording in the Assize of Clarendon 1166 is: 'And in the several counties where there are no jails, let them be made in a borough or in some castle of the king...to the end that the sheriffs may keep in them those who have been arrested by the officers whose function it is to do this and by their servants.' See also Pugh, n 37, pp 4 \& 59; C Harding et al, Imprisonment in England and Wales (Croom Helm, 1985), p 5 and JF Stephen, A History of the Criminal Law of England (Macmillan, 1883), pp 483-4.

${ }^{47}$ Harding, n 46, p 18 'Franchise prisons were known as late as the nineteenth century but in reality, save for a few liberties held by ecclesiastics, their heyday had been in the early Middle Ages.'

${ }^{48}$ Sheriffs were a byword for corruption in early medieval times. See GSMcBain, Abolishing Obsolete Offices (2012) Coventry LJ, vol 17, no 2, pp 31-40 (discusses the early history of sheriffs). Britton (c. 1290), n 9, p 74 '[Let inquiry be made at the Eyre] if any sheriff through malice has kept any man in prison whom he ought to have brought before our justices at our gaol delivery, and in this case [he is] to be punished by fine and imprisonment.'

${ }^{49}$ Blackstone - adopting a rather rosy view of early medieval history - considered that a personal liberty of the subject generally prevailed from the time of William I (1066-87), subject to exceptions. However, a more detailed review of history pre-Henry VII (1485-1509), and even after that, suggests that it was often impossible to prevent subjects being arbitrarily imprisoned (at the command of the sovereign or powerful nobles) on many occasions. Blackstone, n 20, vol 3, p 133 stated: 'In a former part of these commentaries we expiated at large on the personal liberty of the subject. It was shown to be a natural inherent right, which could not be surrendered or forfeited unless by the commission of some great and atrocious crime, nor ought to be abridged in any case without the special permission of law. A doctrine co-eval with the first rudiments of the English constitution; and handed down to us from our Saxon ancestors, notwithstanding all the struggles with the Danes, and the violence of the Norman conquest: asserted afterwards and confirmed by the conqueror himself [ie. William I] and his descendents: and though sometimes a 
noted:

divers constables of castles within the realm, being assigned justices of peace by the king's commission, had by colour of such commission used to take people to whom they bore evil will, and imprisoned them within the said castles till they had made fine and ransom with the said constables for their deliverance, thereupon it is enacted, that none be imprisoned by any justice of the peace but only in the common gaol, saving to lords and others, which have gaols, their franchise in this case. ${ }^{50}$

Given this, it is noticeable that 'false' - that is, unlawful imprisonment - was recognized as a crime early on in the common law. It was also held to be a civil offence. Thus, a person unlawfully imprisoned had the option of either recovering damages against his oppressor or having him prosecuted criminally - the punishment being a fine or imprisonment. This is now discussed.

In conclusion, in early medieval times, prisons - especially franchise prisons - were often mis-used. Therefore, it is not surprising that a crime of false imprisonment developed.

\section{False Imprisonment: 1240-90}

Bracton, On the Laws and Customs of England, written c. 1240, referred to a writ of odio and atia by which a person falsely imprisoned might secure his freedom. ${ }^{51}$ He stated:

since it is iniquitous that the innocent as well as the guilty be kept in prison for a long time, therefore, at the doleful plaint of kinsmen and friends and by the grace of the lord king, an inquest is ordinarily made as to whether such persons imprisoned for homicide were guilty of the said death or not, that is, whether they were appealed because of hate and spite. No one ought to be denied a writ for an inquest of this kind ${ }^{52}$... When the inquest finds that the prisoner has been appealed because of hate and spite, not because of guilt, let him then be released on bail by order of the lord king, by a writ directed to the sheriff in this form..., 53

Later on in the text, Bracton stated:

We have spoken above of beach of the peace ['BOTP'] wounding and mayhem. Now we must speak of [BOTP] and imprisonment, where a free man has been arrested and imprisoned against the peace in the court [of a lord], as within someone's liberty [or in] a city, vill or borough, [that is], shut up in a house or castle and detained against the peace in irons, fetters or the stocks until released by the king's serjeant or his writ, after he has been refused bail. One may here commit a double offence, the first by the wrongful arrest, a second by the wrongful detention...

In an appeal of BOTP ${ }^{55}$ and wounding and imprisonment, though the deed is criminal, the suit may be brought civilly, as where one says, as though complaining of an injuria, and without adding words of felony, that such a one imprisoned such a one against the peace of the lord of that court, or if the complaint is in a city, vill, or borough, against the peace of the lords and the peace of the bailiffs, [or] if it is in the county court, against the sheriff's peace... No corporal punishment then follows, only a

little impaired by the ferocity of the times, and the occasional despotism of jealous or usurping princes, yet established on the firmest basis by the provisions of Magna Carta, and a long succession of statutes enacted under Edward III [1327-77].'

505 Hen 4 c 10 (rep).

${ }^{51}$ Blackstone (writing in 1769), n 20, vol 3, pp 218-9 says of this writ: 'The writ de odio et atia was anciently used to be directed to the sheriff, commanding him to enquire whether a prisoner charged with murder was committed upon just cause of suspicion, or merely propter odium et atiam, for hatred and ill-will; and, if upon the inquisition due cause of suspicion did not appear, then there was issued another writ for the sheriff to admit him to bail. This writ, according to Bracton, ought not to be denied to any man; it being expressly ordered to be made out gratis, without any denial, by Magna Carta, c 26 and statute Westm. 2. 13 Edw I c 29 [1285]. But the statute of Glocester, 6 Edw I c 9 [1278] restrained it in the case of killing by mis-adventure or self-defence, and the statute 28 Edw III c 9 [1354] abolished it in all cases whatsoever: but as the statute 42 Edw III c 1 [1368] repealed all statutes then in being, contrary to the great charter, sir Edward Coke is of opinion that the writ de otio et atia was thereby revived.' The citation is to Coke, $\mathrm{n} \mathrm{17,} \mathrm{vol} \mathrm{2,} \mathrm{pp} \mathrm{43,} 55$ \& 315.

${ }^{52}$ Bracton, $\mathrm{n} 8$, vol 2, pp 346-7. He continues 'The form of the writ is this [The writ for holding an inquest as to whether they were appealed because of hate and spite]: 'The king to the sheriff, greeting. We order you to inquire carefully by responsible and law-worthy men of your county into whether A of N, arrested and detained in our prison of such a place for the death of B, of which he was accused (or 'appealed') was accused (or 'appealed') of that death because of hate and spite or because he is guilty thereof. And if because of hate and spite, because of what hate and what spite and who is guilty thereof. And the inquest you make thereon etc.'

53 Ibid. Bracton then sets out various writs, including that for a clerk.

${ }^{54}$ Ibid, p 410. Bracton then sets out the words of the appeal, denial, exceptions etc.

55 The headnote inserted into the text states 'This appeal may be sued civilly or criminally, with or without the assignment of felony, [and] depending on the words of the appeal a [corporal] punishment, or [a pecuniary penalty] according to the seriousness of the offence follows.' 
pecuniary penalty by way of damages, which would be otherwise if felony were assigned, where the inquest is a matter for the king alone, because life and members are placed in jeopardy, because no one may judge as to that except the king. Justice belongs to no one except the king, nor does imprisonment, nor will anyone have his court thereof unless he enjoys a special liberty [ie. a franchise] from the king himself... 56

The analysis of Bracton is useful.

- False imprisonment is a crime because it is a BOTP. ${ }^{57}$ Further, imprisonment was legally perceived to be a double crime - one of wrongful arrest and another of wrongful detention;

- Bracton also notes there were two remedies for false imprisonment, at the option of the victim. He might secure damages by way of a civil remedy or he might seek the imprisonment (or fining) of the perpetrator. $^{58}$

The text, Fleta, written c. 1290, follows Bracton fairly closely. It states:

Since many of those who are imprisoned are free and innocent of the crimes charged against them, and it would be hard if such men were unjustly [iniuste] detained in gaol, it is enacted that a remedy shall be available to them. If on a writ de odio et atia the enquiry is made in open county court by the sheriff and coroner and the reason for the enmity or hatred is stated in the inquisition sent to the king or his chancellor, and if on examination it is found that the reason stated is evidently true and not misrepresented by the sheriff, who sometimes is moved by favour to allege a reason that does not exist, then a writ shall issue stating that if so-and-so lying in gaol find twelve sufficient pledges that he will stand his trial whenever the king or another shall wish to proceed against him for the death of such a one, then the sheriff shall bail him to the twelve mainpernors aforesaid or discharge him on bail from the aforesaid prison, provided that no suit save the king's is involved. If, however, the [alleged] reason for the enmity is inadequate, he shall not have a writ of discharge. ...

And when the prisoner is freed and released on bail, he shall have a right of action for imprisonment and breach of the king's peace against all those who have detained him in prison since the arrival of the first order from the king... 59

An appeal of imprisonment may be made in this case, namely, where a freeman is taken and imprisoned against the king's peace. Imprisonment involves a double offence, unlawful arrest and unlawful detention, ${ }^{60}$ in fetters or without, in stocks or with some other punishment, greater or less ${ }^{61} \ldots$ In [this appeal of] imprisonment, it is open to the plaintiff to proceed by way of a civil action, complaining of a wrong by writ of trespass, ${ }^{62}$ or by way of a criminal action. The sentence for unlawful imprisonment is imprisonment, with fetters or the like as a punishment, according to the treatment the plaintiff has suffered, nor should delivery therefrom ensue until adequate satisfaction has been made to the injured

\footnotetext{
${ }^{56}$ Bracton, n 8, vol 2, pp 411-2.

${ }^{57}$ That is, it will produce violence since a person unlawfully detained will seek to escape or, at least, there is the threat of the same. Lambard (writing in 1581), n 13, p 135 'if a man do imprison an other without warrant... he has broken the peace.' (spelling modernised).

${ }^{58}$ In the case of powerful magnates, the court would be unlikely to wish (or be able) to seek their imprisonment. Therefore, a civil option would likely be promoted. See for the position in part of France (county of Clermont in 1283), FRP Akehurst (trans), The Coutumes de Beauvasis of Phillipe de Beaumanoir (1283)(Univ of Pennsylvania Press, 1992), p 563 'The officer who knowingly makes a wrongful arrest, or makes one where he should not, in order to cause loss without a good reason, must on conviction pay for all the damages to the person whose property was seized, and must lose his job as an officer, for he performed it dishonestly.'

${ }^{59}$ Fleta, n 10, vol 72, pp 67-8.

${ }^{60}$ Later, imprisonment tended to be distinguished from arrest as such. Lambard (writing in 1581), n 13, p 102 defined arrest as follows: 'An arrest is a certain restraint of a man's person, depriving it of his own will and liberty, and binding it to become obedient to the will of the law: and it may be called the beginning of imprisonment.'

${ }^{61} \mathrm{He}$ continues 'The appeal is in this fashion: A appeals B that, whereas he was [in the king's peace] etc, the said B came with force etc and arrested him wickedly and led him to such a place and there detained and imprisoned him and put him in stocks (or in irons or fetters or the like) and detained him in this manner from such a day to such a day against gages and pledges (or until the said A gave him so much for his ransom or until he was set free by the king's writ). And that he did this wickedly and feloniously, he offers to prove by his body as the king's court shall award.'

${ }^{62}$ RC Palmer, English Law in the Age of the Black Death 1348-1381 (Univ. North Carolina Press, 1993), p 155 'Trespass writs returnable into the king's court had grown quite varied by the 1320s. General returnable writs of trespass included writs for...false imprisonment...'
} 
party for the damages awarded and to the king for a heavy ransom. ${ }^{63}$

In conclusion, by the time Bracton wrote (c. 1240), and likely considerably before, ${ }^{64}$ an offence of false (illegal) imprisonment was recognised.

\section{False Imprisonment: 1290-1600}

In early times, the persons likely to be accused of false imprisonment were sheriffs and their underlings, such as deputy sheriffs and bailiffs. However, there were also thithingmen and headboroughs (also called borsholders) who performed minor judicial functions in the criminal sphere. And, from 1285, if not before, there were constables - high and petty. Illegal detention by any of these gave rise to a criminal offence. As to the nature of these law enforcers:

\section{(a) Police Functions - Sheriffs}

In early times, the high sheriff (usually fore-shortened to 'sheriff') was particularly powerful. ${ }^{65}$

- The office of 'shire reeve' (scir gerefa) or sheriff is old and it existed in Anglo-Saxon times. It continued in Norman times - albeit it was then a Crown appointment whereas, previously, it may have been elected;

- As well as having tax gathering functions, the sheriff executed writs and judged cases (criminal and civil) in the shire. He usually employed deputy sheriffs (also called under, or secondary, sheriffs) as well as bailiffs and jailers to carry out his legal functions, which included arrest and imprisonment; ${ }^{66}$

- In early medieval times, sheriffs were reviled for their oppressive and extortionate conduct and Magna Carta 1215 initiated the process of reducing their judicial power while extending that of the king's courts; ${ }^{67}$

- The role of the sheriff diminished further with the establishment of Conservators of the Peace in 1328 who later became Justices of the Peace ('JP's'). ${ }^{68}$ The latter were subsequently given increased judicial powers both pursuant to their commission from the Crown and as a result of legislation - such as the Justice of the Peace Act 1361 (still extant).

In conclusion, in early times, the king's officers responsible for the arrest and detention of persons - as well as their imprisonment - mainly comprised high sheriffs and their underlings.

\section{(b) Police Functions - Constables}

As well as the high sheriff and his underlings being responsible for the arrest and imprisonment of persons in early times, there were constables. Bellamy ${ }^{69}$ summarises the position:

The medieval constable was a local police officer and the official with whom most criminals came into contact in the first instance. There were constables of the township and constables of the hundred. Both types were elected to office yearly. Constables of the township, either two or three in number, had to make the arrest when hue and cry had been raised... When the township constable had captured the miscreant...he kept him in custody until he could be handed over to the sheriff or his bailiff. The constable was expected to arrest those who carried weapons at fairs and markets and the misdoers whom the Statute of Winchester (1285) called 'roberdesmen and drawlatches'. On the orders of the sheriff or the coroner, the constable arrested men who had been appealed or indicted. Sometimes he was set to guard men arrested by the sheriff's bailiff or the bailiff of a franchise. For this purpose he might use the

\footnotetext{
${ }^{63}$ Fleta, $\mathrm{n} 10$, vol 72, pp 98-9. See also the Mirror, n 11, p 132 'imprisonment [enprisonement] as a punishment for false imprisonment'. It also noted that false imprisonment (like mayhem and wounding) was a crime which merited retaliatory punishment. Ibid, p 142 'we speak of retaliatory punishments...imprisonment for imprisonment.'

${ }^{64}$ The earliest legal text, Glanvill, did not deal with this offence. See R Glanvill (trans G Hall), Treatise on the Laws and Customs of the Realm (Oxford UP, c. 1189), ch 14 (Criminal Pleas).

${ }^{65}$ See McBain, $\mathrm{n} 48$.

${ }^{66}$ Lords of the manor could secure a franchise to hold a court leet (as opposed to the sheriff's tourn) to handle minor criminal matters and nuisances. The court leet was also called the view of frankpledge or law day. See also 'A Statute for View of Frankpledge' (c. 1325).

${ }^{67}$ Magna Carta, ch 24 provided that 'no sheriff, constable, coroners, or others of our bailiffs, shall hold pleas of our Crown.' DM Walker, The Oxford Companion to Law (Oxford, 1980) (definition of sheriff) 'from the mid-twelfth century, his growth was limited by the growth of the king's courts and he came to have the functions of conducting preliminary investigations of accused persons, trying minor offences and detaining greater offenders till the itinerant justices came.'

${ }^{68}$ See also WLM Lee, History of the Police in England ( $1^{\text {st }}$ ed, 1901), p 44 et seq.

${ }^{69} \mathrm{~J}$ Bellamy, Crime and Public Order in England in the Later Middle Ages (Routledge, 1973).
} 
stocks. He was also expected to maintain a watch on the property of fugitive felons and of those men who were in custody.

The constable of the hundred, in contrast, very nearly had historical importance thrust upon him. The office had a semi-military character, for the hundred constables were the permanent captains of the hundred posses. They were expected to see that the statutory requirements about the arms to be possessed by each man were obeyed, and in addition they had to present before the justices any failure to keep watch, to clear the highway, or to follow the hue and cry. There were occasions when they received indictments concerning breaches in the Statute of Winchester, but they were never empowered to enquire into felonies, or trespasses in general. Eventually, having for a period in the early fourteenth century been unconscious rivals with the keepers of the peace for the prize of being a local justiciar, they passed into oblivion.

Both types of constable received many of their instructions from the sheriff, but his closest servants were the men who executed royal writs, the itinerant bailiff and the hundred bailiff. Since both were normally appointed by the king, royal approval was necessary if they were to be replaced. Their duties included making attachments, arrests, and distraints, but, in addition to such shrieval business, they purveyed food and animals for royal use, and even helped to collect subsidies. In some places they held the hundred court and the sheriff's tourn. The hundred bailiff acquired a reputation for extortion by threatening to arrest people arbitrarily, impounding beasts wrongfully, and letting men off army and jury service.'(italics supplied $)^{70}$

In conclusion, constables comprised petty constables and high constables. Both were responsible to the sheriff.

\section{(c) When Police Constables Originated: 1327, 1285 or 1242 ?}

When constables - high and petty - first appeared on the legal scene, is unclear. ${ }^{71}$ Hawkins, in the first edition of his Pleas of the Crown in 1716, stated:

as to the antiquity of the office of a constable, it seems to be the better opinion, that both constables of hundreds, which are commonly called high constables, and also constables of tythings, which are at this day commonly called petit constables or tythingmen, and which are anciently called chief pledges, were by the common law, and not first ordained by the Statute of Winchester [Statutum Wynton, 1285], cap 6 as it is holden by some that they were; for that statute doth not say, that there shall be such officers constituted, but seems clearly to suppose that there were such before the making of it. ${ }^{72}$

Others, such as Coke ${ }^{73}$ and Blackstone ${ }^{74}$ asserted that high constables originated from the Statute of Winchester 1285, chapter 6 of which provided:

That every man have in his house harness for to keep the peace after the ancient assize; that is to say, every man between fifteen years of age, and sixty years...And that view of armour be made every year two times. And in every hundred and franchise two constables [conestables] shall be chosen to make view of armour... ${ }^{75}$

However, the earlier Statute of Westminster 1275, chapter 7 also refers to constables, although this may relate to military constables or castellians only. It states:

no constable, nor castellain, from henceforth [shall] exact any prise, or like thing of any other than of

\footnotetext{
${ }^{70}$ At pp 93-4.

${ }^{71}$ For a useful text see Lee, $\mathrm{n} 68$. For early texts on constables, borsholders, tythingmen, headboroughs, bailiffs etc see texts cited in Sweet \& Maxwell, A Legal Bibliography of the British Commonwealth (2 $2^{\text {nd }}$ ed, 1955, 2 vols), especially, vol 1, pp 233-6. See, in particular, (a) G Jacob, Compleat Parish-Officer (1 $1^{\text {st }}$ ed, 1718); (b) W Lambard, Dueties of Constables, Borsholders, Tything-men and such other lowe and lay Ministers of the Peace $\left(1^{\text {st }}\right.$ ed 1582, $8^{\text {th }}$ ed 1599); (c) J Ritson, Office of Constable $\left(1^{\text {st }}\right.$ ed, 1791); (d) W Sheppard, Office and Duty of Constables, Borsholders, Tythingmen etc ( $1^{\text {st }}$ ed 1655); (e) R Turner, The Duty and Office of High Constables of Hundreds, Petty Constables, Tything Men, and such inferiour Ministers of the Peace (1761). See also HB Simpson, The Office of Constable (1895), English Historical Review, vol 10, pp $625-41$.

${ }^{72}$ Hawkins, n 18, bk 2, ch 10, s 33, p 61 (repeated in the final edition in 1824).

${ }^{73}$ Coke, n 17, vol 4, p 267 'There are constables of the hundred commonly called chief constables, so named, because constables of towns are called petit constables. These constables of hundreds were created by the statute of 13 E 1 [ie. the Statute of Westminster 1285]...' See also Dalton, n 16, p 39.

${ }^{74}$ Blackstone, n 20, vol 2, p 344.

${ }^{75} 13$ Edw 1 st 2 c 6 (confirmed a number of times, see eg. 28 Edw 1 c 17, 28 Edw 3 c 11 and 7 Ric 2 c 6).
} 
such as be of their town or castle 76

There is also an oft cited writ of 1242 (oft mis-stated as being of 1252) ${ }^{77}$ which refers to the employment of constables in parishes and towns for enforcing watch and ward. ${ }^{78}$ However, this may refer to petty, as opposed to high, constables. ${ }^{79}$ That said, even before 1242, there must have been some form of local police officer and this may have arisen from hereditary sarjeanties ${ }^{80}$ as well as the role being, effectively, undertaken by those responsible for administering the system of frankpledge - that is headboroughs (tithingmen). As to the etymology of the word 'constable', this is also uncertain and has led to speculation. It seems to have been Anglo-Norman as opposed to Anglo-Saxon ${ }^{81}$ and may have come from comes- stabuli (master of the horse). ${ }^{82}$

In conclusion, constables - high and petty - likely originated not from statute but the common law. ${ }^{83}$ However, the matter is still obscure. They probably came on to the scene c. 1242. However, it may have been as late as 1285 or 1327.

\section{(d) Headboroughs, Borsholders etc.}

Earlier references to constables were to headboroughs (borsholders, tithingmen). ${ }^{84}$

- View of Frankpledge (Free Pledge). These earlier officers originated, in their turn, from the annual 'view [review] of frankpledge' ${ }^{85}$ which was Anglo-Saxon in origin. In those times, there emerged a mutual pledge among subjects to maintain public order (the 'king's peace'). This pledge was based on

\footnotetext{
${ }^{76} 3 \mathrm{Edw} 1$ (1275)(rep 1863). See also Coke, n 17, vol 2, pp 170-1. Other references to 'conestables' may be found by wordsearch in the Statutes of the Realm on CD (TannerRitchie Publishing, vol 1, 1101-1377, searchable text edition). The Statute of Northampton 2 Edw 3 c 3 (1328, rep 1967) referred to constables.

77 W Stubbs, Select Charters and other illustrations of English Constitutional History (Oxford, 1913, 9 th $^{\text {ed), p }} 362$ ('unus constabularius').

${ }^{78}$ Lee, $\mathrm{n} 68$, p 55 'This writ provides for the employment of these officers in parish and township, but it is more than likely that the office was not then a new one, because the word 'constable' is there used without any explanation being added, and it may therefore be assumed that its meaning was a matter of common knowledge.' Cf. P \& M, n 43, vol 2, p 582 '[In the period prior to Edward I (1272-1307) ] there was no professional police force. The only persons who are specially bound to arrest malefactors are the sheriff, his bailiffs and servants and the bailiffs of those who have the higher regalities. The constables who are becoming apparent at the end of our period are primarily military officers, though it is their duty to head the hue and cry.' They also refer to a writ of 1252 (more likely one of 1242).

${ }^{79}$ Blackstone, n 20, vol 1, p 344 'The petty constables are inferior officers in every town and parish, subordinate to the high constable of the hundred, first instituted about the reign of Edward III [1327-77]... Their ancient office is that of headborough, tithing-man, or borsholder...and who are as antient as the time of king Alfred...their more modern office is that of constable merely; which was appointed...so lately as the reign of Edward III, in order to assist the high constable.' Dalton, n 16, pp 39-40: 'Petty constables (in towns and parishes) were after devised (for the aid of the constables of the hundred)...' Both Blackstone and Dalton quoted Lambard, $\mathrm{n} 71$ (1599 ed), p 9 who asserted this. Cf. Coke seems to have thought they originated from the common law, vol 4, p 267 'Nota 10 E 4 fo 17 [1470] the petit constable was an officer by the common law per curiam. Vid 4 E 3 cap 3 [1330, rep] 25 E 3 ca 2 [1350, rep]'. See generally Ritson, n 71.

${ }^{80}$ R Stewart-Brown, Serjeants of the Peace in Medieval England and Wales (1936) suggests hereditary sarjeanties may have played the role of constables, pre-Edward I (1272-1307).

${ }^{81}$ Lambard, n 71 (1599 ed), pp 4-5 'The name constable is made (as I have read) of two English words put together, namely cuning (or cyng) and staple, which do signify the stay (or hold) of the king.' (see also 1640 ed, p 5). Lee, n 68, p 55 'The word 'constable' was imported by the Normans, but its etymology is not quite certain; formerly it was said to be derived from 'conning' a king, and 'stapel', a stay or prop, and to signify 'the king's right-hand man', but this is an unlikely solution, because the invaders despised the Anglo-Saxon language, and would not use a word which was partly derived from that tongue.'

${ }^{82}$ Lee, n 68, p 55 'Comes stabuli' meaning an equerry or master of the horse, has been generally accepted as correct. In England the title has been applied to a variety of functionaries, some high and some low, who had little in common beyond the fact that they all owed their authority to the Crown.' See also Ritson, n 71, p xv and Blackstone, n 20, p 343.

${ }^{83} R v$ Wyatt (1704) 1 Ld Raym 1189 (92 ER 286), 1 Salk 280 (91 ER 331) (high and petty constables were officers at common law before the Statute of Westminster 1285 and are the proper officers of JP's). Constable of Homeby's Case (1669) 1 Mod 13 (86 ER 693), per Twisden J 'High constables were not ab origine, but came in with justices of the peace, in the year of Henry IV [1399-1413].' Fitzherbert, n 14 (1538 ed), fo 48 (Of the Office of Constables) 'the office of the constable was an office at common law' (wording modernised). See generally, Ritson, $\mathrm{n} 71$, pp xvii-xxv.

${ }^{84}$ Halsbury, Statutes of England (5 ${ }^{\text {th }}$ ed with updates), vol 33(2), in a preliminary note to the Justices of the Peace Act 1361, notes that the earliest form of police organization seemed to have been a local association of persons who - as the king's subjects - became sureties for one another's keeping the peace. These associations elected principal men called headboroughs, borsholders or tithingmen who were responsible for maintaining order in the association. Hale (writing in the 1630's), n 19, vol 2, p 96 noted the authority of the tithingmen, headboroughs and borsholders were much the same as that of the constable. See also Lambard, $n 71$ (1599 ed), pp 6-9.

${ }^{85}$ Lee, n 68, p 4 'frankpledge signifying the guarantee for peace maintenance demanded by the king from all free Englishmen, the essential properties of this responsibility being, that it should be local, and that it should be mutual.' Walker, $\mathrm{n} 67$ (headborough). 'The chief of the 10 men who comprised a frankpledge (qv), elected by the court leet with the responsibility for the keeping of order in the area for which he was elected. They were gradually replaced by petty and parish constables.' See also Halsbury (4th ed), n 22, vol 36(1), para 101 and Coke, n 17, vol 2, pp 71-3. CK Allen, The Queen's Peace (Stevens, 1953), ch 4. Ibid, p 74 'the old Anglo-Saxon tithing seems to have been essentially a police-force, or posse, for the capture of thieves and felons.'
} 
the concept of allegiance to the sovereign - the frank pledge (free pledge) being the oath itself, which was given by the subject to a representative of the sovereign, to observe the king's peace. This system would seem to have been a very effective one in an England which - in Anglo-Saxon times - probably had a population of less than a million people (most of whom would have lived in small villages and towns) and where the system of law and order was otherwise scant;

- Who gave Frankpledge. This oath was given annually by able-bodied males over the age of $12^{86}$ who were not otherwise exempt ${ }^{87}$ (the reference to 'free' may have been that it was only given by 'free men' and not villains or slaves). It comprised an oath to observe obedience to the law both for them as well as their neighbours, the latter being a form of suertyship. ${ }^{88}$ The oath was renewed annually at the view of frankpledge conducted by the sheriff at his tourn. ${ }^{89}$ The 'view of frankpledge' later became synonymous with the court leet; ${ }^{90}$

- $\quad$ Tythings \& Hundreds. As part of this system of frankpledge, freemen without a freehold were grouped together in a 'tything' - a unit of ten households. Tythings were called boroes in some parts of England, the word signifying a pledge or surety. ${ }^{91}$ The leader of each tything was called the 'headborough'. Ten tythings made a 'hundred' (or wapentake) which became an administrative (and judicial unit) and part of the overall division of the kingdom into shires (counties), presided over by a sheriff (shire reeve) who was responsible to an earl, himself responsible to the sovereign;

- Police Role. Tythingmen and hundredmen were required to pursue and arrest - by way of ' $h u e$ and cry' ${ }^{92}$ all those who broke the peace. ${ }^{93}$ It is likely their leaders (headboroughs) adopted a more regular police role in this respect, being responsible for ensuring the king's peace in each tything or hundred by detaining malefactors.

As to the confusing nomenclature: ${ }^{94}$

\footnotetext{
${ }^{86}$ Bracton, $\mathrm{n} 10$, vol 2, p 351 said 12. So did Coke, n 17, vol 2, p 72 'every freeman at the age of 12 years'.Also, Lambard, n 71, p 8 (1640 ed). Cf. Mirror (writing c. 1290), n 11, p 9 'And turns of sheriffs and views of frankpledge were ordained, and that none of the age of fourteen years or upwards should be received in the kingdom beyond forty days, except men travelling in the guise of pilgrims or messengers, unless they were first pledged by freemen and sworn to the king by oath of fealty and afterwards received into a tithing.' See also Britton, n 9, pp 41,149-52 (see also note to the same). However, Coke thought 14 was a mistake, see n 17, vol 2, pp 121,147. See also AJ Robertson, The Laws of the Kings of England from Edmund to Henry I (Cambridge UP, 1925), p 185 re laws of Canute (1016-35), p 185 (which refers to age 12).

${ }^{87}$ Britton, n 9, p 149 'of twelve years old or upwards, except clerks, and knights and their children, and women, who are not in tithings, and of their mainpast [ie. not members of their household, servants and retainers] they are; of vagrants through the country who are not of any one's mainpast, and are of suspicious character.' Also, p 41 (persons in religion, clerks, knights and their eldest sons, women). In Anglo-Saxon times, villians were probably also exempt, but, it seems, not after the Norman Conquest. Britton cites the Laws of William I (1066-87) 'all the villains shall be in frankpledge.' Cf. Robertson, n 86, p 241 (the Ten Articles of William I) 'Everyone who desires to keep the status of a freeman shall be in a frankpledge.' Also, p 267.

${ }^{88}$ See J Maxwell, chapter on The English Police System in PH Winfield, Penal Reform in England (Macmillan, 1946), p 61 'With the development of monarchial government under Saxon rule there evolved the accepted responsibility for the maintenance of public order, or as it was termed, the king's peace. Under this general responsibility every freeman in the kingdom, in accordance with common law, became a pledged constable or conservator of the king's peace holding office not by payment, but by the right and responsibility of citizenship. This system is generally referred to as the frankpledge system - frankpledge signifying the guarantee for peace maintenance demanded from the king by all his subjects. The two essentials of this individual responsibility were that it was local and that it should be mutual.'

${ }^{89}$ Bellamy, n 69, p 90 'Twice a year the sheriff made his tourn of the hundred courts to receive presentments of offences both against the king's peace and against private citizens. At one of these sessions he made view of frankpledge. This was the old grouping together of most men into bands of about ten for purposes of public order. These were called tithings. The sheriff had to see that all able-bodied adult males, except nobles, clergy, and some categories of freemen, were in such a group. If a member of a tithing committed an offence the other nine were supposed to ensure his appearance in court when required, even by arresting him if they believed it was necessary. A fine was the penalty for failure. It was a system of anticipatory bail...'

${ }^{90}$ Burn, $\mathrm{n} 14$, vol 1 (1820 ed), p 571 'every of these pledges of [were] yearly presented and brought forth by their chief pledge at a general assembly for that purpose, which we yet in remembrance thereof do call the view of frankpledge, or the court leet.' See also Coke, n 17, vol 2, pp 68-73.

${ }_{91}$ Ibid, 'the companies [of ten men] are yet in some places of England called boroes, of the said word borge, borrow, or borhoe, signifying a pledge or surety; and in other places they are called tythings, because they contain ...ten men with their families.' See also P \& M, n 43, vol 1, pp 568-71.

92 The 'hue and cry' was regarded as fresh suit. Thus, an innocent man arrested by the same had no remedy against his pursuers. To obtain satisfaction, the victim had to discover the author of the false report. See Lee, n 68, p 35 and Coke, n 17, vol 3, pp 116-7. Also, Walker, n 67 (hue and cry). Allen, n 85, p 84 considered that the hue and cry in Anglo-Saxon times was aimed, above all, at cattle theft.

${ }^{93}$ Lee, $n$ 68, pp 4-5.

${ }^{94}$ Burn, n 14, vol 1 (1820 ed), p 570 'The word constable is evidently a compound; but it seems to be uncertain for whence it has been originally derived.' See also ns 81 and 82 .
} 
Headborough, borsholder, and chief-frankpledge are three words which describe the same functionary. The latter of Norman, and the two former of Saxon origin. Borsholder = borhes-ealder - borhes (often written borough as in 'headborough'), meaning pledge or surety. ${ }^{95}$

Thus, constables - and their pre-cursors - were legally charged with 'keeping the peace.' 96 To escape from the detention of such a person (or a sheriff or his underlings) whether using force (ie. prison breach) or without force (ie. escape) or with the forcible assistance of others (ie. rescue), was an offence. As a result, the converse must have developed. That is, it became an offence for a sheriff (or constable) to illegally detain a person - whether by arresting him or imprisoning him.

\section{In conclusion, the precursor to the constable was the headborough (borsholder). ${ }^{97}$}

\section{(e) Stocks \& Pillory}

From an early time, a person could be punished by being placed in the stocks or pillory. The stocks usually held a person sitting down by the legs, the pillory standing up by the arms and head. ${ }^{98}$ As to these:

- When the stocks first came into use it is unclear. ${ }^{99}$ However, an Act of 1351 decreed that stocks were to be built in every town. ${ }^{100}$ The pillory was Anglo-Saxon; ${ }^{101}$

- 'False imprisonment' included where a person was illegally placed in the stocks ${ }^{102}$ or the pillory. Also, any 'cage'. 103

John Rastell, Les Termes de la Ley, the $1^{\text {st }}$ edition which was in 1528 , defined imprisonment to include the stocks, as follows:

Imprisonment is the restraint of a man's liberty, whether it be in the open field, or in the stocks or cage

${ }^{95}$ Ibid, p 4, n 1. See also Burn, n 14, vol 1 (Constable), p 571 'head or elder of the boroes and chief of the pledges are all one; and in some shires where every third borough hath a constable, there the officers of the other are called thirdborowes.'

${ }^{96}$ Lambard (writing 1581), n 13, pp 141-2 'But as the keeping of the peace is more [e]specially recommended to the charge of justices of the peace, constables, petit-constables, borsholders, tithing men, and such like officers: so be they also armed with a larger measure of authority.' Burn, n 14, vol 1 (Constable), p 577 'Every high and petty constable are by the common law conservators of the peace' (quoting Hawkins, n 18, vol 2, c 8 s 6). Jacob, n $71\left(2^{\text {nd }}\right.$ ed, 1720), p 2 'High constables are appointed over hundreds, and petty constables are for towns and parishes within the hundred, as assistants to the high constables; and headboroughs, tithingmen, etc are for particular boroughs, hamlets, tithings and villages. The petty constables and tithingmen are not subordinate to the high constable in any thing that proceeds from his own authority merely, tho' this power is of a larger extent than theirs; and in places where there are no constables, but tithingmen, etc there the authority of such parish-officer equals that of the constable, within his limits; for he is in effect the constable of the peace.'

${ }^{97}$ By 1599 , they were being treated as one and the same, n 174. Arrest would also have been made by ordinary citizens, pursuant to their obligation to assist in the 'hue and cry'. Pulton (writing in 1609), n 15, p 12 'If a hue and cry be levied and pursued that a horse of such a colour or mark, so many beasts of such a sort, or age, or so many sheep of such a brand be stolen, and one is taken leading or driving of the said horses, beasts, or sheep: it is lawful for any man to apprehend and stay him, and to commit him to the constables of the town where he is apprehended, and by them to be put into the stocks, or safe kept, until he be delivered by due course of law, though he be not of evil fame, or name, but a man of good credit: for seeing the law by the hue and cry has accused him, by a course of law, he must be again acquitted and discharged: And in this case he that is so taken though he be after acquit of the felony, shall not have an action of trespass, false imprisonment, or other remedy against him, that did apprehend him.' Pulton cited 5 Hen $7 \mathrm{pl} 10$ fo 4a-5a (1489), Seipp Index, no 1489.41 (trespass for housebreaking, imprisonment etc). Translations of many of the 22,000 cases in the Yearbooks have been published online by professor David Seipp in the form of an Index, www.bu.edu/law/faculty/scholarship/yearbooks).

${ }^{98}$ See OED, n 36 (definition of stocks and pillory). For crimes for which a person was placed in the pillory see JM Beattie, Crime and the Courts in England 1660-1800 (Princeton University Press, 1986), pp 464-8.

${ }^{99}$ Lee, $\mathrm{n} 68$, pp 77-8 noted 'In the absence of proper lock-ups the village stocks were commonly used by the parish constable to secure his man until he could conveniently bring him before a magistrate but, as time went on, confinement in the stocks became the normal mode of punishment for minor offences.' A constable could put a person committing a BOTP in the stocks, see Fulwood v Gascoigne et al (1588)(123 ER 1034).

10025 Edw III stat $2 \mathrm{c}$ ii (1351). The stocks fell into disuse in the early $19^{\text {th }}$ century. See Walker, $\mathrm{n} 67$ (stocks) and EF Du Cane, The Punishment and Prevention of Crime (Macmillan \& Co, 1885), p 14 (last use of the stocks was after 1860). The pillory was abolished in 1837. Ibid.

${ }^{101}$ See the Statute of the Pillory and Tumbrel c. 1266 (Judicium Pillorie)(rep 1710). See also Lee, n 68, p 79. Coke, n 17, vol 3, p 219 `Pillory is a French word, and it is derived of the French word pilastre a pillar, columna...this punishment is very ancient, for the Saxons called it heals fang...'. A leet could be forfeited for not having a pillory. Ibid.

${ }^{102}$ For a case relating to the stocks, Pulton (writing in 1609), n 15, p 12 'In an action of trespass of assault, battery and imprisonment, the defendant pleaded that the plaintiff menaced to kill him, therefore he requested the constables to arrest the plaintiff to find sureties of his good behaviour, and the constables, and the defendant with them, did come and arrest him, and put him into stocks until he did find sureties: and this was allowed to be a good justification.' Pulton referred to 3 Hen 4 pl 3 fo 8b-9a (1402), see Seipp Index, n 97, 1402.003 (trespass for assault, battery, wounding and imprisonment). See also Scarret v Tanner (1592) Owen 105 (74 ER 933), Kingsmill (counsel) 'If a man that is threatened complain to the constable, he may compel the party to find surety for his good behaviour, and may justify the imprisoning him, or putting him in the stocks', referring to 22 Edw 4 p 16 fo 35b (1482), Seipp Index, n 97, 1482.133.

${ }^{103}$ See text to $n 104$. 
in the streets, or in a man's open house, as well as in the common gaol. And in all these places the party so restrained is said to be a prisoner, so long as he has not his liberty freely to go at all times to all places whether he will, without bail or mainprize. ${ }^{104}$

In conclusion, 'imprisonment' in legal terms, included detention in the stocks, pillory and cage.

\section{(f) Conclusion - What Comprised False Imprisonment: 1290-1600}

The position on what comprised 'false imprisonment' up the $17^{\text {th }}$ century seems best summarised by Coke, in volume 2 of his Institutes of the Laws of England, published in 1641. ${ }^{105}$ Coke noted that 'imprisonment' covered not just being detained in a prison. It also covered being detained in the custody of the king's officer. Thus, while noting that, at common law, to break out of the king's prison was a felony regardless of the crime for which the person was committed, Coke observed:

And so it is of a felon that is under custody of the king's officer (which is an imprisonment in law) and divers men do rescue or take him by force out of the custody of the king's officer, this is a felony in them all by the common law. ${ }^{106}$

The reference to 'police officer' would have included any sheriff (and his underlings), constable, headborough etc. Coke also stated:

Nota, he that is in the stocks, or under lawful arrest, is said to be in prison, although he be not infra parietes carceris [within the walls of a prison] ${ }^{107}$ and therefore this branch extendeth as well to a prison in law, as to a prison in deed. ${ }^{108}$

In short, from an early time, false imprisonment was a crime covering illegal detention in a prison, ${ }^{109}$ the stocks or the pillory. Also, by a constable or other legal officer. Further, detention could be in a building or not.

\section{(g) False Imprisonment: 1290 - 1600: Civil Remedy Came to Prevail}

Although the crime of false imprisonment existed at least by 1240, certain things are unclear:

- It is unclear in the period from 1240 - 1600 how many people were actually imprisoned ${ }^{110}$ or fined for this offence. One suspects that, as royal prisons took over from franchise prisons and royal justice improved, the number diminished;

- It is also unclear how many victims sought criminal - as opposed to - civil redress. ${ }^{111}$ One would imagine that a victim, once released, often found it easier (and more beneficial to assuage his anger) to obtain damages rather than retaliation. Further, one would suspect that the courts would, generally, have been reluctant to imprison errant sheriffs and police constables - not only to prevent antagonising

\footnotetext{
${ }^{104}$ The citation is from J Rastell, Les Termes de la Ley (printed by S Rycroft \& J Rawlins, 1708 ed). See also 22 Edw 3 Lib Ass pl 85 fo 104b-105a (1348), Seipp Index, n 97, 1348.293ass (Thorpe CJ noted that it was said to be imprisonment where one was arrested by force and against his will, although it was in the high street or elsewhere even if he was not imprisoned in a house).

${ }^{105}$ His commentary was in relation to the Statutum de Frangentibus Prisonam 1295 (repealed 1948), see McBain, n 1.

${ }^{106}$ Coke, n 17, vol 2, p 588. Also, vol 2, p 482 'every restraint of the liberty of a freeman is an imprisonment, although he be not within the walls of any common prison'. This wording was followed by many subsequent legal writers.

${ }^{107}$ Ibid. See also S Sheppard, The Selected Writings of Sir Edward Coke (Liberty Fund, 2003), vol 3, p 1234 (speech in Parliament on 25 March, 1628) 'No restraint ever so little, but it is an imprisonment.'

108 Ibid.

${ }^{109}$ Britton (c 1290), n 9, ch 12 (Of Prisoners), pp 36-7 'We will that a prison be accounted a place limited by us within certain bounds for the keeping of the bodies of men, which bounds we forbid on pain of death any one to pass with a felonious intent of escaping...'

${ }^{110}$ Since the punishment for false imprisonment was intended by the law to be retaliatory (see $\mathrm{n}$ 63), if the victim who had been illegally detained, had been 'loaded with irons', then the errant jailer was required to suffer the same. For the general power of citizens to arrest in the case of suspected felony, constables' powers of arrest, an increasing reluctance of the court to uphold local customs on the power of arrest and remedies prior to habeas corpus (where the offender was himself imprisoned for falsely imprisoning others), see J Baker, The Oxford History of the Laws of England, vol VI, 1483-1558 (Oxford UP, 2003), pp 88-91 (and habeas corpus, pp 91-4). For cases of false imprisonment with retaliation see AH Thomas, Calendar of Plea and Memoranda Rolls 1323-1364 (Cambridge UP, 1926),p 224 (plea before mayor and sheriffs of London on 11 March 1349. One JS imprisoned in Newgate for unpaid debt to R. Jury upheld an acquittance. R sentenced to imprisonment) and AH Thomas, Calendar of Early Mayor's Court Rolls 1298-1307, p 208 (plea in August 1305 for false imprisonment for debt in Newgate).

${ }^{111}$ A rather similar position prevails in the case of common innkeepers who refused travellers lodging when requested. Although, they could be prosecuted both criminally and civilly it is difficult to find any case of the former. See GS McBain, Abolishing the Strict Liability of Hotelkeepers [2006] JBL, Oct. 705-55. For early cases of false imprisonment in the civil context (trespass, with assault and battery also being pleaded), see ID Thornley (ed), Year Books of Richard II 11 Richard II 1387-1388 (Ames Foundation, 1937), pp 168,175,179, 247.
} 
powerful people in the case of the former but that, if done too often, no one would want to take on the job. ${ }^{112}$

Statham, whose Abridgment was published c. 1490, cited 5 cases of false imprisonment (faux emprisonement), making reference to Yearbook cases. ${ }^{113}$ It is noticeable that these cases concentrate on the civil remedy which was initiated by an action for trespass (more specifically, referred to as one for false imprisonment).

- Arrest by Sheriff. Reporting on a Yearbook case in $1411^{114}$ before the Common Pleas which comprised an action for trespass for the seizure of a horse for a debt, Statham noted 'If a man sues [brings] an action against another, and he shows to the sheriff that I was myself the person, whereas I was not, and the sheriff arrests me, I shall have a writ of false imprisonment against them both. By Hankford and Thirning; 115

- Form of Writ. Reporting on a Yearbook case in 1364 where a man was arrested in Essex and imprisoned in a village in Shropshire until he paid a fine, on the issue whether separate writs of false imprisonment were required, Statham noted 'In false imprisonment, the plaintiff counted that he took him in a vill in one county, and carried him into another county, and there imprisoned him. And the writ was challenged because it was for different trespasses in different counties. Fyncheden [Sjt]: We cannot have any other writ, for we cannot have a writ of the taking by itself, nor of the imprisonment by itself; therefore the writ was adjudged good, etc.; ${ }^{116}$

- $\quad$ Summons. Reporting on a Yearbook case of 1440 before the Common Pleas in a writ for debt, Statham noted, 'If a summons issues against JS, and the Capias [ad Satisfaciendum] issues against AS, and the sheriff takes JS; when JS shows this matter to the court, the process will be amended, and he shall plead with the plaintiff, and yet he shall have a writ of false imprisonment against the sheriff. And where the sheriff takes him by virtue of a Capias, and does not return the writ etc., which case is opposed to the other case, etc.; ${ }^{117}$

- Joinder in a Writ. Referring to an unidentified case in 1276, Statham noted 'Two cannot join in a [writ of] false imprisonment'; ${ }^{118}$

- Escheator. Referring to an unidentified case in 1457, Statham reported 'If the escheator takes the goods of a man who is outlawed, and does not mention them in his account, the other - when he is restored to a legal position - shall have a writ of false imprisonment against him, for if he has not accounted for them, he cannot justify, etc. By the opinion of the court in Trespass Coram Rege, etc., to wit: that he imprisoned him until he made a fine, etc.' The case was not identified by Klingelsmith. ${ }^{119}$

References to false imprisonment (faux emprisonment) may also be found in the Abridgments of Fitzherbert (in 1577) ${ }^{120}$ and of Brooke (in 1586). ${ }^{121}$ Many of these also relate to the civil remedy as opposed to the criminal

\footnotetext{
112 The position was the same as in the case of escape etc. A jailer who voluntarily (or negligently) let a prisoner escape in the case of felony or treason, legally, shared the same fate and, in the case of a misdemeanour, he was fined. However, I suspect that it was unlikely that jailers were so punished - not least since no one would then want to look after prisoners accused of these crimes, especially treason. See McBain, $\mathrm{n}$ 1, especially cases in which Holt CJ was judge in which he seems to have gone out of his way to protect Newgate jailers from whom prisoners committed for alleged treason had escaped, see McBain, n 1, n 178 and $R$ v Fell (1698) 2 Salk 272 (91 ER 237) and $R v$ Kendall and Row (1695) 1 Salk 346 (91 ER 304).

113 Statham, n 25, vol 2, pp 713-4. I cite from the Klingelsmith translation.

114 YB Mich 13 Hen IV, p 3, pl 5 (1411). See 13 Hen 4 pl 5, fo 2a-b and Seipp Index, n 97, 1411.054. Reference is also made by Klingelsmith to Fitzherbert, n 26, Faux Imprisonment, 11. See also Ibid, Trespas, 14, 55, 243.

115 William Hankford was CJ of the King's Bench 1413-23 (and a judge of the Common Pleas from 1398, which he was with reference to this case). William Thirning was CJ of the Common Pleas from 1396-1413. See J Sainty, The Judges of England 1272-1990 (Selden Society, 1993).

116 YB Mich 38 Ed III, p 29, pl 37 (1364). See 38 Edw 3 pl [37] fo 29(a) and Seipp Index, n 97, 1364.128. Reference is also made by Klingelsmith to Fitzherbert, n 26, Faux Imprisonment, 9.

${ }^{117}$ YB Trinity, 19 Hen VI, p 80, pl 10 (1440). See 19 Hen 6 pl 10 fo 80a-b and Seipp Index, n 97, 1441.053. Reference is also made by Klingelsmith to Fitzherbert, n 26, Faux Imprisonment, 12. Kingelsmith notes 'He ends a little more abruptly than does Statham, and does nothing to assist in clearing up the obscurity of the last phrase.' The writ of Capias ad Satisfaciendum was a writ of execution after judgment where a man had no lands or goods on which the unpaid debt might be levied. It was to take the body of the debtor and imprison him until satisfaction of the debt was made.

${ }^{118}$ Reference is made to a case in Paschal 4 Ed I [1276]. Klingelsmith notes 'We have no early printed Year Books for the reign of Ed I [1307-27]. It is not yet known how many years of that reign there may be in manuscript. Probably more than has usually been thought possible.'

119 She states 'The case has not been identified in Y.B. Trinity, 35 Hen. VI, or in the early abridgments.' Cf. 35 Hen 6 fo 99 , Seipp Index, n 97, $1457.041 \mathrm{abr}$.

${ }^{120}$ See n 26. Fitzherbert (faux emprisonment) refers to 13 cases which can be tracked via Seipp Index, n 97 (eg. Fitzherbert no 7 refers to 2 Hen 7 p 1 fo 15b-16a, Seipp Index n 97, no1487.024. Action for false imprisonment. Whether common fame sufficient to arrest).
} 
one. Law dictionaries also emphasised the former. Thus, John Cowell, in his Law Dictionary or Interpreter (1607), defined false imprisonment as follows:

False Imprisonment. Falsum imprisonamentum, is a trespass committed against a man by imprisoning him without lawful cause. It is also used for a writ which is brought upon this trespass, FNB fol 86,88. Vide Cooke [Coke], and the New Book of Entries, verbo false imprisonment. ${ }^{122}$

In conclusion, by 1600, the offence of false (illegal) imprisonment included: (a) illegally imprisoning a person in a prison, the stocks or the pillory; (b) a police official (whether constable, tythingman etc) illegally detaining a person. Detention could be anywhere - whether in a building or the open fields. Indeed, the offence had changed very little from when Bracton wrote about it, c. 1240.

\section{False Imprisonment: 1600 - 1800}

Pulton, writing in a useful text on the criminal law, De Pace Regis et Regni (1609), summarised the law on false imprisonment in a succinct fashion:

Imprisonment is where a man is arrested by force, and against his will, and is restrained of his liberty, and put in a common gaol, or other gaol, in a cage, or in the stocks, or otherwise kept in the high street, or open field, if he be in restraint, and cannot go at liberty when he will, but is bound to become obedient to the will of the law, and is in the custody of the law. And in all the cases aforesaid, the party so restrained, is said to be a prisoner, so long as he has not his liberty, freely to go at all times, when he will, without bail, mainprise, or other restraint:

And therefore if one person do arrest, imprison, or otherwise restrain another person of that liberty, without sufficient and lawful cause, the party grieved may have an action of false imprisonment, or an action of trespass against him that do so arrest, or imprison him, and recover damages against him. And the king shall also have a fine of him, for that his law is contemned, and his peace is broken, in that one of his subjects presumes to imprison another without sufficient warrant of him, or his law; seeing imprisonment of an other by only [probably should be 'any'] act, will, or commandment (without offence of the law) is one of the king's most royal prerogatives, and only annexed to the majesty, dignity, and imperial crown of his realm ...

But in many cases one person may arrest, imprison and restrain an other of his liberty and no action of false imprisonment, action of trespass, or other remedy will be had against him. ...As first it is a lawful imprisonment which is done by the absolute commandment of the king, the chief sovereign head of the common weal by his own mouth, or by the privy council, (which speak and direct by his authority) or by the absolute commandment of the king's justices ${ }^{123}$ (spelling modernised).

After citing various instances of lawful imprisonment and various cases relating to false imprisonment, ${ }^{124}$ Pulton states:

By which foresaid cases, and many more, it appears that imprisonment is lawful, and sufficiently authorised by the common laws and statutes of this realm in divers respects, and for many crimes, and there is by it no [BOTP], nor offence to the law, when it is inflicted by the warrant of the law: for it advances as much the justice and peace of the realm to have offenders punished, as to have the innocent protected. But the imprisonment which tends to the [BOTP], and the offence of the law is, when one person or more upon his or her own authority, either in revenge of some supposed wrong received, or in

\footnotetext{
121 See n 27. Brooke (faux imprisonment) refers to 43 cases which can be tracked via Seipp Index, n 97.

122 The reference is to A Fitzherbert, New Natura Brevium, first published in 1534 (last ed, 1793), to the wording of the relevant writ of trespass. I cite from the 1718 ed of the same (printed by E Nutt \& R Gosling, rep Univ of Michigan library), see 86K (p 192) 'And if a man do imprison another, then the form of the writ of trespass is...'. See also 88A (p 194 ('And there is another writ of a house broken into and prisoner taken away thus...'. Also, 88D ('And if a man taketh his villain and puts him into the stocks, and others come and break the stocks, and let him out, he shall have an action of trespass, and the form is...). Also 88P ('And another for taking him and imprisoning him in one place, and from thence carrying of him to prison in another place, and there detaining him in prison).' Also 98C ('And if a man take another man and imprison him, and compel him to make a statute merchant, or a release, or an acquittance, he shall have an action of trespass for the same, and the writ shall recite the matter, and the detaining in prison of him etc'). See also E Coke, Booke of Entries (1671)(False Imprisonment).

${ }^{123}$ Pulton, n 15, p 10-1. See also Dalton, n 16 (writing in 1619), p 306 'Imprisonment, is where a man is arrested against his will, and is restrained of his liberty, but putting him into the gaol, cage, or stocks, or into some house, or otherwise keeping him in the high street, or open field, so as he cannot freely go at liberty when and wither he would.' Also, 'An arrest is the apprehending, and first restraining of a man's person, depriving it of his own will and liberty; and may be called the beginning of imprisonment.'

124 Ibid, pp 12-4.
} 
hope of a private gain expected, or for some other cause, will of his or their own authority imprison or arrest an other; for the redress whereof the party grieved shall have an action of false imprisonment, or an action of trespass, and recover his damages. And the same offender which before did wrongfully imprison an other, shall then upon his conviction by verdict, or his own confession, be himself lawfully imprisoned, until he hath paid to the king a fine. ${ }^{125}$ (spelling modernised)

Other legal writers also considered the position, ${ }^{126}$ as did the Abridgments of: Hughes (in 1660-3), ${ }^{127}$ Rolle (in 1668), ${ }^{128}$ Sheppard (in 1675), ${ }^{129}$ Nelson (in 1725-6), ${ }^{130}$ Bacon (in 1736), ${ }^{131}$ and Viner (in 1741-57). ${ }^{132}$ However, little was really added to the statement of Pulton save that 'false imprisonment' became more closely allied with the civil remedy, as opposed to the criminal one - doubtless, because of the greater utilisation of the former as opposed to the latter. Thus, Giles Jacob, Catalogue of all the Writs and Processes, that issue out of the Several Courts at Westminster (only edition, 1717) stated:

False Imprisonment. Falsum Imprisonamentum is a writ brought upon a trespass committed against a man by imprisoning him without cause, or unlawfully detaining him. ${ }^{133}$

Blackstone (writing in 1768) summarised the position in his time:

To constitute the injury of false imprisonment there are two points requisite: 1 . The detention of the person; and, 2. The unlawfulness of such detention. Every confinement of the person is an imprisonment, whether it be in a common prison, or in a private house, or in the stocks, or even by forcibly detaining one in the public streets. ${ }^{134}$

Unlawful, or false, imprisonment consists in such confinement or detention without sufficient authority: which authority may arise either from some process from the courts of justice; or from some warrant from a legal officer having power to commit, under his hand and seal, and expressing the cause of such commitment; or from other special cause warranted, for the necessity of the thing, either by common law, or act of parliament; such as the arresting of a felon by a private person without warrant, the impressing of mariners for the public service, or for the apprehending of waggoners for misbehaviour in the public highways. ${ }^{135}$

False imprisonment also may arise by executing a lawful warrant or process at an unlawful time, as on a Sunday; ${ }^{136}$ or in a place privileged from arrests, as in the verge of the king's court. This is the injury.

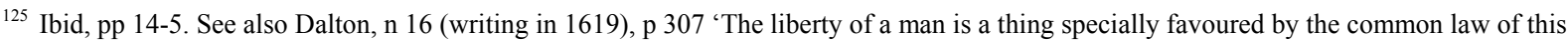
land: And therefore if any of the k[ing's] subjects shall imprison another without sufficient warrant of him, or his law, the party grieved may have his action and shall recover damages against the other; and the $\mathrm{k}[\mathrm{ing}]$ also shall have fine of him: For imprisonment of another, without offence of the law, is one of the k[ing's] royal prerogatives, and only annexed to the Crown'. (spelling modernized).

${ }^{126}$ That said, Hawkins (the $1^{\text {st }}$ ed was in 1716-21, see n 18) did not have much to say. The last edition of Hawkins was in 1824.

${ }^{127}$ See n 29, vol 2 (under the title 'False Imprisonment: and Imprisonment', referring to 27 cases). It may also be noted that, by the time of James I (1603-25) the 'tything' had died out. It was re-placed by the parish - with the parish constable, to some extent, taking the role of tythingman. Maxwell, n 88, p 66 'During the reign of James I the tything could no longer be said to exist, due to the growth of trade, the increase of population and the improved facilities of moving from one part of the country to another and gradually the parish took the place of the tything, whilst the parish constable gradually replaced the tythingman.' See also Lee, n 68, p 120.

${ }^{128}$ See $\mathrm{n} 28$.

${ }^{129}$ See $\mathrm{n}$ 30. See also J Herne, The Pleader (London, 1657) ('False Imprisonment'). He cites 5 precedents of false imprisonment (cases in $1607-8,1619 \& 1621$ ) in which assault and battery were also pleaded (this likely gave later legal writers the impression false imprisonment was a category (species) of assault and battery, when it is not, see 6).

${ }^{130}$ See $\mathrm{n} 31$.

${ }^{131}$ See $\mathrm{n} 32$.

${ }^{132}$ See $\mathrm{n} 33$.

${ }^{133}$ G Jacob, A Catalogue of all the Writs and Processes, that Issue out of the Several Courts at Westminster etc (E Nutt, 1717), p 59. See also, for example, R Kilburn, Choice Precedents upon all Acts of Parliament relating to the Office and Duty of a Justice of the Peace (1715), $\mathrm{p} 287$ (a warrant for false imprisonment) ‘These are in his majesty's name to command you... to bring before me or some other of his majesty's justices of the peace for the said county, the body of $[\mathrm{X}]$ to answer to all such matters and things as on his majesty's behalf shall be objected against them by [Y] for falsely and unlawfully imprisoning her by the space of six hours...'.(italics supplied). See also J Chitty, A Practical Treatise on the Criminal Law (1826), vol 3, 835 (indictments re false imprisonment) 'unlawfully, and injuriously, against the will and without the consent of $[\mathrm{Y}]$ and also against the laws of this realm, without any legal warrant, authority, or justifiable cause whatsoever, did imprison and detain...'. Also, p 839 'without any legal warrant or authority, and also without any reasonable or probable cause whatsoever, and contrary to the laws of this realm, unlawfully did imprison and detain in prison...'

${ }^{134}$ Blackstone cites Coke, n 17, vol 2, p 588, see the text to ns $106 \& 108$.

${ }^{135}$ He cites 7 Geo III c 42 (1766, Act on Highways, rep).

${ }^{136}$ He cites 29 Car II c 7 (1677, Act on Sunday Observance, rep).
} 
Let us next see the remedy: which is of two sorts; the one removing the injury, the other making satisfaction for it. ${ }^{137}$ (wording divided for ease of reference).

Blackstone then notes the means of removing the injury were by a writ of: (a) mainprize; ${ }^{138}$ (b) odio and atia; ${ }^{139}$ (c) de homine replegiando; ${ }^{140}$ and (d) habeas corpus. ${ }^{141}$ Noting that these writs were antiquated save for habeas corpus, Blackstone discussed the latter at length before concluding:

The satisfactory remedy for this injury of false imprisonment, is by an action of trespass, vi et armis, usually called an action of false imprisonment; which is generally, and almost unavoidably, accompanied with a charge of assault and battery also: and therein the party shall recover damages for the injury he has received; and also the defendant is, as for all other injuries committed with force, or $v i$ et armis, liable to pay a fine to the king for the violation of the public peace. ${ }^{142}$

In conclusion, false imprisonment, essentially, comprised the illegal detention of a person - whether in prison or otherwise - and by whomsoever. As Blackstone pointed out, the remedy for illegal detention was to secure a writ of habeas corpus (the other writs had become obsolete). As for punishment, a party could proceed civilly by an action for trespass (more particularly, an action of false imprisonment) in which damages were sought. Alternatively, the party committing the unlawful detention was liable 'to pay a fine to the king for the violation of the public peace'. Blackstone notes, elsewhere, that imprisonment was also part of the punishment. ${ }^{143}$

\section{False Imprisonment: $1800-1883$}

From the $19^{\text {th }}$ century, in legal texts, the concept of false imprisonment tended to be discussed very much in the context of the civil, as opposed to the criminal, offence. This is not especially surprising.

- With $19^{\text {th }}$ century reforms to the penal system and the professionalization of the police and jail system, the chances of persons being illegally arrested and imprisoned were much reduced. Further, such instances were rarely deliberate. Rather, they arose from mistake or negligence;

- Therefore, to imprison (or fine) errant JP's, gaolers and police constables was of little legal benefit. The civil remedy was to be preferred;

- Further, when the criminal offence of false imprisonment was discussed in legal texts, the offence now tended to be treated - not as a separate substantive offence - but as a 'species' (category) of assault.

As to various legal texts which evidence this:

\section{(a) East (1803) \& Buller (1788)}

East, in his Treatise on the Pleas of the Crown in $1803,{ }^{144}$ stated:

What has been said before respecting common assaults and batteries will suffice also to excuse the

\footnotetext{
${ }^{137}$ Blackstone, n 20, vol 3, pp 127-8.

${ }^{138}$ Ibid, p 128 'The writ of mainprize, mancaptio, is a writ directed to the sheriff, (either generally, when any man is imprisoned for a bailable offence, and bail hath been refused; or specially, when the offence or cause of the commitment is not properly bailable below) commanding him to take sureties for the prisoner's appearance, usually called mainpernors, and to set him at large. Mainpernors differ from bail, in that a man's bail may imprison or surrender him up before the stipulated day of appearance; mainpernors can do neither, but are barely sureties for his appearance at the day: bail are only sureties, that the party may be answerable for the special matter for which they stipulate; mainpernors are bound to produce him to answer all charges whatsoever.'

${ }^{139}$ See $\mathrm{n} 51$.

${ }^{140}$ Blackstone, n 20, vol 3, p 129 'The writ de homine replegiando, lies to replevy a man out of prison, or out of the custody of any private person, (in the same manner that chattels taken in distress may be replevied, of which in the next chapter) upon giving security to the sheriff that the man shall be forthcoming to answer any charge against him. And, if the person be conveyed out of the sheriff's jurisdiction, the sheriff may return that he is eloigned, elongates; and which a process issues (called a capias in withernam) to imprison the defendant himself, without bail or mainprize, till be produces the party. But this writ is guarded with so many exceptions, that it is not an effectual remedy in numerous instances, especially where the crown is concerned. The incapacity therefore of these three remedies to give complete relief in every case has almost entirely antiquated them, and has caused a general recourse to be had, in behalf of persons aggrieved by illegal imprisonment to... the writ of habeas corpus, the most celebrated writ in the English law.'

${ }^{141}$ Ibid, p 131 'the great and efficacious writ in all manner of illegal confinement, is that of habeas corpus ad subjiciendum; directed to the person detaining another, and commanding him to produce the body of the prisoner within the day and cause of his caption and detention, $a d$ faciendum, subjiciendum, et recipiendum, to do, submit to, and receive, whatsoever the judge or court awarding such writ shall consider in that behalf.' For these writs see also Coke, n 17, vol 4, pp 181-2.

${ }^{142}$ Blackstone, n 20, vol 3, p 138.

${ }^{143}$ Ibid, vol 4, p 218 'Inferior degrees... of false imprisonment are also punished by indictment (like assaults and batteries) and the delinquent may be fined and imprisoned.'

${ }^{144}$ EH East, $A$ Treatise of the Pleas of the Crown (London, 1803).
} 
brevity of this chapter. ${ }^{145}$ The subject of false imprisonment is amply discussed in books treating of the civil redress of the party injured, which are in common use. ${ }^{146}$ In one of these it is described to be every restraint of a man's liberty under the custody of another, either in a gaol, house, stocks, or in the street, whenever it is done without a proper authority. Whatever is a legal justification of the imprisonment, may be given in evidence under the general issue, upon an indictment; as in the case of an assault: and the punishment for this offence is as in the case of other misdemeanours. ${ }^{147}$

As to Buller whom East cited, in his Introduction to the Law relative to Trials at Nisi Prius (1788), Buller stated:

Every restraint of a man's liberty under the custody of another, either in a gaol, house, stocks, or in the street, is in law an imprisonment; and whenever it is done without a proper authority, is false imprisonment, for which the law gives an action; and this is commonly joined to an assault and battery; for every imprisonment includes a battery, and every battery is an assault. ${ }^{148}$

Cases Buller mentioned included Doyley $v$ Whiter (1608) ${ }^{149}$ where an action of false imprisonment was brought against a sheriff and Middleton v Price (1742) where a court bailiff was accused of false imprisonment.

${ }^{150}$ Reference was also made to the Constables Protection Act 1750 (still extant in part) which accorded some protection for constables acting pursuant to JP's warrants (as well as to persons acting under their orders). ${ }^{151}$

\section{(b) $\underline{\text { Russell (1819) \& Archbold (1822) }}$}

The legal writer, Russell, in the first edition of his Crimes and Misdemeanors in 1819 - a seminal work which was to last until 1964 - ${ }^{152}$ stated:

An unlawful imprisonment is also an assault; for it is a wrong done to the person of a man, for which, besides the private satisfaction given to the individual by action, the law also demands public vengeance, as it is a breach of the king's peace, a loss which the state sustains by the confinement of one of its members, and the infringement of the good order of society. ${ }^{153}$ To constitute the injury of false imprisonment, there must be an unlawful detention of the person. With respect to the detention, it may be laid down that every confinement of the person, whether it be in a common prison, or in a private house, or by a forcible detaining in the public streets, will be sufficient. ${ }^{154}$

And such detention will be unlawful unless there be some sufficient authority for it, arising either from some process from the courts of justice, or from a warrant of a legal officer, having power to commit under his hand and seal, and expressing the cause of such commitment; or arising from some other special cause sanctioned, for the necessity of the thing, either by common law or by act of parliament. ${ }^{155}$ And the detention will be unlawful, though the warrant or process, upon which it is made, be regular, in

\footnotetext{
145 That said, East did not discuss false imprisonment in the context of assault and battery, see pp 406-27.

${ }^{146}$ East referred to Buller, Nisi Prius 22 (see text and n 148) and to Bacon, n 32, vol 6, p 569 (see eg $5^{\text {th }}$ ed (1798), edited by M Gwillim, Trespass. For actions of false imprisonment, see pp 569-75).

${ }^{147}$ East, n 144, p 428. East also notes that 'The most aggravated species of false imprisonment is the stealing and carrying away, or the secreting of any person, sometimes called kidnapping, which is an offence at common law, punishable by fine, imprisonment, and pillory.'

${ }^{148}$ F Buller, An Introduction to the Law relative to Trials at Nisi Prius (London, 1788), p 22. His statement that every imprisonment includes a battery is incorrect.

${ }^{149}$ Cro Jac 323 (79 ER 276) (action for false imprisonment of plaintiff's wife). See also Herne, n 129, p 489.

${ }^{150}$ Str 1184 (93 ER 1115). See also 1 Raym 740 (91 ER 1395)(1700) (collector of taxes cannot justify an imprisonment for non payment of taxes).

${ }^{151} 24$ G 2 c 44 (rep) (no writ shall be sued against a JP for what he shall do in the execution of his office until notice in writing of the intended writ has been delivered to him or left at the usual place of his abode etc. No action shall be brought against a constable or other officer or any person acting under his order for any thing done in obedience to a JP's warrant until demand is made for a perusal and a copy of such warrant etc.). For discussion of the Constables Protection Act 1750, see GS McBain, Our Criminal Law should only be 200 Years out of Date - and it should be Consolidated (2014) Rev of European Studies, vol 6, no 2, pp 1-35.

152 The last edition was edited by JWC Turner.

${ }^{153}$ Reference was made to Hawkins, n 18, vol 1, c 60 s 7 (1739 ed). In the $1^{\text {st }}$ edition of his work (in 1716-21) Hawkins stated: 'It seems also the better opinion, that he who is threatened to be imprisoned by another, has a right to demand the surety of the peace, for every unlawful imprisonment is an assault and wrong to the person of a man. And the objection, that one wrongfully imprisoned may recover damages in an action etc and therefore needs not the surety of the peace, is as strong in the case of battery as imprisonment, and yet there is doubt, but that one threatened to be beaten may demand the surety of the peace.'(repeated in $3^{\text {rd }}$ ed in 1739). Reference was also made by Russell to Blackstone, $n$ 20, vol 4, p 218 (see text to n 137).

${ }^{154}$ Reference was made to Coke, n 17, vol 2, p 589 (see text to ns 106 \& 108) and to Blackstone, n 20, vol 3, p 127 (see text to n 137). Also to Comyn, n 34, vol 4, 'Imprisonment.'

${ }^{155}$ Reference was made to Blackstone, n 20, vol 3, p 127(see text to n 137).
} 
case they are executed at an unlawful time, as on a Sunday; or in a place privileged from arrests, as in the verge of the king's court. ${ }^{156}$...It has been supposed that every imprisonment includes a battery ${ }^{157}$...but this doctrine was denied in a recent case, where it was said by the court that it was absurd to contend that every imprisonment included a battery. ${ }^{158}$ (wording divided for ease of reference).

Archbold considered only the criminal offence of false imprisonment and allied it with assault and battery. Thus, in the $1^{\text {st }}$ edition of his work in 1822, Archbold stated that false imprisonment was a misdemeanour at common law, punishable with a fine or imprisonment and:

All the prosecutor has to prove, is the imprisonment; it is for the defendant to shew that he was justified in what he did, and that the imprisonment was lawful. And every confinement of the person is an imprisonment, whether it be in a common prison, or in a private house, or in the stocks, or even by forcibly detaining one in the public streets. ${ }^{159} \ldots$

If the prosecutor fail in proving the imprisonment, he may proceed to prove the second count for the assault and battery. ${ }^{160}$

Archbold then provided a sample indictment of an assault and false imprisonment. ${ }^{161}$

In conclusion, in the early $19^{\text {th }}$ century, the tendency in legal texts was to view the offence of false imprisonment more in its civil, than its criminal, context. Also, to view the criminal offence as a species of assault.

\section{(c) Gabbett (1843) \& Paterson (1877)}

Gabbett, in his Treatise on the Criminal Law (1843), stated:

Unlawful imprisonment is another species of assault, for which, besides the private satisfaction given to the individual by action, an indictment may be maintained as a breach of the king's peace, affecting the public by the confinement of one of its members, and as an infringement of the good order of society. To constitute this injury, there must be unlawful detention of the person; which may be not only in a common prison, or in a private house, but also in the public streets... ${ }^{162}$

We shall have occasion in another part of this work to inquire what arrests are lawful; either by public officers, or private individuals; and shall here only lay it down in general, that every arrest or detention of the person is unlawful, which is not justified by the process of some court of justice, or the legal warrant of a magistrate; or which does not arise out of the necessity of the case, or is not sanctioned by common law, or act of parliament. ${ }^{163}$ (wording divided for ease of reference)

Paterson, in his Commentaries on the Liberty of the Subject and the Laws of England relating to the Security of the Person (1877), adopted a similar approach of allying false imprisonment with assault and battery. He stated:

\footnotetext{
${ }^{156}$ Reference was made to 29 Car II c 7 (1677, rep). Also, to Comyns, n 34, vol 4, 'Imprisonment.'

${ }^{157}$ Cf. Hawkins, see n 153 (re assault).

${ }^{158}$ WO Russell, A Treatise on Crimes and Misdemeanors ( $1^{\text {st }}$ ed, 1819), vol 1, pp 864-6. The wording in Russell had not changed by the 6th ed, issued in 1896. However, reference was also made to Bird v Jones (1845) 7 QB 742 (115 ER 668) where a person attempting to go in a particular direction was prevented from going in any direction but one, not being that in which he endeavoured to pass. Held, this was not an imprisonment - whether the person had, or had not, a right to pass in the first mentioned direction). This case contains useful observations on the concept of imprisonment.

159 Archbold cited Coke, n 17, vol 2, p 589 (see text to ns 106 \& 108) and the Case of Sir Miles Hobart and William Stroud (1630) Cro Car 210 (79 ER 784) (every place where a person is restricted of his liberty is a prison. However, if a person be committed to a particular place, and instead of confinement within the walls he goes at large, he may be indicted for a misdemeanor, although he had the jailer's permission). Also cited is Comyns, see $\mathrm{n} 156$.

$160 \mathrm{JF}$ Archbold, Pleading and Evidence in Criminal Cases (London, 1822), p 254.

${ }^{161}$ Ibid, p 253. After citing that JS assaulted JN and wounded him, it continues, p 253, that 'JS... against the laws of this realm, and without any legal warrant, authority, or reasonable or justifiable cause whatsoever, did imprison, and detain so imprisoned there for a long space of time, to wit, for the space of ten hours then next ensuing...to the great damage of the said JN, and against the peace of our lord the king, his crown and dignity.' For a similar indictment in 1749, W Stubbs \& G Talmarsh, The Crown Circuit Companion (H Lintot, 1749), p 129 and for one in 1819 , see J Chitty, A Practical Treatise on the Criminal Law (Philadelphia, 1819), vol 4, p 835 (assaults and false imprisonment).

${ }^{162}$ Gabbett quotes Thorpe CJ, see n 104. See also D Keane \& CT Smith, Selwyn's Abridgment of the Law of Nisi Prius (Stevens \& Sons, 1869), ch 24. Inter alia, it notes: 'False imprisonment is a restraint on the liberty of the person without lawful cause; either by confinement in prison, stocks, house, etc, or even by forcibly detaining the party in the streets against his will. For this injury an action of trespass lies, usually termed an action for false imprisonment.'

${ }^{163}$ At pp 82-3. He quotes Blackstone, n 20, vol 3, p 127 (see text to n 137).
} 
Every restraint of a man's liberty or keeping the custody of another, either in a gaol, or in a house, or in the stocks, or even in the street, is in law an imprisonment, for which the law gives an action. And it is commonly joined to assault and battery, for every imprisonment includes a battery, and every battery an assault. One of the remedies for this false imprisonment is an action of damages, and this remedy it is now necessary to explain. ${ }^{164}$

Paterson also stated:

The four remedies described by Coke in case of unlawful imprisonment are (1) an action on the statute or great charter [ie. Magna Carta]; (2) an indictment; (3) a habeas corpus; (4) an action for false imprisonment. ${ }^{165}$ But practically there are only two remedies, namely, by action, or by habeas corpus.

If the imprisonment has been temporary, arising from mistake or on some ground discovered to be untenable, and the imprisonment is past, then the appropriate remedy is by action. If the imprisonment is continued and persisted in, then the appropriate remedy is by writ of habeas corpus. The former generally releases all kinds of mistakes, however trivial, after the imprisonment has ceased. The latter goes to the root of the matter and copes with every conceivable difficulty involved in a continuing imprisonment, which is illegal, but which is sought to be stopped at once.' ${ }^{166}$ (wording divided for ease of reference)

Paterson then discussed the civil remedy in detail, but not the criminal one. ${ }^{167}$

\section{(d) Harris (1881) \& Stephen (1883)}

Harris, in his Principles of the Criminal Law (1881), linked false imprisonment with assault. Thus, he stated:

False imprisonment is a misdemeanor at common law, punishable by fine or imprisonment, or both. All that the prosecutor has to prove is the imprisonment; it is for the defendant to justify what he did. A count for common assault is usually added. Every confinement or restraint of the liberty of a person is an imprisonment; for example, by detaining a man in the streets. Though a party, on being shewn a magistrate's warrant, goes willingly at the desire of a constable, this is an imprisonment which the constable may be called upon to justify.' 168

Finally, Sir James Fitzjames Stephen, the great criminal jurist, published his History of the Criminal Law of England in 1883. It did not deal with false imprisonment as such. ${ }^{169}$ Nor did Stephen's other works. ${ }^{170}$ However, it seems clear that Stephen also regarded false imprisonment as a species of assault since, in his Digest of the Criminal Law: Crimes and Punishments (1883), art 241 (assault and battery and assault defined) he declared:

An assault is...(c) the act of depriving another of his liberty, in either case without the consent of the person assaulted, or with such consent if it is obtained by fraud. ${ }^{171}$

In conclusion, by the $19^{\text {th }}$ century, the criminal offence of false imprisonment was treated as a species of assault. Further, reference to the civil offence pre-dominated. It may also be noted that the crime itself had also become very much simplified, in that it was - as a result of changes - in effect, limited to illegal detention in: (a) her

\footnotetext{
164 J Paterson, Commentaries on the Liberty of the Subject and the Laws of England relating to the Security of the Person (Macmillan \& Co, 1877), vol 2, p 191.

${ }^{165}$ He cited Coke, n 17, vol 2, p 55 (commentary on Magna Carta, c 29 which provided, inter alia, that 'no freeman shall be taken or imprisoned... but by lawful judgment of his peers.'). See also JH Baker, An Introduction to English Legal History (4 ${ }^{\text {th }}$ ed, 2002, pp 472-4). Dalton, n 16, p 307 'And by this statute of Magna Carta, every arrest or imprisonment, and every oppression against the law of the land, is forbidden; and if any judge, officer, or other person, against the law, shall usurp any jurisdiction, and by colour thereof, shall arrest, imprison, or oppress any man, it is punishable by this statute.' See also Comyns, n 34, vol 4, p 379 (1792 ed) 'If a man be imprisoned without cause, there may be an indictment against him, who did the wrong, upon the statute [Magna Carta].'

166 Paterson, n 164, vol 2, p 193.

${ }^{167}$ It may be noted that Paterson, as to rationale for false imprisonment, stated, n 164, p 194: 'The action for false imprisonment is founded on the doctrine, that a man's liberty is too precious a thing to be interfered with even for a few moments, and whether the person, who so interfered, made a mistake and acted inadvertently or deliberately, is of no consequence. He who interferes with another's liberty must take the risk of his own mistakes; and hence it is immaterial, what was the wrongdoer's motive, or how he came to do the wrongful act. It is enough to be aggrieved that he suffered the wrong; and whoever caused that wrong, whether master, or servant, or agent, must be responsible in damages. Most of such actions arise out of persons, or their servants, erroneously giving others into custody of a constable, and the length of the imprisonment is altogether immaterial, except as rendering the damages, which are recoverable, greater or less in amount.'

${ }^{168}$ SF Harris, Principles of the Criminal Law (Stevens \& Haynes, $2^{\text {nd }}$ ed, 1881), p 188.

${ }^{169}$ It may be noted Stephen also did not deal with assault or battery in any detail in his work.

${ }^{170}$ See eg. JF Stephen, A General View of the Criminal Law of England (1863).

${ }^{171}$ FJ Stephen, A Digest of the Criminal Law: Crimes and Punishments (Macmillan \& Co, 1883), p 177.
} 
Majesty's prisons; or (b) by police constables, for the following reasons:

- $\quad$ Prisons. By 1883, all prisons were Crown prisons - franchises of prisons having lapsed or been terminated. Also, the process of imprisonment had been professionalised, as had the jailers. Thus, the prospect of a person being falsely imprisoned was much reduced, since a prison would only receive persons pursuant to the appropriate judicial orders; ${ }^{172}$

- $\quad$ Police Constables. With the professionalization of the London police force from $1829^{173}$ and that in the counties from 1839, there were no longer any headboroughs (borsholders) or high constables. ${ }^{174}$ There were only police constables. ${ }^{175}$ Further, local police forces were soon to be a thing of the past. So too, private police forces. ${ }^{176}$ Also, high sheriffs had become a ceremonial office. ${ }^{177}$ Finally, police constables had a fairly extensive protection when acting pursuant to a JP's warrant, ${ }^{178}$ as did JP's themselves;

- Private Persons. The 'hue and cry' was obsolete by the $19^{\text {th }}$ century, ${ }^{179}$ and the presence of a professional police force generally precluded the need for constables to request the assistance of private persons in detaining people. Thus, actions against private persons for false imprisonment were more rare;

- $\quad$ Pillory and Stocks. The pillory was abolished in 1816 for all offences apart from perjury. In 1837 , it ended for good. $^{180}$ The stocks was obsolete by 1880 ;

- Civil Remedy. The civil remedy for false imprisonment (damages) was more often utilised than the criminal one (the remedial writ being habeas corpus). Thus, one does not come across cases of jailers and constables being imprisoned for false imprisonment, although they may have been fined;

False imprisonment, incorrectly, also tended to be treated as a 'species' (category) of assault. Finally, it is also remarkable how little commentary was dedicated by $19^{\text {th }}$ century legal writers to the offence of false imprisonment.

In conclusion, the offence of false imprisonment was much simplified by the end of the $19^{\text {th }}$ century. Avail to it was also diminished. Finally, there was a marked tendency to treat false imprisonment as a species of assaultsomething which was only corrected by legal writers in the mid-20 $0^{\text {th }}$ century.

\section{False Imprisonment: $1883-1965{ }^{181}$}

\footnotetext{
172 Prior to 1829 , the reputation of police constables was very low and they got up to all sorts of nefarious activities of which falsely imprisoning people was likely one. See also Allen, n 85, p 96 (quoting House of Commons report).

${ }^{173}$ Lee, n 68, p 176 noted that, by 1829, there were 5 classes of peace officers (excluding special constables): (a) parochial constables, whon were elected annually in a parish or township and who served gratuitously; (b) their substitutes or deputies; (c) salaried bow street officers; (d) stipendiary police constables; (e) stipendiary water police. Of these (a)-(c) applied to London and its neighbourhood only.

${ }^{174}$ Ibid, pp 296-7, 'The office of high-constable (finally abolished in 1869) had long been purely nominal...' Lambard, n 71 (1599 ed), p 4 'The sundry names of constables, or high constables....and the diverse names also of constables, petty constables, tythingmen, borsholders, boroeheads, headboroes, chief pledges, and such other... are all (in effect) but two, that is to say, constables and borsholders: for these two words do contain as much as all the rest of those names, and to those two all the rest of them may be reduced...' (spelling modernized). See also, p 9 (the office of borsholders, tithingmen, headboroughs, boroughheads, third boroughs and chief pledges, is the same as that of petty constables).

${ }^{175}$ Lewis $v$ Cattle [1938] 2 KB 454,457 (every police officer holds the office of constable).

176 The last local police force (in Hove) ended in 1898

177 See McBain, n 48, pp 39-40.

${ }^{178}$ See the Constables Protection Act 1750, see n 151. See also Lee, n 68, p 159

${ }^{179}$ When did it become obsolete? P Colquhoun, A Treatise on the Police of the Metropolis ( $3^{\text {rd }}$ ed, 1796), pp 200-1 'However doubtful the utility of this ancient method of detecting offenders may be, in a great metropolis, in the present extended state of society, it is plain, that it has been considered as an important regulation of police so late as the $8^{\text {th }}$ George II (1735) since it was enacted in that year, (stat 8 George II, cap 16) that the constable who neglects making hue and cry, forfeits five pounds; and even the district is liable to be fined (according to the law of Alfred) if the felony be committed therein, and the felon escapes.' That said, one suspects that - even by 1735- it was rarely availed of.

${ }^{180}$ Lee, n 68, p 159.

181 JC Smith and B Hogan, Criminal Law (Butterworths, 1965) pointed out - in the Introduction to the first edition of their work - in the $20^{\text {th }}$ century, the principal university legal texts dedicated to criminal law comprised: (a) Kenny (see n 24); (b) Cross and Jones (see n 24) and (c) Glanville Williams, Criminal Law: The General Part $\left(2^{\text {nd }}\right.$ ed, 1961). Glanville Williams did not discuss false imprisonment (although he did in his later textbook, see $\mathrm{n} 24$ ( $3^{\text {rd }}$ ed, edited by Baker). For its part, Cross and Jones ( $2^{\text {nd }}$ ed, 1949), n 24 said almost nothing on false imprisonment save for, $\mathrm{p}$ 136, 'it may be observed that false imprisonment, which may be committed without any assault or battery, by unlawfully unlocking a person in a room, for instance, is a common law misdemeanour.' To the list of Smith \& Hogan might be added Russell $\left(1^{\text {st }}\right.$ ed 1819 , last ed, 1964), albeit this was then more a practitioner's work.
} 


\section{(a) Kenny (1902-66)}

Kenny, in the first edition of his Outlines on Criminal Law did not deal with the offence of false imprisonment beyond stating, in the context of assault, that:

To deprive another person of his liberty will usually involve touching or threatening to touch him: and thus the tort of false imprisonment usually involves an obvious assault. ${ }^{182}$

However, to treat false imprisonment as a form of assault is incorrect; it has long been a substantive offence in its own right. Further, false imprisonment does not necessarily involve either assault or battery. These points were made by Turner (in 1945). ${ }^{183}$ He stated, with reference to a discussion on assault:

It may be well at this point to refer to the crime of false imprisonment, for in some authorities it is confused with assault.

Indeed, false imprisonment is sometimes treated as though it were merely a special form of assault. Thus, in both Kenny and Stephen it is discussed only in connection with assault and not dealt with as a distinct and separate crime at all. This is strange, for long ago Coke pointed out ${ }^{184}$ that false imprisonment had been an indictable misdemeanour since Magna Charta, ${ }^{185}$ and neither he nor Comyns nor Blackstone identifies it with assault. Russell says, ${ }^{186}$ 'It usually, but not necessarily, involves an assault,' which is true, for in most instances where false imprisonment occurs, assault and battery will also in fact have been committed. Statements have, however, been made to the effect that mere wrongful deprivation amounts, per se, to an assault. Hawkins ${ }^{187}$ has been given as authority for this proposition. Hawkins' words are '...he who is threatened to be imprisoned by another has right to demand the surety of the peace; for every unlawful imprisonment is an assault and wrong to the person of a man', but as he proceeds to argue with reference to battery it would seem that he had in mind an imprisonment involving physical force, especially as when defining and discussing assault he says nothing of false imprisonment. Nevertheless in Pocock v Moore ${ }^{188}$ where the plaintiff, being given into the custody of a constable and being called upon to accompany him, had done so without being touched, Abbott LCJ said '.... if the constable tell the party charged that he must go with him, on which the other, in order to prevent the necessity of actual force being used, expresses his readiness to go, and does actually go, this is an imprisonment. Then, as every false imprisonment includes an assault, the plaintiff may recover on the count for a common assault.' His Lordship's words would seem to indicate that he envisaged a threat by the constable of the application of force, and if so this case is within the ordinary principles of assault. 189

In the case of $R v$ Linsberg ${ }^{190}$ an accoucheur had been prevented from leaving his patient by being locked in the room. He was not touched. There were three counts in the indictment, one for assault and false imprisonment, the second for false imprisonment, and the third for common assault. From the report it may be suggested, with respect, that neither the counsel, nor the judge, appreciated that false imprisonment was itself an indictable misdemeanour. Counsel for the prosecutor said, '...the prisoner will plead guilty to the second count of the indictment, but that count, not alleging any assault and battery, does not charge an indictable offence.' Counsel for the Crown thereupon sought to establish that false imprisonment was assault, by reference to Pocock v Moore, ${ }^{191}$ Hunter $v$ Johnson ${ }^{192}$ and

\footnotetext{
${ }^{182}$ See eg. CS Kenny, Outlines of Criminal Law (13 ${ }^{\text {th }}$ ed, 1929), p 153.

${ }^{183}$ D Davies et al, The Modern Approach to Criminal Law (Macmillan,1945), chapter by JWC Turner, Assault at Common Law, pp 344-55.

${ }^{184}$ Reference was made to Coke, n 17, vol 2, p 55 (discussion on Magna Carta), see n 165. Also, to Comyns, see n 156.

${ }^{185}$ Reference was made to Magna Carta, c 29, see n 165.

${ }^{186}$ Reference was made to Russell, n 158 (9 $9^{\text {th }}$ ed, 1936), p 590.

${ }^{187}$ Reference was made to Hawkins, n 18, vol 1, ch 60, s 7 (see $3^{\text {rd }}$ ed, 1739).

188 (1825) Ry \& Mood 321 (171 ER 1035). The case concerned a trespass for an assault and false imprisonment, with a count for common assault. A constable was directed by the defendant to take the plaintiff on a charge of felony. The constable told the latter 'You must go with me.' The plaintiff did so without further compulsion. Held this was sufficient imprisonment to support an action and that the plaintiff's failing to prove imprisonment, he might recover on a count for common assault.

${ }^{189}$ In a fn he stated: 'The attention of the court does not seem to have been drawn to the case of Arrowsmith v Le Mesurier (1806) 2 Bos \& Pul (NR) 211 when Mansfield CJ ruled there could be an arrest without any physical touch.' See also J Oldham, The Mansfield Manuscripts (Univ of North Carolina Press, 1992), vol 2, ch 16 (for cases on false imprisonment which came before Mansfield CJ).

190 (1905) 69 JP 107 (false imprisonment without any belief of the existence of any legal authority, although no actual assault or battery took place, is an indictable offence).

191 See n 188.
} 
Hawkins. ${ }^{193}$ The Common Sarjeant, in summing up, said: ${ }^{194}$ 'A very important question arises in this case. Does false imprisonment without any actual assault and battery constitute an indictable offence? I am satisfied by the authorities quoted that the mere imprisonment is an assault and can be, and is in this case, an indictable offence.'

In each of the cases referred to in $R v$ Linsberg it will be found that the facts justify the conclusion that the accused person had presented the other party with the alternative of submitting quietly or of suffering the application of physical force and this is in effect a threat of physical force sufficient to amount to an assault on the general principles above stated. It is therefore submitted that the dicta of the authorities in dealing with false imprisonment necessitate no modification in these principles.

If a person were in a room, and another person, in order to keep him there, were secretly to lock the door from the outside, this would be false imprisonment, but to treat it as an assault would involve a divergence from the principles of assault laid down by all the authorities since Hawkins much more wide than the authority of Pocock $v$ Moore or $R v$ Linsberg, on the facts of these cases, could warrant. ${ }^{195}$

In the final edition of Kenny (in 1966), Turner made the same point:

False imprisonment is a specific crime at common law although its frequent association with assault and battery has tended

to obscure this fact, so that some writers have mistakenly treated it as a special instance of assault. It has, however, been an indictable misdemeanour from the earliest times. ${ }^{196}$

The confusion of false imprisonment with assault has produced statements which have the effect of treating false imprisonment as amounting to 'constructive assault' when in fact no assault or battery has taken place (as in $R v$ Linsberg, ${ }^{197}$ where an accoucheur was locked in a room with his patient so that he could not leave her, although he was neither threatened with any force or touched); or statements that 'every false imprisonment includes an assault'. ${ }^{198}$ Of course in very many cases of arrest and imprisonment the arresting officer has plainly intimated that he is about to take the prisoner by force, and this is sufficient to constitute assault by the ordinary principles even if the man goes quietly without in fact being touched. ${ }^{199}$ (wording divided for ease of reference)

\section{(b) Harris (1950) \& Russell (1964)}

Where false imprisonment was discussed in $20^{\text {th }}$ century texts, it was, generally, in little detail. For example, Harris, Principles and Practice of the Criminal Law (1950), provided:

False imprisonment is a common law misdemeanour, [fine and imp]; it may also be the subject of civil proceedings. The prosecution need only prove the imprisonment by the defendant, who must then show that it was justified...

Every confinement of the person is an imprisonment, whether it be in a common prison or in a private house... or even by forcibly detaining one in the public streets. ${ }^{200}$ It must, however, amount to a total restraint of liberty for some time, however short; merely to prevent a person from going along a particular road or in a particular direction is not an imprisonment. ${ }^{201}$ But there may be an imprisonment although the person is not touched, but submits to the restraint, as, eg., if a person is told by a constable to go with him and obeys; and there may be a constructive imprisonment although the person imprisoned does not know that he is under restraint, as, eg, where, without knowing it, he is under the

\footnotetext{
192 (1884) 13 QBD 225 (since the Elementary Education Acts did not authorize the setting of lessons to be prepared at home by children attending a board school, the detention at school of a child after school hours by a master for not doing her homework was unlawful. It rendered the master who detained the child liable to be convicted of an assault).

${ }^{193}$ Hawkins, n 18, vol 1, ch 60, s 7 (he does not cite the edition but see eg. $3^{\text {rd }}$ ed, 1739).

194 At $\mathrm{p} 108$.

195 See Davies, n 183, pp 350-1.

${ }^{196}$ He cited Coke, n 17, vol 2, p 55 who refers to Magna Carta, c 29, see n 165. Turner also cited Comyns, see n 156 . Turner noted that 'Blackstone does not identify it with assault.' (this is correct, see $\mathrm{n}$ text to $\mathrm{n} 137$, although later writers of legal texts tended to do so).

197 (1905) 69 JP 107. Reference is also made to Arrowsmith v Le Mesurier (see n 189).

198 Reference is made to Pocock v Moore (see n 188) where Arrowsmith v Le Mesurier (see n 189) was not cited.

199 Turner, n 24, vol 1, p 222.

${ }^{200}$ Reference is made to Archbold.

${ }^{201}$ Reference is made to Bird v Jones, see n 158.
} 
restraint of constables stationed to prevent him from leaving a particular place. ${ }^{202}$ (wording divided for ease of reference)

Turner, in the final edition of Russell On Crime, in 1964 stated:

False imprisonment is unlawful total restraint of the liberty of another, whether by constraining him or compelling him to go to

a particular place or by confining him in a prison or police station or private place, or by detaining him against his will in a public place. It usually but not necessarily involves an assault or battery or some degree of threatened violence to the person; but the essential element in the offence is the unlawful detention of the person or the unlawful restraint of his liberty.

Such interference with the liberty of another's movements is unlawful unless it can be justified at common law or by statute as having been made under the lawful process or order of a court of justice or a competent official, or in the exercise of a lawful authority to arrest without such warrant or order in respect of an offence committed, or to restrain the person imprisoned from committing some crime or act dangerous to others...

False imprisonment is indictable at common law as well as actionable, and punishable by a fine and (or) imprisonment. But it is unusual to proceed by indictment for false imprisonment alone, though the fact of illegal detention may be stated as a matter of aggravation in an indictment for assault and battery.' ${ }^{203}$ (wording divided for ease of reference)

\section{(c) $\underline{\text { Smith \& Hogan (1965) }}$}

The first edition of Smith and Hogan (1965) noted as to false imprisonment:

False imprisonment, like assault and battery, is both a misdemeanour at common law and a tort. The civil remedy is much more commonly invoked and most of the cases on the subject are civil actions. But, as will appear, it is probable that there are some important distinctions between the crime and the tort. False imprisonment is committed where D unlawfully and intentionally or recklessly restrains P's freedom of movement from a particular place...

Though some of the older authorities speak of false imprisonment as a species of assault it is quite clear that no assault need be proved....[also] a battery is not necessarily an imprisonment...The imprisonment must be 'false', that is, unlawful... ${ }^{204}$ (wording divided for ease of reference)

In conclusion, $20^{\text {th }}$ century text writers re-asserted the accuracy of false imprisonment being a substantive offence in its own right, as opposed to being a species of assault or battery.

\section{Review of the Offence of False Imprisonment: 1240 - Date}

False imprisonment, as an offence, has been remarkably consistent and uncomplicated from the time of Bracton (c 1240). It has comprised the offence of illegally detaining a person and - while the caselaw and legal analysis has concentrated in particular on illegal detention in prisons, by police officers and in the stocks - it was established early on ${ }^{205}$ that it could apply anywhere - including in a public street or in the open. The only 'glitches' that have occurred in the offence seem to be as follows:

- Confusion with Assault and Battery. Not before, but after, Blackstone wrote on false imprisonment (in 1768), false imprisonment was often treated by legal writers as a species of assault (or battery). This may have arisen from judicial statements that every false imprisonment was an assault. Not only was (and is) this legally incorrect - since false imprisonment can be committed without any assault or battery - but it ignores the fact that false imprisonment, at least by the time Bracton wrote (c.1240), was treated as a substantive offence in its own right;

- Misleading Description. The reference to 'False Imprisonment' has been mis-leading for too long. 'False' is no more than the old Anglo-Norman (Law French) term for illegal or unlawful and, thus, when the former was no longer used, it would have been better to call it 'Illegal Imprisonment'. Further, 'Emprisonment' which - in early medieval times - would have connoted some form of detention within

\footnotetext{
${ }^{202}$ Ed. AM Wilshere (Sweet \& Maxwell, 1950), p 285.

${ }^{203}$ Turner, n 24, vol 1, pp 690-1.

${ }^{204}$ JC Smith \& B Hogan, Criminal Law (Butterworths, 1965), pp 277-8. There is a useful analysis of the caselaw. It may be noted that the wording in the text was little changed by the $11^{\text {th }}$ edition (2011).

${ }^{205}$ See $n 104$ (Thorpe CJ in a case in 1348).
} 
a prison as we know it, is also misleading, since the offence can be committed in the open air. The key word, then, is 'detention'. Thus, it would have been (and is) more helpful to refer to 'Illegal Detention' - as to opposed to 'False Imprisonment';'

- Legal Custody. Since the offence of false imprisonment comprised (until recently) a reference to unlawful detention in prisons and by police constables, its caselaw and analysis has concentrated on whether the custody was legal or not. Given this, it would have been useful by the early $20^{\text {th }}$ century, to codify - not just the offence - but also to clarify that it cannot be committed when a person is lawfully held in custody. Also, specifying what 'custody' includes. This would then dovetail with the law on escape, prison breach and rescue.

\section{False Imprisonment - Archbold \& Modern Texts}

\section{(a) Archbold - 2014}

In modern times, the offence of false imprisonment is defined as an unlawful detention. Thus, Archbold (2014) states:

False imprisonment consists in the unlawful and intentional or reckless restraint of a victim's freedom of movement from a particular place - it is unlawful detention which stops the victim moving away as he or she would wish to move. ${ }^{206}$

Archbold also notes the following:

- Parental Custody. A parent will seldom be guilty of this offence in relation to his (or her) child since the sort of restrictions imposed upon children are usually well within the realm of reasonable parental discipline and are, therefore, not unlawful. However, there are many ways in which the prosecution might prove 'unlawfulness' eg. (a) the existence of a court order and detention by the parent contrary to that order; (b) detention for such a period or in such circumstances as to take it out of the realm of reasonable parental discipline; whether that stage has been reached is a matter for the jury to decide provided that there is evidence fit for them to consider. Reference is made to $R v$ Rahman; ${ }^{207}$

- $\quad$ Acquittal or Expiry of term of Imprisonment. Archbold refers to Mee v Cruickshank (1902) ${ }^{208}$ and to Migotti $v$ Colvill (1879). ${ }^{209}$ The detention of a man on a warrant or process which is regular in form is unlawful if the warrant is executed at an unlawful time (such as in the case of civil process, on a Sunday) or in a privileged place (such as a royal court of justice or on a person privileged from arrest);

- Confinement. Archbold states: 'Every confinement of the person is an imprisonment, whether it is in a common [ie. public] prison or in a private house, or even in forcibly detaining a person in the public streets.' Reference is made to Coke ${ }^{210}$ - although this is very dated since the stocks and franchised prisons Coke refers to, no longer exist. Archbold also states that merely preventing a man from proceeding along a particular way, if, without going along that way, he may still get to his desired destination, is not an imprisonment, reference being made to Bird v Jones (1845); ${ }^{211}$

- Detention - Court Order. Archbold states: 'Detention to a specific order of a court is not actionable if the exigency of the order or warrant is disobeyed and the order is valid on the face of it. ${ }^{, 212}$ Reference

\footnotetext{
${ }^{206}$ Archbold, n 4, para 19-417. See also Blackstone CP, n 23, para B2.74-7 'False imprisonment is a common-law offence, but is not often charged. It is much more common as a civil action in tort. The overlap with kidnapping and child abduction means that those offences are more likely to be charged than a simple false imprisonment... [It] is triable only on indictment. It is a class 3 offence... The maximum penalty is at large (common law offence),'

${ }^{207} 81 \mathrm{Cr}$ App R 349 (considering $R v D$ [1984] AC 778). A Bangladeshi father abducted his daughter against her will with intent to take her to her country of origin. Held that, where a parent restrained a child's freedom of movement, it was false imprisonment if the restraint was unlawful. Unlawfulness was not restricted to cases where the parent acted in contravention of a court order. It included cases where the detention was for such a period - or in such circumstances - to take it out of the realm of reasonable parental discipline, which was a matter for the jury to determine. Blackstone $\mathrm{CP}, \mathrm{n} 23$, para B2.78.

20820 Cox CC 210 (the further detention of a prisoner after his acquittal and the court telling him that he was discharged was unlawful).

${ }^{209} 4$ CPD 233 (whether prisoner had been detained after his term of imprisonment had expired. How a calendar month was calculated). Cf Coke, n 17, vol 2, p 52 (published 1641) 'Imprisonment does not only extend to false imprisonment, and unjust, but the detaining of the prisoner longer than he ought, where he was at the first lawfully imprisoned...If the sheriff, or gaoler detain a prisoner in his gaol after his acquittal, unless it be for his fees, this is false imprisonment' (commenting on Magna Carta, c 29), see n 165.

${ }^{210}$ Coke, n 17, vol 2, p 589, see text to ns $106 \& 108$.

${ }^{211}$ See n 158

212 Archbold, n 4, para 19-332.
} 
is made to Greaves $v$ Keene (1879) ${ }^{213}$ and to Henderson v Preston (1888). ${ }^{214}$ Also, where a warrant is issued, but it is used merely as a summons, and no arrest is made on it, and the party goes voluntarily before the magistrate, this is not an imprisonment. Reference is made to Arrowsmith $v$ Le Mesurier (1806) 215 and Berry $v$ Adamson (1827); ${ }^{216}$

- $\quad$ Assault. An act of false imprisonment may amount to an assault, the offence may be committed by mere detention without violence. Reference is made to $R v$ Linsberg (1905) ${ }^{217}$ and Hunter v Johnson $(1884)^{218}$

\section{(b) Other Modern Texts on Criminal Law}

Apart from Archbold, most modern texts on criminal law do not deal with false imprisonment. ${ }^{219}$ Two that do, are Baker and Ormerod. Baker, Textbook on Criminal Law (2012) stated:

False imprisonment is the third traditional species of criminal trespass to the person, the other two being assault and battery (psychic and physical assault). It is a common law offence: but it differs from some common law offences in that no statute provides a ceiling to the possible punishment. ${ }^{220}$ It is, therefore, punishable with imprisonment and fine at discretion. Proceedings for the offence are not brought lightly, because it is punishable only on indictment.

What is false imprisonment? This is an archaic name for the unlawful detention of a person. It usually involves the application of force to the body, when it amounts also to a physical assault. But false imprisonment is committed by a person who unlawfully turns the key on someone who is already in the room; and here there is no assault. ${ }^{221}$ Logically, such an act should not have been regarded as falling within the notion of a trespass of the person, but it was made to do so $^{222} \ldots$

False imprisonment is a total restraint of liberty, but it may be committed without physical detention for example, by compelling the victim to go to a particular place ...223 (wording divided for ease of reference)

Baker also noted that prosecutions for false imprisonment are uncommon, and that the civil option tends to be preferred. ${ }^{224}$ Smith and Hogan's, Criminal Law (2011) stated:

False imprisonment, like assault and battery, is both a crime at common law and a tort. The civil remedy is commonly invoked and most of the reported cases on the subject are civil actions, but it features as a count in many indictments...there are some important distinctions between the crime and the tort. False imprisonment is committed where D unlawfully and intentionally or recklessly restrains V's freedom of movement from a particular place without lawful justification. 'Imprisonment' is probably a wider term than, and includes, 'arrest'. ${ }^{225}$

\footnotetext{
213 (1879) 4 ExD 73. The plaintiff was detained for more than a year in custody for a debt pursuant to an order issued by a court officer (a solicitor) which had been improperly signed and issued. Kelly CB at $\mathrm{p} 75$ 'I should be glad if the legislature had pronounced how, in the case of an officer of the court committed for disobedience to an order or other contempt, his imprisonment is to last, but no such law exists.'

21421 QBD 362. A prison governor is protected when obeying a warrant of commitment valid on the face of it. An action of false imprisonment will not lie against him for the detention of a prisoner pursuant to the same.

215 See $n 189$.

${ }^{216} 6$ B \& C 528 (108 ER 546). A sheriff's officer to whom a warrant on a writ against A was delivered, sent a message to A asking him to fix a time to call and get bail. A did so. Held this was not an arrest and that an action for malicious arrest would not lie against a party suing out the writ, although he had no cause of action. This case followed Arrowsmith, see n 189.

${ }^{217}$ See $\mathrm{n} 190$.

${ }^{218}$ See n 192.

${ }^{219}$ See $\mathrm{n} 24$. This is understandable since many are student texts or seek only to cover the principal criminal offences, not the whole law.

${ }^{220}$ See also $n 206$.

${ }^{221}$ He cites $R v$ Linsberg, see n 190.

${ }^{222}$ Baker, Glanville Williams Textbook on Criminal Law ( $3^{\text {rd }}$ ed), para 9-101 et seq. For a shorter analysis, see $2^{\text {nd }}$ ed (1983), pp 217-8. See also G Williams, Requisites of a Valid Arrest [1954] Crim LR, pp 11-2.

${ }^{223}$ Ibid, para 9-103.

${ }^{224}$ Ibid, para 9-101. Also, para 9-104 'Prosecutions for false imprisonment are uncommon because the damages obtainable in a civil action are likely to be far higher than the criminal penalty. Another effective remedy is an application for a writ of habeas corpus, and anyone who impedes the process on habeas corpus can be committed to prison for contempt of court.'

${ }^{225}$ D Ormerod (ed), Smith and Hogan's Criminal Law $\left(13^{\text {th }}\right.$ ed, 2011), p 678. For this proposition, Ormerod cites Rv Rahman (1985), see n 207 and Brown [1977] Crim LR 291. This statement would appear indubitably correct since Bracton (c.1240) took imprisonment to cover arrest, as well as detention. See $\mathrm{n} 54$.
} 
Smith \& Hogan also noted that 'imprisonment' could include anywhere and analyses the nature of 'imprisonment' in some detail. ${ }^{226}$ Also,

Though some of the older authorities speak of false imprisonment as a species of assault, it is quite clear that no assault need be proved...A battery is not necessarily an imprisonment. ${ }^{227}$

It also commented that:

The imprisonment must be 'false', that is unlawful. A convicted person sentenced to imprisonment may be lawfully confined in any prison and, as against prison officers so confining him in good faith, he has no 'residual liberty.'...A parent may lawfully exercise restraint over a child, so long as he remains within the bounds of reasonable parental discipline and does not act in contravention of a court order, or the Children Act 2004, s 58...The question of false imprisonment most commonly arises with the exercise of powers of arrest. If such powers are exceeded, there is false imprisonment... ${ }^{228}$

\section{(c) Defences}

In the first edition of his work in 1822, Archbold stated:

The defendant must either prove that he did not did imprison [the victim] at all, or he must justify the imprisonment. The

grounds on which an imprisonment can be justified, may be considered under the following heads:

Archbold then set these out: being: (a) arrest under civil process (that is, pursuant to a court order); (b) arrest under warrant from a JP; (c) arrest without a warrant; (d) arrest for contempt of court; (e) arrest after an escape. ${ }^{229}$ Presently, Archbold (2014) states the following:

An imprisonment or detention will be lawful if it is in pursuance of the sentence of a court, if it is an exercise of lawful restraint, or if it results from the exercise of a power of arrest conferred by law. In addition to these general justifications, there may be specific statutory justification for a particular restraint upon an individual's identity, such as the MHA [Mental Health Act] 1983 or the Merchant Shipping Act 1995, s 105. Of all the heads of justification, that which is likely to be most significant in practice is the exercise of the lawful power of arrest...

As to lawful restraint other than by way of arrest, a parent may restrain a child and a householder is entitled to use reasonable force to defend his property, and for this purpose he is entitled to be judged on the basis of the facts as he believed them to be, however unreasonably. It is unusual to proceed by indictment for false imprisonment alone, though the fact of illegal detention may be stated as a matter of aggravation in an indictment for assault and battery. ${ }^{230}$

In respect of defences, Archbold adopts the same approach as in 1822 referring to:

(a) arrest under civil process, which it notes is largely abolished; ${ }^{231}$

(b) statutory arrest under criminal process - pursuant to a warrant; ${ }^{232}$

(c) arrest under criminal process - without a warrant;

(d) statutory powers. ${ }^{233}$

\footnotetext{
${ }^{226}$ Ibid, p 679 'The 'imprisonment' may consist in confining V in prison, a house, even V's own house, a mine or a vehicle; or simply in detaining $\mathrm{V}$ in a public street or any other place.'

${ }^{227}$ He cites Linsberg (see n 190) and Bird and Jones (see n 158) respectively.

${ }^{228}$ Ormerod, $\mathrm{n} 225$, pp 682-3. He then discusses various powers of arrest.

${ }^{229}$ The caselaw is obsolete and so I do not set it out. Archbold also mentioned 'arrest under other authority' (feme covert, impressment etc). However, this is also obsolete.

${ }^{230}$ Archbold, n 4, para 19-425. Reference is made to $R v$ Faraj [2007] 2 Cr App R 25 (householder entitled to use reasonable force to detain a person believed to be a burglar). The Merchant Shipping Act 1995, s 105 (master's power of restraint) provides that 'The master of any United Kingdom ship may cause any person on board the ship to be put under restraint if and for so long as it appears to him necessary or expedient in the interest of safety or for the preservation of good order or discipline on board the ship.'

${ }^{231}$ Ibid. 'Arrest under civil process is now abolished, except: (a) for contempt of court of a civil nature; and (b) in the circumstances and subject to the restrictions set out in the Debtors Act 1869, ss 4-6, and the Administration of Justice Act 1970, s 11. See also the Family Law Act 1996, s 47.'

${ }^{232}$ Ibid. Archbold refers, in particular, to the Magistrates Courts Act 1980 (in respect of magistrates' courts) and the Senior Courts Act 1981, ss 80-1 (in respect of the Crown Court).

${ }^{233}$ Reference is made to the PACE Act 1984, Pt 3. See Archbold, n 4, para 19-431.
} 
It may be noted that all these cases relate, with one or two exceptions, to when a person is in the custody whether that of a prison governor or officer, police constable or the court. Therefore, in any modern formulation of false imprisonment, it would useful to specify what is 'custody' since this will cover most of the caselaw and, obviously, if a person is in lawful custody, the offence of false imprisonment cannot be committed. ${ }^{234}$

\section{Statutory Offence of False Imprisonment - Possible Wording}

It is asserted that an offence of false imprisonment is still needed, since the same is not otherwise an assault, battery or kidnapping. It is also asserted that:

- This offence should now be statutory;

- To make it more intelligible to lawyers and laymen in modern times, the offence should be called

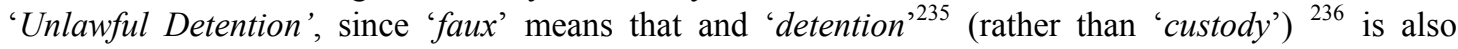
appropriate;

- The level of punishment should be clarified. ${ }^{237}$ At present, the term of imprisonment that can be imposed is open-ended. ${ }^{238}$ So too, the level of fine.

Possible wording for the statutory crime is provided in Appendix A. The definition of 'custody' (the word 'detention' could be used alternatively) would be the same as that in respect of escape, prison breach and rescue. ${ }^{239}$ This would dovetail these offences. As to the meaning of 'unlawfully detain', the latter word is sufficiently wide - even in common parlance - to cover 'retention' and 'restraint.' Further, regard may be had to prior definitions of this offence. I do not refer to those prior to Pulton (1609) since they add little. However, I embolden those which refer to 'restraint' and those to 'detention':

- Pulton (1609). 'if one person do arrest, imprison, or otherwise restrain another person of that liberty, without sufficient and lawful cause, the party grieved may have an action of false imprisonment.' (see 5);

Blackstone (1768) 'To constitute the injury of false imprisonment there are two points requisite: 1 . The detention of the person; and, 2. The unlawfulness of such detention. Every confinement of the person is an imprisonment, whether it be in a common prison, or in a private house, or in the stocks, or even by forcibly detaining one in the public streets... Unlawful, or false, imprisonment consists in such confinement or detention without sufficient authority.'(see 5);

- Buller (1788) 'Every restraint of a man's liberty under the custody of another, either in a gaol, house, stocks, or in the street, is in law an imprisonment; and whenever it is done without a proper authority, is false imprisonment...' (see 5);

- $\quad$ Russell (1819) 'To constitute the injury of false imprisonment, there must be an unlawful detention of the person.' (see 6b);

- Gabbett (1843). 'Unlawful imprisonment...to constitute this injury, there must be unlawful detention of the person...'( $($ see $6(\mathrm{c}))$;

- $\quad$ Russell (ed Turner, 1964) 'False imprisonment is unlawful total restraint of the liberty of another, whether by constraining him or compelling him to go to a particular place or by confining him in a

\footnotetext{
234 'Lawful' is not the same as 'legal' since the latter has the connotation (in modern parlance) of it being the custody of a legal officer (police constable, prison officer etc). However, being in such custody can still be unlawful, in that it is contrary to law.

${ }^{235} \mathrm{OED}, \mathrm{n} 36$ (detention) 'from detinere, to detain. The word is late in Eng[lish] and may have been taken immed[iately] from L [Latin]. The action of detaining, or condition of being detained. 1. keeping in custody, or confinement; arrest. ...3. Keeping in a place; holding in one's possession or control; retention. 4. A keeping from going on or proceeding; hindrance to progress; compulsory delay.'

${ }^{236}$ Ibid, "Custody' custodia [Latin] guarding, keeping. custos, custodem, keeper. 1. Safe keeping, protection, defence; charge, care, guardianship. 2. The keeping of the officers of justice (for some presumed offence against the law); confinement, imprisonment, durance.'

${ }^{237}$ The punishment should be less than that of kidnapping.

${ }^{238}$ Greaves $v$ Keene (1879) 4 ExD 73, per Kelly CB at $\mathrm{p} 75$ 'I should be glad if the legislature had pronounced how, in the case of an officer of the court committed for disobedience to an order or other contempt, his imprisonment is to last, but no such law exists.'

${ }^{239}$ See McBain, n 1, p 172 (proposed statutory formulation of offence) 'Custody' includes where a person is in custody when: (i) under arrest; (ii) held in a police station; (iii) awaiting trial; (iv) awaiting sentence; (v) serving a sentence; (vi) in transit to, or from, a designated place (including a prison van); (vii) attending a criminal court for trial or sentence; (viii) confined in any designated place; (ix) under the control, of the governor of a designated place; (x) under the control, of a prison officer or other officer of a designated place (and whether inside, or outside, a designated place for the purpose of work or for any other reason); (xi) while being taken or kept in custody in any place to which he is required or authorised under any criminal legislation.
} 
prison or police station or private place, or by detaining him against his will in a public place.' (see 7(b));

- Smith \& Hogan (1965) 'False imprisonment is committed where D unlawfully and intentionally or recklessly restrains P's freedom of movement from a particular place...' (see 7(c)); ${ }^{240}$

- $\quad$ Archbold (2014) 'False imprisonment consists in the unlawful and intentional or reckless restraint of a victim's freedom of movement from a particular place - it is unlawful detention which stops the victim moving away as he or she would wish to move.' (see 9(a));

- Baker (2012) 'What is false imprisonment? This is an archaic name for the unlawful detention of a person.' (see 9(b)).

The key words, as Blackstone identified and which have been often repeated, are 'unlawful' and 'detention'. Others have used the word 'restraint' (see above). However, this implies some physical act on a person, when there need not be. Writers prior to Blackstone tended to focus on imprisonment and arrest. However, these were (are are) simply examples of detention; they do not constitute the full ambit of the offence, not then and, certainly, not today.

One other matter may be referred to. In past cases, there was uncertainty as to whether arrest, per se, constituted detention (ie. a police constable or ordinary citizen requiring a person to come with him, without the consent of that person but under a sense of compulsion). Today, 'arrest' - with or without warrant and whether any physical restraint is imposed or not - should comprise 'custody.'

\section{Conclusion - False Imprisonment}

Too much of our law (including our criminal law) is out of date. Our law needs to reflect modern modes of language and social conditions. In the case of false imprisonment, modernising the law would not appear to be difficult.

- The offence should be that of the 'unlawful detention of a person;'

- If the detention is lawful detention - as in the case where a person is in lawful custody (including prison and arrest which are, by far, the most common instances of it down the centuries) - then such detention is not an offence;

- Also, 'detention' is a word that does not (unlike restraint) imply any physical control (including any assault or battery) which was never a pre-requisite of the offence anyway.

\section{Refusing to Assist a Police Officer}

Refusing to assist a police officer in the execution of his duty in seeking to prevent a BOTP is also a common law offence. One which - like false imprisonment - has a long history.

- This offence has scarcely been considered in legal texts on criminal law. Usually, a few lines have been dedicated to it at most;

- This is likely because its origins are obscure and such a duty likely derives from Anglo-Saxon law, when the precursor to the police constable (called the headborough or borsholder) existed and when the concept of hue and cry first arose.

This article considers this offence and argues that it, also, should be made statutory. First, however, it is useful to commence with a modern statement on this offence, in one of the few texts on criminal law which deal with it. Archbold (2014) provides:

Refusing to aid and assist a constable in the execution of his duty, in order to preserve the peace, is an indictable misdemeanor at common law. In order to support such an indictment, it must be proved that the constable saw a [BOTP] committed; that there was a reasonable necessity for calling upon the defendant for his assistance; and that when duly called on to do so, the defendant, without any physical impossibility or lawful excuse, refused to do so. And it is no defence that the single aid of the defendant could have been of no avail: $R v$ Brown (1841)...

An indictment for refusing to assist a constable in the execution of his duty, and to prevent an assault made upon him by persons in his custody on a charge of an offence made with intent to resist their lawful apprehension, is sufficient without stating how the apprehension became lawful; and it is

\footnotetext{
${ }^{240}$ Substantially repeated in the $11^{\text {th }}$ ed (see 9(b)) 'False imprisonment is committed where D unlawfully and intentionally or recklessly restrains $\mathrm{V}$ 's freedom of movement from a particular place without lawful justification...'
} 
sufficient if it states a refusal to assist, without the further allegation that the prisoner did not, in fact, assist: $R v$ Sherlock (1866). ${ }^{241}$ (wording divided for ease of reference)

The kernal of the offence,therefore, is a refusal to 'assist a police constable in the execution of his duty, in order to preserve the peace.' However, Archbold fails to analyse the origin of this offence. Nor on whom the obligation is placed. Consideration will now be given to this.

\section{Refusing to Assist - Anglo-Saxon Origins}

As far as I aware, no text on criminal law since Staunford's Les Plees del Coron (1577) ${ }^{242}$ - which is accredited with being the first text on criminal law - identifies an originating case for this offence. Nor do (it appears) the Abridgments (c. 1490-1822) ${ }^{243}$ the Yearbooks (1268-1535), ${ }^{244}$ the Selden Society reports ('SS'), ${ }^{245}$ the English Reports ${ }^{246}$ or other early material.

- This would not seem especially surprising since police constables as we know them, probably only came into existence c.1285 or 1242 (see 4(c)); yet their precursors (headboroughs, borsholders) existed in Anglo-Saxon times. However, the precise position as to the law as it existed over a 1000 years ago in England is obscure;

- That said, some legal acts and precepts continued after the Norman Conquest of 1066 and they had become, by then, deeply embedded into the legal and social fabric of society. Therefore, it is possible to make some statements - for example, with regard hue and cry - with a fair degree of certainty that they are accurate.

As for life in Anglo-Saxon times, it was harsh. There was a constant threat of invasion and civil disruption on a major scale. There was also a high level of personal violence. As a result, mutual protection associations were formed at a local, and a national, level.

- National Obligations. At a national level, subjects were obliged to satisfy the trinoda necessitas (the 'threefold necessity'). Thus, they were obliged to assist with: (a) the suppression of internal insurrection; (b) the repelling of foreign invasion; and (c) the construction of bridges. ${ }^{247}$ This threefold legal obligation was likely based on allegiance to the sovereign. That is, in return for protection by the same, the subject pledged allegiance to the sovereign which was manifested (in part) by performing these obligations. $^{248}$ In the case of (a) and (b), these obligations may still exist - to some extent; ${ }^{249}$

- Local Obligations. As to protection on a local scale, the ability of a sovereign to remain on his throne was dictated - in large measure - in not only be able to thwart threats from abroad or from other potentates (England was not united until late in Anglo-Saxon times), but also in maintaining public order in the many small villages and towns throughout England. His ability to do this was encapsulated in the 'king's peace' - an expression reflecting the extent to which his legal powers, in practice, could be enforced. ${ }^{250}$ In order to achieve this, as previously noted (see 4(d)), there was a system of mutual

\footnotetext{
${ }^{241}$ Archbold, n 4, para 19-336.

${ }^{242}$ See $\mathrm{n} 12$.

${ }^{243}$ See ns 25-34.

${ }^{244}$ The best hardcopy edition is that of Maynard (Vulgate, 1678), reprinted by LBE. See also Seipp Index, n 97.

${ }^{245}$ Vols 1-128. See selden.society.com. Also www.wshein.com/ which has put SS vols 1-99 online.

246 These are now online. See Sweet \& Maxwell and Butterworths websites.

${ }^{247}$ See generally, GS McBain, Abolishing Obsolete Crown Prerogatives relating to Martial Law, Conscription \& Billeting (2012) International Law Research, vol 1, no 1, 13-62.

${ }^{248}$ See Calvin's Case (1608) 7 Co Rep (77 ER 377) 1a at 5a 'Protectio trahit subjectionem, et subjection protectionem' ('protection draws allegiance and allegiance draws protection).' See generally, GS McBain, Abolishing the Crime of Treason (2007) 81 ALJ, pp 28-9.

${ }^{249}$ The military obligation on subjects was institutionalized when William I (1066-87) instituted a system of land tenure based on military service. However, it became commuted to monetary payments (scutage) from the time of Henry II (1154-89) since professional soldiers were, generally, found to be of greater utility. This common law military obligation imposed on all subjects may still survive today, capable of being invoked by the Crown when the nation is in extreme necessity and the principle of 'suprema lex, salus populi' effectively prevails. See generally, McBain n 247, as well as fn 253 to the same.

${ }^{250}$ B O'Brien, God's Peace and King's Peace, The Laws of Edward the Confessor (Univ of Pennsylvania Press, 1999), p 169 quotes one of these laws as stating: 'There are many types of the king's peace: one is given by his hand, which the English call kings hand salde grid, another [is given] on the day on which he is first crowned - this one lasts for eight days; at Christmas eight days and eight days at Easter and eight at Pentecost; another is given by his writ; another which the four roads have, that is Watling Street, Fosse Way, Iknield Way, and Ermine Street, of which two extend for the length of the kingdom, the others across the width; another held by the bodies of water on which victuals are brought by ship to cities and boroughs from various places. Moreover, the peace of his hand, on the days of his coronation, and of a writ, are
} 
surveillance and policing - reflected in the grouping of subjects into units, in which they pledged their own and their neighbour's upholding of the king's peace. ${ }^{251}$ This was achieved and re-inforced by the giving of an oath or pledge (frank or peace pledge) in the presence of the king's officer - the shire reeve who later became the Norman sheriff. As the system became more institutionalised, frankpledge was performed at the same time when the sheriff came to judge criminal cases at the sheriff's tourn. And, with the franchising of the right to judge less important criminal matters to lords of the manor, frankpledge was performed at the court leet, the franchised criminal court. The result was that 'view of frankpledge', 'law day' and 'court leet' came to signify the same thing although, originally, frankpledge would specifically have referred to the oath as such. ${ }^{252}$

Giving an oath was one thing. How was it to be enforced in practice ? When considering later texts (from the $16^{\text {th }}$ century onwards) in relation to the offence of refusing to assist a police constable, they tended to cite this obligation very much in the context of:

(a) the obligation on subjects to participate in the hue and cry and the posse (see 14);

(b) the power of sheriffs and constables to arrest;

(c) the obligation on subjects to help suppress riots, routs, unlawful assemblies and affrays;

(d) legislation imposing an obligation on subjects to assist the police powers (JPs's, sheriffs, constables etc).

Further, as the legal power of the high sheriff and his bailiffs to maintain the king's peace wained, that of JP's and constables increased.

In conclusion, slowly, the obligation to assist a constable in the specific instances of (a)-(d), evolved into that of a general duty imposed by the common law on a subject to assist a constable in order to preserve the king's peace (ie. public order or the criminal law). It is asserted that the latter was first formulated by legal writers, as opposed to deriving from any specific court case. This evolution will now be discussed.

\section{Hue and Cry - Obligation to Assist}

\section{(a) Anglo-Saxon Times}

The phrase 'hue and cry' is still used today. It likely derived from Anglo-Saxon times, although the expression itself may be Anglo-Norman, a reference to the 'harou'. ${ }^{253}$ Coke thought that it involved shouting and the blowing of a horn, for others to come to assist. ${ }^{254}$ The addition of the latter seems reasonable since a human shout would not, generally, carry very far. ${ }^{255}$

- As to when the hue and cry was employed one would surmise that - in early times, both Anglo-Saxon and Norman - it would have been used on all occasions where communal effort was needed to prevent a

under the judgment of the same penalty; similarly [the peace] of the four roads and the major waterways concerning assault.' See also P \& M, n 43, vol 1, pp 44-5 and Allen, n 85, passim.

${ }^{251}$ See 4(d).

${ }^{252}$ See GS McBain, Abolishing Various Obsolete Courts (2012) Coventry LJ, vol 17, no 1, pp 26-7.

${ }^{253}$ Thus, JA Everard, Le Grand Coutumier de Normandie (c.1250's) (Jersey and Guernsey Law Review Ltd, 2009), ch 70 (Of the Clamour for Robbery), p 304 'In cases of robbery, the clamour is made in this form: I complain of Titio who assaulted me feloniously in the peace of God and of the lord king, and wounded me. He caused this wound to me and [drew] this blood and he took my cape in robbery, when it fell to me to cry 'harou' [under me harou oportuit clamare].'

${ }^{254}$ Coke, n 17, vol 3, p 116 ' [Of hue and cry] The one being an expression of the other. For huer in French to is to hoot or shout, in English to cry.' Ibid, vol 2, p 172 'Note, in legal understanding hue and cry is all one; in ancient records they are called hutesium et clamor, and here cry is used for both. And this hue and cry may be by horn and by voice, avec hue et crie de corne et de bouche.' (spelling modernized). Glanvil (c. 1189), n 64, pp 174-5 referred to hue and cry as 'clamor popularis'. Bracton, $\mathrm{n} 8$, vol 2, pp 350, 442 called it 'huthesium et clamorem'. Britton (c.1290), n 9, p 42 'And for the maintaining of peace, we will that when a felony is committed, every one be ready to pursue and arrest the felons, according to our Statutes of Winchester [see n 267], with the company of horns and voices from township to township...' See also OED, n 36 (hue and cry) and, generally, Coke, n 17, vol 2, pp 170-3.

${ }^{255}$ Burn (1820), n 14, vol 2, p 812 'since it appeareth by the old books...that hue and cry was anciently by horn and by voice, it may seem that these two words are not synonymous, but that this hutesium or hooting is by the horn and crying by the voice; which also accordeth with the French word hutchet, which signifieth a huntman's horn; so that hue and cry in this sense will properly signify a pursuit by horn and by voice...And this blowing of a horn, by way of notice or intelligence, in other cases as well as in the pursuit of felons, seemeth to have been in use of very ancient time; for amongst the laws of Eihtred [Wihtred] king of Kent [693-725], in the year 696, this is one 'if a stranger go out of the road, and neither shout nor blow a horn, he shall be taken for a thief.' Cf. FL Attenborough, The Laws of the Earliest English Kings (NY, 1963), laws of king Ine (king of Wessex, 688-726), p 43 'If a man from afar, or a stranger, travels through a wood off the highway and neither shouts nor blows a horn, he shall be assumed to be a thief, and as such may be either slain or put to ransom.' 
[BOTP]. That is, when serious crimes (felonies) or violence involving a number of people (such as riots, routs, unlawful assemblies and affrays) were beyond the power of a single law enforcer (whether a sheriff, his underlings, a headborough or a constable) to quell and it was necessary to call on the assistance of others to suppress the disturbance and arrest the offenders. In the case of felons - persons who could expect summary execution when caught - help would be required, in particular, to catch them;

- The participants in hue and cry were those who had given the oath of frankpledge (peace pledge). They comprised able-bodied males over the age of 12 who had pledged to keep the peace. As a result, they were the persons obliged by their oath to assist the law enforcers.

In Anglo-Saxon times, it also seems clear that a person who neglected to participate in hue and cry, when required to do, was liable to a fine, at least. Thus, the laws of Aethelstan (927-39) provided that 'every man who neglects to give such help beyond the border shall forfeit 30 pence or an ox.' ${ }^{256}$ Similarly, the laws of Edmund I (939-46), stated the obligation as to the catching of thieves:

That men go without delay in pursuit of thieves. If the need is urgent, the chief official of the hundred shall be informed, and shall forthwith inform the chief officials of the tithings, and all shall go forth, as God shall direct them, until they succeed in coming upon the thief...And whosoever neglects this, and ignores the authority of the hundred - and the charge is established against him subsequently - shall pay 30 pence to the hundred, and on the second occasion 60 pence, half to the hundred and half to his lord. If he does it a third time, he shall pay half a pound. On the fourth occasion he shall suffer the loss of all that he possesses and be outlawed, unless the king allow him to remain in the country.' 257

Thus, hue and cry was the frankpledge in action - a vital means of maintaining the king's peace (ie upholding the criminal law).

\section{(b) Anglo-Norman Times}

Considering the period prior to Edward I (1272-1307), Pollock and Maitland stated:

We have now to speak of the various processes which the law employs in order to compel men to come before its courts. They vary in stringency from the polite summons to the decree of outlawry. But first we must say a word of an offshoot of outlawry, of a species of summary justice that was still useful in the thirteenth century. When a felony is committed, the hue and cry (hutesium et clamor) should be raised. If, for example, a man comes upon a dead body and omits to raise the hue, he commits an amerceable offence, besides laying himself open to ugly suspicions. Possibly the proper cry is 'Out' 'Out' and therefore it is uthesium or hutesium. ${ }^{258}$ The neighbours should turn out with the bow, arrows, knives, that they are bound to keep and, besides much shouting, there will be horn blowing; the 'hue' will be 'horned' from vill to vill.

Now if a man is overtaken by hue and cry while he has still about him the signs of his crime, he will have short shrift. Should he make any resistance, he will be cut down. But even if he submits to capture, his fate is already decided. He will be bound, and, if we suppose him a thief, the stolen goods will be bound on his back. He will be brought before some court (like enough it is a court hurriedly summoned for the purpose), and without being allowed to say one word in self-defence, he will be promptly hanged, beheaded or precipitated from a cliff, and the owner of the stolen goods will perhaps act as an amateur executioner. ${ }^{259}$ (wording divided for ease of reference)

Pollock and Maitland thought the process of hue and cry had it its origin in the days when a criminal taken in the act, was an outlaw. ${ }^{260}$ Being outside the law, the 'out law' was subject to summary justice (lynch law) and could be executed then and there. Although Pollock and Maitland noted that hue and cry was generally used against felons (or suspected felons) and outlaws, they also noted it was not confined to cases of murder and theft

\footnotetext{
${ }^{256}$ Attenborough, n 255, p 165.

${ }^{257}$ Robertson, n 86, p 17. Ibid, p 189, laws of Canute (1016-35) 'if anyone hears the hue and cry and neglects it, he shall pay the fine for insubordination to the king, or clear himself by the full oath.' Also, p 275 (so-called Laws of William I) 'if anyone hears the hue and cry and neglects it, he shall pay the fine for neglecting it to the king, or clear himself.'

${ }^{258}$ P \& M, n 43 vol 2, p 579, n 1 'The famous Norman Haro seems to mean Hither.'

${ }^{259}$ Ibid, pp 578-9.

${ }^{260}$ Ibid, p 580. They state of outlawry in the period they were writing about, 'It was still the law's ultimate weapon'. Also, outlawry 'involved, not merely escheat and forfeiture, but a sentence of death. If the outlaw was captured and brought before the justices, they would send him to the gallows so soon as the mere fact of outlawry was proved.'
} 
and they cite one of forgery. ${ }^{261}$ Thus, somewhat akin to the development of the concept of the 'king's peace', hue and cry began to encompass lesser crimes as society advanced and greater attempts were made to control, and suppress, all forms of violence - especially communal violence.

\section{(c) Proclamation of 1195}

As to hue and cry by the $12^{\text {th }}$ century, Beard ${ }^{262}$ noted:

Henry II [1154-89] had placed the execution of his famous police measure, the Assize of Clarendon, in the hands of the sheriffs and royal justices. Following in part this Assize, Archbishop Hubert ${ }^{263}$ issued in 1195 a proclamation for the preservation of the peace. He sent through the realm the ancient oath requiring all men to observe the peace of the king and to assist in capturing all offenders against law and order. Knights especially assigned for the purpose were instructed to summon before themselves all men of fifteen years of age or over, and cause them to swear that they would not be outlaws, robbers, or thieves, or receivers and abettors of such, and furthermore that they would make pursuit pro toto posse whenever hue and cry was raised, and deliver all offenders to the knights assigned to receive them. The knights in turn were to surrender the prisoners into the hands of the sheriffs for safe-keeping. ${ }^{264}$

The form of this Proclamation of 1195 is said to have been as follows:

That all subjects of the kingdom of England [omnes homines regni angliae], shall, to the best of their power, keep the peace of their lord the king; ${ }^{265}$ that they shall not be thieves or robbers, not yet harbourers of them, nor shall in any way abet them; and that whenever they shall be able to know of any malefactors of that character, they shall, to the best of their ability, endeavour to take them, and deliver them up to the sheriffs, and they shall on no account be liberated but by the lord the king, or his chief justice; and if they shall not be able to arrest them they shall give notice of them, whoever they may be, to the bailiffs of our lord the king.

When a hue and cry is raised for the pursuit of outlaws, robbers, thieves, or the harbourers of such, all shall join in pursuit of them to the best of their ability; and if they shall see any one, and it shall be clear that he has not joined in the said pursuit, or that he has, without permission, withdrawn himself therefrom, they shall take the such same persons, as though they were the offenders, and deliver them to the sheriffs, not to be set at liberty, but by the king, or by his chief justice.

Also, the knights who are appointed for that purpose, shall make all persons of their respective districts, of the age of fifteen years and upwards, appear before them, and shall make them swear that they will keep the peace of our lord the king, in manner above mentioned, and that they will not be outlaws, robbers, or thieves, nor the habourers of them, nor will they in any way abet them; and that they will, in manner above stated, make full pursuit of them and, if they shall take any one in the commission of an offence, will deliver them to the knights placed over them in their respective districts and for that purpose appointed, who shall deliver them into the custody of the sheriff;

and in like manner, on a hue and cry being raised for the purpose of pursuing the said offenders, if they shall see any person, or if it shall be known to them that any person does not join in the pursuit, or if he shall, without leave, withdraw himself from the pursuit, they shall take him as the offender, and deliver him to the aforesaid knights, for the purpose of being delivered into the custody of the sheriff, as though he were the offender himself; and he shall not be liberated, except by the command of our lord the king or his chief justice. (italics supplied) ${ }^{266}$

This obligation to participate in the hue and cry was encapsulated, nearly 100 years later, into the Statute of Westminster 1275, chapter 9 of which enjoined:

That all generally be ready [touts communement soient prestes] and apparelled, at the commandment

\footnotetext{
261 Ibid.

${ }^{262}$ CA Beard, The Office of Justice of the Peace in England (1904, rep. AMS Press, 1967), pp 178.

${ }^{263}$ Hubert Walter (d. 1205)(justiciar and archbishop of Canterbury), see Oxford English Dictionary of National Biography ('ODNB').

${ }^{264}$ Beard, n 262, p 18. He cites Stubbs, n 77, see ( $9^{\text {th }}$ ed), pp 257-8 who cites Roger of Hoveden, see $n 266$.

${ }^{265}$ RR Cherry, Lectures on the Growth of Criminal Law in Ancient Communities (Macmillan, 1890) pp 95-6, 'after the Norman Conquest, this limited geographical expression [ie. the king's peace] became that of a general king's peace during the reign of the sovereign. Thus, it became a matter of public order the breach of which arose from some act of violence. The need to show violence, in turn, became a legal fiction. Ibid, $p$ 96 'The allegation of a violation of the king's peace thus gradually became a mere fictitious averment to confer jurisdiction; but for a long time a real distinction was made between cases where there was and where there was not a real [BOTP].'

${ }^{266}$ See HT Riley (trans), The Annals of Roger of Hoveden, Vol 2 Pt 2 AD 1192 to 1201 (facsimile rep by Llanerch Publishers), pp 367-8.
} 
and summons of sheriffs, and at the cry of the country [crie de pays], to [sue] and arrest felons, when any need is, as well within the franchise as without and they that will not do so, and thereof be attainted, shall make a grevious fine to the king.[et ceux que ceo ne ferront, et de ceo soient attaintes, le roy prendra a eux grevement]. ${ }^{267}$

This chapter was not repealed until 1887. ${ }^{268}$ By then, hue and cry was long obsolete. ${ }^{269}$

In conclusion, from Anglo-Saxon times, there was an obligation on those who gave the oath of frankpledge to assist in the hue and cry. ${ }^{270}$ A failure to do so, resulted in a fine. By 1275, the punishment for failing to assist in the hue and cry was a 'grevious'fine.

\section{Arrest, Riots, Routs, Affrays Etc - Obligation To Assist}

As Pollock and Maitland note, the early law on arrest is obscure - even in early medieval times. ${ }^{271}$ Even more so then, in Anglo-Saxon times.

- However, even in Anglo-Saxon times, since the shire reeve (sheriff) and his underlings could not be everywhere, there must have been an individual at the village and town level who was primarily responsible for apprehending felons and either bringing them before the sheriff or executing summary justice;

- One would suggest this person was the headborough (borseholder). That is, the person responsible for the others in each tithing or hundred. Further, it is asserted this person was the forerunner of the petty and high constables. ${ }^{272}$ Thus, it seems likely that the headborough was the one who - in Anglo-Saxon times - instigated the hue and cry, the one who led the posse and the one who was the leader in the arrest (detention) of the suspected malefactor. Also, the one who reported to the sheriff those who had failed to join in the hue and cry or the posse.

Thus, when the constable appeared c. 1285 (or 1242 or, indeed, before that, see 4(c)), he gradually became the primary one to undertake such tasks - including the arrest of the malefactor. Progressing, then, from Anglo-Saxon times to those of early medieval England, one may note the statement of Bellamy:

Originally...the tithing and later the township had been responsible for the arrest of men who had committed homicide. ${ }^{273}$ At this time arrest was very closely connected with the hue and cry and was a prime duty of the constables of the vill, who were expected to lead the pursuit...The power to arrest ...suspects was carefully limited. Constables, bailiffs, and mayors in towns must be able to do it if they were to prevent breaches of the peace, but their action had to be based on their own knowledge of the misdeed. ${ }^{274}$

Because leading the hue and cry was the prime duty of the constable - and there was an obligation on able bodied

\footnotetext{
${ }^{267} 3$ Edw 1 c 9 (rep 1887). See also the statute, Of the Office of Coroner (De Officio Coronator) 4 Edw 1 (1276, rep 1887). It provided that: 'huy shall be levied for all [murders, burglaries and for men slain, or in peril to be slain] as otherwise is used in England; and all shall follow the huy and [cry][as near as can be] and he that does not, and is convict thereupon, shall be attached to be before the justice [of the gaol etc]' (spelling modernized). See also Hale, n 19, vol 2, p 87.

${ }^{268}$ Sheriffs 1887, s 39 and Coroners 1887, s 45.

${ }^{269}$ When hue and cry and cry became obsolete is unclear. However, this seems to have occurred by the $18^{\text {th }}$ century, see n 179.

${ }^{270}$ As to the age of the men, that for frankpledge was 12. However, the Proclamation of 1195 refers to males of 15 and it seems that the posse comitatus (power of the county) was usually 15 . As noted in the text to $\mathrm{n} 261$, although the hue and cry was primarily directed against felons, and later text writers refer to this, it does seem that it also covered lesser crimes as well as the discovery of death bodies in public places (since they gave rise to the suspicion of felony). Walker, $\mathrm{n} 67$ (posse comitatus)(the force of the county) 'In early English law, the force of able-bodied citizens of the county summoned and commanded by the sheriff to assist in maintaining public order, to pursue felons, or to participate in the military defence of the county. Attendance was enforced by the penalty of culvertage or turntail, which implied forfeiture of property and perpetual servitude. As the sheriff's authority declined, the posse became a purely civil body and, in time, the authority to call out such assistance was entrusted to justices and magistrates.'

${ }^{271}$ Bellamy, $\mathrm{n} 69$, pp 102-3. 'The powers of arrest possessed by the ordinary citizen were...ill-defined. Even FW Maitland could make little of them.' He refers to P \& M, n 43, vol 2, pp 582-4. Ibid, p 582 'The law of arrest is rough and rude; it is as yet unpolished by the friction of nice cases.'

272 See n 4(d).

273 See also Pugh, n 37, p 193 'Arrest, leading to imprisonment, was also effected by groups of villagers, often, no doubt, led or accompanied by a hundred officer, tithingman, or township constable. They had observed or suspected the occurrence of crimes, arrested the culprit on the spot, and either placed him in a nearby-house or lock-up or carried him across country to a gaol or castle. These are thirteenth-century instances.'

${ }^{274}$ Bellamy, n 69, pp 102-3. He continues 'The justices of the peace only received the power in 1361 and for a period of eighteen months. In March 1364 they were given instead the power to take sureties for good behaviour from those who threatened bodily harm or arson. For the arrest of notorious suspects by the justices a special commission was usually necessary.'
} 
men to participate in the latter and to pay a fine if they did not - then it would seem inevitable that, in law, refusing to participate in the hue and cry became refusing to assist the person conducting the same, the constable.

- The difficulty, is to pin-point when this actually occurred. ${ }^{275}$ That is, when the courts posited a separate offence of refusing to assist the constable, as opposed to fining able-bodied subjects for not participating in the hue and cry;

- One would suggest that this occurred when the king's peace expanded and subjects participated not just in catching felons, but in preventing other breaches of the peace.

In this latter respect, legislation made it an obligation for male subjects not otherwise exempt to participate in the posse in order to quell riots, unlawful assemblies and routs - which obligation was extended (in 1488) to assisting the constable to suppress affrays. As to this:

\section{(a) Riots, Unlawful Assemblies \& Routs}

In 1393, 1411 and 1414 legislation imposed an obligation on subjects to assist sheriffs and 'other ministers' (which expression came to include constables) in suppressing riots and major disorders. Thus,

- Act of 1393. Chapter 8 provided that: 'none shall make such assemblies, riot, or rumour against the peace in no wise; and if any such assembly be begun as soon as the sheriffs and other the king's ministers may thereof have knowledge, they will with the strength of the county [ie. the posse] and country, where such case shall happen shall set disturbance against such malice with all their power, and shall take such offenders, and them put in prison, till due execution of the law be of them made; and that all lords and other liege people of the realm, shall be attending with all their strength and power to the sheriffs and ministers aforesaid;' 276

- $\quad$ Act of 1411. Chapter 7 section 8 provided that: 'if any riot, assembly, or rout of people against the law be made in [parts] of the realm, that the justices of peace, three or two of them at least, and the sheriff or under-sheriff of the county where such riot, assembly, or rout shall be made hereafter, shall come with the power of the county [ie. the posse] if need be, to arrest them, and shall arrest them; ${ }^{277}$

- $\quad$ Act of 1414. Chapter 8 provided that: 'And that the king's liege people, being sufficient to travel in the county where such routs, assemblies, or riots be, shall be assistant to the justices, commissioners, sheriff or under sheriff of the same county, when they shall be reasonably warned, to ride with the said justices, commissioners, and sheriff, or under sheriff, in aid to resist such riots, routs, and assemblies, upon pain of imprisonment, and to make fine and ransom to the king., 278

Thus, subjects were obliged to help JP's and sheriffs stop riots etc. by joining the posse ${ }^{279}$ and, in time, constables came to become one of these 'other ministers', as well as take the place of the sheriff and his deputies.

\section{(b) Affrays}

The obligation on subjects to assist was further extended by caselaw in 1488 to the offence of affray. Affray comprised the offence of men fighting in a public place, to the fear of other subjects. Coke surmised that the word

\footnotetext{
${ }^{275}$ Cf. P \& M, n 43, p 582 'The constables who are becoming apparent at the end of our period [ie prior to the reign of Edward I [1272-1307] are primarily military officers, though it is their duty to head the hue and cry'. They cite Stubb's writ of 1242 (see n 77).

${ }^{276} 17$ Ric 2 c 8 (1393, rep 1967). Also called the Riots and Tumult Suppression Act 1393. Fitzherbert, n 14 (1538 ed)( Of the Office of Constables) cited this Act stating 'Sheriffs and other the king's ministers may take the power of the county [ie. the posse] to repress assemblies and riots, in outrageous number and to commit them to prison. It seems by these words (the king's ministers) the constables of towns have power to do so by this act as well as the sheriffs.' See also Allen, $\mathrm{n} 85, \mathrm{p} 49$.

27713 Hen IV c 7 s 1 (rep 1948). Also called the Riot Act 1411. See also Russell (in 1819), n 158, vol 1, p 385.

${ }^{278} 2$ Hen V st 1 c 8 (rep 1948). Also called the riot Act 1414. Fitzherbert, n 14 (1538 ed)(Of the Office of Constables) cited this Act stating 'Constables and all the king's liege people that are able to travel within the county must be assisting and aiding to the justices of peace and the sheriffs to repress great riots and unlawful assemblies, upon pain of imprisonment, and to make fine and ransom.' (spelling modernized). The word 'travel' appears to be a mis-reference to 'work' (ie. able bodied men), see $R v$ Pinney 5 C \& P 262 (172 ER 926), p 260 (note).

${ }^{279}$ Russell, (1819), n 158, vol 1, p 130 stated that it was a 'high offence to refuse to assist the king for the good of the public... in wars by personal service for defence of the realm against rebellion or invasion: under which class may be ranked the neglecting to join the posse comitatus, or power of the country, being thereunto required by the sheriff or justices, according to the statute 2 Hen V c 8 [ie. the Act of 1414] which is a duty incumbent on all that are fifteen years of age under the degree of nobility, and able to travel [work].' See also Blackstone, n 20 , vol 4, p 122 and Lambard, n 13, p 315.
} 
derived from the French 'affrayer'. ${ }^{280}$ He stated it was an offence in a person to fail to assist a constable who sought to stop an affray:

if the sheriff, justice of peace, constable, or other conservator of the peace do not part the affrayers for the preservation of the king's peace and apprehend them, being within his view, or do not his uttermost endeavour to part and apprehend them, they may be fined and imprisoned for their neglect thereof, for they may command others to assist them, and therefore the rule holds in them, idem est facere, et nolle prohibere cum possis: et qui non prohibit, cum prohibere possit, in culpa est. [to do something and being unwilling to stop something when one can, is the same: [thus] he who does not prevent [an offence] when he is able to do so, is culpable] And if any be commanded to assist them therein, and refuse or neglect the same, it is a contempt in them to be punished by a fine or imprisonment. ${ }^{281}$ (spelling modernised)

As authority for this, Coke cited Bedingfield's Case (1488) in which the court held that a constable could require subjects to assist in stopping an affray or such like. ${ }^{282}$

In conclusion, subjects had an obligation to participate in the hue and cry. By 1414, they also had a statutory obligation to help sheriffs and other ministers (which later included constables) to put down riots, routs and unlawful assemblies. And, in 1488, the courts imposed on them an obligation to assist a constable to stop an affray, the punishment being a fine or imprisonment if they failed to assist.

\section{Legal Writers: 1538 - 1599}

In the $16^{\text {th }}$ century, the first legal texts were written by Fitzherbert and Lambard with respect to JP's and constables as well as their respective duties. In both cases, these writers noted there was an obligation on subjects to assist constables in certain designated instances - both statutory and at common law. Also, by the end of the $16^{\text {th }}$ century, Lambard made a general statement on the obligation of subjects to assist a constable in the event of a BOTP. As to this:

\section{(a) Fitzherbert}

Fitzherbert, in his Newe Boke of Justices of the Peas (1538) - noting that constables were conservators of the peace pursuant to the common law ${ }^{283}$ and that they were such prior to legislation by which JP's were ordained 284 - also noted an obligation on townspeople to assist the town constable in catching felons:

if felons, or murderers be in the town, and the constable has knowledge thereof: it is his office and duty to assemble people for to take them. And if one take a felon in the town, and bring him to the constable to be conveyed to the gaol, the constable's office is to carry him thither and to cause other of the town to aid and assist him in so doing. ${ }^{285}$ (italics supplied)

Fitzherbert did not cite authority for this proposition. However, it is, effectively, a re-statement of the position as

\footnotetext{
${ }^{280}$ Coke, $\mathrm{n} 17, \mathrm{vol}$ 3, p 157 'An affray is a public offence to the terror of the king's subjects, and is an English word, and so called, because it affrights and makes men afraid, and is inquirable in a leet as a common nuisance...' (spelling modernized). Lambard, n 13, p 134 'Affray is derived of the French effrayer which signifieth to terrify, or bring fear: and is the more heinous trespass [than assault].' Russell, $n$ 158, vol 1, $p$ 388 'Affrays are the fighting of two or more persons in some public place, to the terror of his majesty's subjects.'

${ }^{281} \mathrm{Ibid}$, pp 157-8. The latin is rather obscure. However, it seems clear that Coke was effectively saying that 'to fail to prevent a crime when one able to, is as culpable as to commit a crime'. It may be noted that it was, from an early time, part of the constable's oath to arrest all those involved in riot and affray. See HT Riley (ed), Munimenta Gildhallae Londoniensis, Liber Albus (Longmans, 1859), vol 1, p 312.

${ }^{282}$ See 3 Hen 7 pl 4 fo 10b, Seipp Index, n 97, no 1488.035 (indictment of unlawful assembly). Seipp reports 'They (justices) also said that the sheriff's bailiff could levy the king's people [ie. subjects] to execute an order to arrest (take the body of) any person, and that the constable of a vill (could do this) upon a fight (affray) and suchlike.' Sir Edmund Bedyngfeld (1443-96) was sheriff of Norfolk and Suffolk, 1486-7. See also ODNB, $n 263$ (Bedingfield family).

${ }^{283}$ Fitzherbert, n 14 (1538 ed)(Of the Office of Constables) 'As for asmuch as the office of a constable was an office at the common law, and was ordained for the conservation of the king's peace to be had and kept in every town among the king's subjects there dwelling...' (spelling modernized).

${ }^{284}$ Ibid. 'Also the constables of every town were and be keepers of the peace by the common law, likewise the high constables of hundreds, wapentakes, lathes or tythings were and be conservators of the peace by the common law within the towns or hundreds and within their limits. And before the making of the statutes whereby justices of the peace are ordained, the king by his commission made conservators of the peace in those counties and places where him [he] thought best to keep his peace. And the authority which conservators of the peace had by the common law, is the same authority that a constable of a town or wapentake has at this day....' (spelling modernised). With reference to statute governing JP's, it unclear whether Fitzherbert was referring to the Justice of the Peace Act 1361 or to earlier legislation, such as Acts of 1328 (1 Edw 3 c 16, keepers of the peace), 1330 (4 Edw 3 c 2, keepers of the peace) and 1344 (18 Edw 3 c 2, keepers of the peace). One would suggest he was referring to the position pre-1328. For the meaning of wapentake, see Coke, n 17, vol 2, p 99.

285 Ibid.
} 
regards the duty of a subject with respect to hue and cry, which applied against felons in particular (see 14).

\section{(b) Lambard}

For his part, Lambard cited various instances in which subjects were called on to assist constables, viz.

- $\quad$ Affray. In respect of affray, in his Eirenarcha, (1581), Lambard, - citing Bedingfield's Case (1488) stated (see 15(b)): 'the justice [of the peace] or constable may (if need be) command assistance of the Queen's people for the pacifying of an affray',286

- Nightwalkers. In his text on the Duties of Constables ((I cite the 1599 edition), after defining the queen's peace, ${ }^{287}$ Lambard referred to the right of a constable to call for assistance in the case of suspected bawdry. He stated: 'But now, for the better preventing that nothing be done against the peace, any of these officers aforesaid may take (or arrest) suspected persons which walk in the night, and sleep in the day or which do haunt any house, where is suspicion of bawdry: and they may carry them before a justice of the peace, to find sureties of their good behaviour. And if any such officer be not of sufficient strength to do that alone then he may take meet aid of his neighbours thereto: and they, in such cases, be compellable to help and assist him'; ${ }^{288}$

- Riots. Referring to the Act of 1393 in respect of riots (see 14), Lambard stated: 'if any great assembly, or rumour of people be made in manner of insurrection, then the sheriffs, constables and these said other ministers, having knowledge thereof, ought to go with the strength of the county and to set themselves against it, and ought also to take and imprison such offenders.' 289

- Incontinency. Lambard stated 'And I like well of their opinion, which do hold, that if information be given to any such officer, that a man and a woman be in adultery, or fornication together then the officer may take companion with him, and that if he find them so, he may carry them to prison.' 290 Lambard referred to Gylys v Watterkyn (1486). In this case, pursuant to an information - and acting in accordance with a supposed London custom - a constable took a parish beadle and others to the house of man committing adultery. Arresting him, the constable imprisoned him in the London counter (a prison). A subsequent action by the man against the constable for false imprisonment did not proceed to judgment. This, doubtless was, in part, because there was uncertainty among the judges whether the London custom could be upheld as a reasonable one. ${ }^{291}$

Lambard also made a general statement as to the duty to assist a constable:

\footnotetext{
${ }^{286}$ Lambard, n 13, pp 143-4. See also Lambard, n 71, p 15, 'may also call others to assist him' (see also 1640 ed, p 14 where repeated).

${ }^{287}$ Lambard, $\mathrm{n} 71$, pp 11-2 'The conservation (or maintenance) of the peace, stands in three things, that is to say: first, in foreseeing that nothing be done, that tends either directly, or by means, to the [BOTP]: secondly, in quieting or pacifying those that are occupied in the [BOTP]: and thirdly, in punishing such as have already broken the peace. ...by the [BOTP], is understood, not only that fighting, which we commonly call the [BOTP], but also that every murder, rape, manslaughter, and felony whatsoever, and every affraying (or putting in fear) of the Queen's people, whether it be by unlawful wearing of armour, or by assembly of people to do any unlawful act, are taken to be disturbances of the peace...' (see also 1640 ed, pp 10-1). Cf. in his Eirenarcha (1581), n 13, p 135 'Menacings then, affrays, assaults, injurious and violent handlings, and mistreatings of the person, batteries malicious strikings etc be breaches of the peace...'

${ }^{288}$ Ibid. (see also 1640 ed, p 11). Authority for this may be found in the case of 13 Hen 7 pl 10 fo 10b (1497), Seipp Index, n 97, no 1497.021. Seipp records 'all the justices. It is permitted (congeable) for every constable to take the suspected persons, who go about in the night (vont en la nuit, night walkers), and sleep in the day, or who keep suspicious company, and also if there be no power to arrest them, he (constable) can have aid of his neighbours (voisins) and they (neighbours) are compellable to (do) this by law'. It may be noted that, to prevent felonies, the nightwatchmen could raise hue and cry against nightwalkers who fled, see Statute of Winton 13 Edw 1 st 2 c 4 (1285, rep) 'If any will not obey the arrest of the town, where night-walkers pass, they shall levy hue and cry upon them, and such as keep the town (viz. the bailiff or constable) shall follow with hue and cry with all the town and the towns near; and so hue and cry shall be made from town to town, until they are taken and delivered to the sheriff; and for arrestments of such strangers none shall be punished.' See also Lambard, $\mathrm{n} 71$, pp 12-3 and Hale, $\mathrm{n}$ 19, vol 2, ch 4.

${ }^{289}$ Ibid, p 14.

${ }^{290}$ Ibid, p 18. Repeated in 1640 edition, see $\mathrm{n} 71$ (1640 ed), p 17

${ }^{291}$ See 1 Hen $7 \mathrm{pl} 3$ fo 6a-7b, Seipp Index, n 97, no 1486.003. This case comprised an trepass for assault, battery and imprisonment where the London custom was pleaded as a justification against the claim of false imprisonment. See also JH Baker \& SFC Milsom, Sources of English Legal History (Butterworths, 1986), p 310. It cited The Newe Littleton (c.1644)(Lord Littleton's Legal Digest) which stated 'And by a special custom in London if information be given unto any constable there that any within his jurisdiction is with any woman in adultery, he may call the beadle and others of the same parish and go unto the house, and if they find the man in adultery, to take and conduct him unto the compter and there leave him in prison until he shall pay so much or be there delivered by the due course of the law; and this is held to be a good custom...' For this London custom see also GS McBain, Liberties and Customs of the City of London - Are there any Left? (2013) International Law Research, vol 2, no 1, p 47 (adultery). See also, for frequent cases of chaplains being caught in London in adultery, HT Riley, Memorials of London and London Life...AD 1276-1419 (Longman, 1868), pp 566-7 (eg 1406, pillory for a chaplain caught in adultery with a tailor's wife by the bedel).
} 
If therefore a constable, or any other of the said officers, shall see any men going about to break the peace, as by using hot words: ... if they will not depart...then ... he may also call others to assist him. ${ }^{292}$

This wording is important since, one suspects, this was the first time anyone had asserted the proposition so widely, with reference to a BOTP. Prior to this, the obligation on a subject to assist was always stated with regard to specific instances. Further, since Lambard was treated as an important text in relation to constables - and since his text went through many editions - it is likely that his opinion on the matter (he cited no authority for his proposition) became the perceived wisdom and, thus, the law.

In conclusion, the texts of Fitzherbert and Lambard evidence the evolution of the offence of refusing to assist a constable by not participating in the hue and cry to other instances - such as a statutory obligation re riots etc and common law ones re affray, nightwalkers and (possibly) adulterers. Further, it may be that Lambard is the source of the modern proposition in respect of a duty to assist vis-à-vis a BOTP, since the caselaw prior to Lambard does not suggest that the courts were prepared to go so far.

\section{Legal Writers: Dalton \& Coke}

Following on from Fitzherbert and Lambard, in the $17^{\text {th }}$ century, Dalton in his The Countrey Justice (I cite the 1619 edition) mentioned the obligation of subjects to provide assistance to a constable ${ }^{293}$ in the case of:

$$
\begin{aligned}
& \text { (a) affray; }{ }^{294} \\
& \text { (b) riots, routs and unlawful assemblies; }{ }^{295} \text { and } \\
& \text { (c) incontinency. }{ }^{296}
\end{aligned}
$$

However, Dalton also declared, in effect, that there was a general obligation on subjects to assist a constable to prevent a BOTP, stating:

Every of these conservators of the peace (by the ancient common law) are to employ their own valour, and may also command the meet help, aid and force of others, to arrest and pacify all such, who in their presence, and within their jurisdiction and limits, by word or deed, shall go about to break the peace. ${ }^{297}$

For his part, when Coke came to write his Institutes of the Laws of England, in four volumes, published between 1628-41, he did not say much about JP's and constables, preferring to leave this (as he noted) to Fitzherbert and Lambard. However, he did note that:

Divers and many acts of parliament have given the chief constable and petty constable more authority and

\footnotetext{
${ }^{292}$ Ibid, p 15.

${ }^{293}$ Dalton, $\mathrm{n} \mathrm{16, \textrm {p }} 2$ 'The high constables of hundreds, are conservators of the peace, within their several hundreds and limits. Every petty constable within the limits of their several towns be conservators of the peace by virtue of their office...It seemeth the name and office of a constable with us, is the same that the borsholder is in Kent, thirdborow in Warwickshire, and tithingman and borowhead is in other places.'

${ }^{294}$ Ibid, p 29 'If the affrayors will not depart, but shall draw weapon, or give any blow, the constable may command assistance of others for the pacifying of the affray, and may justify the hurting of them, if they make resistance' (spelling modernised). Also, p 315 'The constable (of a town) upon a felony committed, or upon any affray, or the like, may take the aid of his neighbours, or other persons being present, to apprehend the felons, or to cause the peace to be kept, and to carry the offenders before the justice etc.' Reference is made to Bedingfield's Case (1488) (see $\mathrm{n} 282$ ) and to the case in 1497 relating to nightwalkers (see $\mathrm{n} 288$ ).

${ }^{295}$ Ibid, p 101 'And they shall take the power of the county (if need be) $s c$ they shall have the aid of the knights, and other temporal persons under that degree, that be above the age of $\mathrm{xv}$ [15] years, and be able to travel: for all the $\mathrm{k}[\mathrm{ing}$ 's] subjects that are in the country where a riot etc shall be, being able to travel, must be aiding and asistant to the Iu of $\mathrm{P}$ [justice of peace] sheriff or undersheriff (or other commissioners) when they shall be reasonably warned, to ride or go with the said justices, etc sheriff etc in aid to resist such riots etc upon pain of imprisonment, and to make fine and ransom to the k[ing] which ransom shall be treble so much at the least as the fine, Dyer 232.' (spelling modernized). The reference to Dyer is to Sir Edward Norton's Case (1564) 2 Dyer 232a (73 ER 512). Also 'p 130 'And the power of the county ought to be aiding to the sheriff or under-sheriff, for the conveying of them to the gaol' (spelling modernized). Also, p 202. Also, p 313 'Where the Iust of $\mathrm{P}$ [justice of peace], sheriff, or other officer, is enabled to take the power of the county, it seems, they may command, and ought to have the aid and attendance of all knights, gentlemen, yeomen, husbandmen, labourers, tradesmen, servants, and apprentices, and of all such persons being above the age of 15 years, and that are able to travel. But women, ecclesiastical persons, and such as be decrepit or diseased of any continual infirmity, shall not be compelled to attend them.' (spelling modernized). Also, p 314.

${ }^{296}$ Dalton, n 16, p 309 (writing in 1629) 'A constable being informed of a lewd man and woman that are together in incontinency, may take with him so many of his neighbours as he will, to arrest the said man and woman to find sureties for their good behaviour'. Reference is made to Gylys v Watterkyn (1486) (see n 291) and to the case in 1497 relating to nightwalkers (see n 288). See also Hale, n 19, vol 2, p 89.

${ }^{297}$ Ibid. p 3. Dalton stated no authority for this. However, it may have been Lambard since he also referred to 'going about to break the peace.' Dalton also stated, p 7 'The breach of this peace seems to be any injurious force or violence moved against the person of another, his goods, lands, or other possessions, whether it be by threatening words, or by furious gesture or force of the body, or any other force used in terrorem populi'. (spelling modernized),
} 
power than originally they had... ${ }^{298}$

Coke's statement was accurate, in that it reflected the diminishing legal influence of the sheriff and his underlings (under-sheriffs, bailiffs etc). It also reflected the increasing authority given to the constable. Further, Coke, referring the hue and cry, in the context of the Statute of Westminster 1285, c 9 (see 13(c)), ${ }^{299}$ noted:

Men ought to be in these cases at the commandment of the sheriff, for he hath custodiam comitatus committed to him; and he that goes not at the commandment of the sheriff or constable at the cry of the country, that is, upon hue and cry, shall be greviously fined and imprisoned. ${ }^{300}$ (italics supplied)

The reference to the 'constable' in this context shows that, by this time - in the context of a failure to assist - he was included along with the sheriff. In respect of felony, Coke also observed:

If a murder be committed in the day time in a town not enclosed, and the murderer not apprehended, the township shall be amerced, but if inclosed, whether the murder be in the night, or day, the town shall be amerced. They that are present when any man is slain, and do not their best endeavour to apprehend the murderer, or manslayer shall be fined or imprisoned. ${ }^{301}$

As to bawdry, Coke considered this a matter for the ecclesiastical court and did not deal with it further. ${ }^{302}$ Finally, Coke also noted that the posse could be used by a sheriff in the case of a writ. He stated:

If any man, how great so ever, might have resisted the sheriff in the executing of the king's writs...[this] is against the common law... [thus] of necessity, if need be, for the due execution of the king's writs, the sheriff may by the common law take posse comitatus to suppress such unlawful force, and resistance. ${ }^{303}$

In conclusion, Dalton whose popular legal text on justices of the peace, The Country Justice, was published from 1618 -1746, like his predecessor Lambard - as well as citing specific instances in which subjects were obliged by statute and the common law to assist a constable - stated a general proposition that a constable could command the assistance of others to pacify those who 'shall go about to break the peace.' One suspects Lambard took this from Dalton.

\section{Legal Writers: Hawkins, Burn, Blackstone \& Ritson}

When the work of Dalton was declining somewhat, another major text on criminal law commenced its rise. This was Hawkins, A Treatise on Pleas of the Crown, first published in 1716, which was not to have its last edition until 1824. Hawkins summarised the circumstances in which a person was obliged to assist a constable, without placing them under one specific heading. Thus:

- $\quad$ Felonies. Hawkins stated: 'it seems clear, that all persons whatsoever who are present when a felony is committed, or a dangerous wound given, are bound to apprehend the offender, on pain of being fined or imprisoned for their neglect, unless they were under age at the time; ${ }^{304}$

\footnotetext{
${ }^{298}$ Coke, n 17, vol 4, p 267.

${ }^{299}$ Coke also referred to 27 Eliz c 13 (An Act for the following of Hue and Cry)(rep). Among other things it specified, s 1, that the inhabitants of hundreds, where fresh suit was not made of hue and cry, should answer for half the damages. Also, s 8 , that hue and cry should be by horsemen and on foot. See also Winterstoke Hundred's Case (1579) 3 Dyer 37a (73 ER 829).

${ }^{300}$ Coke, n 17, vol 2, p 172. See also Hale, n 19, vol 1, p 588 (citing Coke) and vol 2, ch 12. Also, vol 1, p 588 'If the constable in pursuit of a felon require the aid of JS he is bound by law to assist him, and is finable for his neglect.' He cited the case in $\mathrm{n} 288$.

${ }^{301} \mathrm{Ibid}, \mathrm{vol} 3, \mathrm{p} 53$. Also, p 139 'If any be present when a man is slain, and omit to apprehend the slayer, it is a misprision, and shall be punished by a fine or imprisonment.' See also Hale (writing in the 1640's), n 19, vol 1, pp 448-9 'If any private person be present when a murder or manslaughter is committed, and does not his best endeavour to apprehend the malefactor, he shall be fined and imprisoned.' (spelling modernized).

${ }^{302}$ Ibid, p 205 'See the case of 1 Hen 7 the custom of London for entering into a house, and arresting of an advowtrer [adulterer],and carrying her to prison...but now these offences belong to the ecclesiastical court' (spelling modernized). For this case, see $\mathrm{n} 291$.

${ }^{303}$ Ibid, vol 2, p 193. He cited the Statute of Westminster 1285, c 39 in support. See also Pulton (writing in 1609), n 15, p 13 'In an action for false imprisonment against two, one of them pleaded that he had a precept to arrest the plaintiff which he did accordingly, and the other defendant pleaded that he came in company with the other to aid and assist him to arrest the plaintiff. And this was allowed a good justification in them both: for any stranger may assist the sheriff, his bailiffs or any other that has authority to execute the king's writ or process, and he that will not assist him being required shall pay a fine to the king: and the sheriff may take as many persons as he will to aid him to execute the king's writs, for it is in furtherance of justice and no [BOTP].' See also Hale, n 19, vol 1, p 577 'the sheriff or his bailiff may require any persons present to assist him in execution of the [king's] writ, and he that refuseth to assist him, is indictable and punishable by fine and imprisonment.' As to a JP's warrant, $\mathrm{p} 581$ 'If to a constable, tithing-man etc... he may call any persons to assist him, and they are bound to assist him, and are indictable if they neglect or refuse to assist.'

${ }^{304}$ Hawkins, n 18, vol 2, p 74. He continued 'And for this cause, by the common law if any homicide be committed, or dangerous wound given, whether with or without malice, or even by misadventure or self defence, in any town or in the lanes or fields thereof, in the day time, and the offender escape, the town shall be amerced, and if out of a town, the hundred shall be amerced.'
} 
- Hue \& Cry. Hawkins stated: 'And as all private persons are bound to apprehend all those, who shall be guilty of any of the crimes abovementioned in their view; so also are they with the utmost diligence to pursue, and endeavour to take all those who shall be guilty thereof out of their view, upon a hue and cry levied against them; ${ }^{305}$

- Riots, Routs \& Unlawful Assemblies. Hawkins stated: 'It seems clear, that every sheriff and under-sheriff, and also every other peace officer, as constables etc may do and ought to do all that in them lies towards the suppressing of a riot, and may command all other persons whatsoever to assist them therein;' 306

- $\quad$ Affray. Hawkins stated: 'Also every private person is bound to assist an officer demanding his help for the taking of a felon, or the suppressing an affray, or apprehending the affrayers, etc. ${ }^{307}$ Also, 'As to...how far an affray must be suppressed by a constable; it seems agreed, that a constable is not only impower'd, as all private persons are, to part an affray which happens in his presence, but is also bound at his peril to use his best endeavours to this purpose, and not only to do his utmost himself, but also to demand the assistance of others, which if they refuse to give him, they are punishable with fine and imprisonment.' 308

These above statements of Hawkins were scarcely altered in the last edition of his work in 1824. Thus, the law from 1716-1824 (a period of 108 years) was unchanged in this respect - albeit hue and cry, by 1824, must have been rare. ${ }^{309}$ As to other legal writers in this period:

- Burn, in the first edition of his Justice of the Peace and Parish Officer in 1755, said something on the constable and his antiquity. ${ }^{310}$ However, he said little on the constable's power as a conservator of the peace or the duty of a subject to assist him; ${ }^{311}$

- Blackstone, writing in 1765 , also said little about the office of constables, preferring to refer to Lambard and Burn as the principal authorities on them. ${ }^{312}$ However, in respect of arrest by a constable without a warrant, he stated: 'Any private person (and a fortiori a peace officer) that is present when any felony is committed, is bound by law to arrest the felon; on pain of fine or imprisonment, if he escapes through the negligence of the standers by. ${ }^{313}$ He also mentioned hue and cry. ${ }^{314}$

Finally, Ritson, in a useful work on constables in 1791, noted that the constable was ordained to repress felons as well to keep the peace, of which he was a conservator by the common law. ${ }^{315}$ As well as referring to the obligation of the constable in respect of: (a) hue and cry; ${ }^{316}$ (b) felony; ${ }^{317}$ and (c) affray, ${ }^{318}$ Ritson made an

\footnotetext{
${ }^{305}$ Ibid, p 75. As to what hue and cry was, Hawkins stated 'Hue and cry is the pursuit of an offender from town to town till he be taken, which all who are present when a felony is committed, or a dangerous wound given, are by the common law as well as by statute, bound to raise against the offenders who escape, on pain of fine and imprisonment: also it seems certain, that a man may lawfully raise it against one who sets upon him in the highway to rob him...but if a man take upon him to levy a hue and cry without sufficient cause, he shall be punished as a disturber of the peace.' Also, as to how it was raised 'In order rightly to raise a hue and cry, you ought to go to the constable of the next town, and declare the fact, and describe the offender and the way he is gone: whereupon the constable ought immediately, whether it be night or day, to raise his own town, and make a search for the offender.'

${ }^{306}$ Hawkins, n 18, vol 1, p 158. He referred to the Act of 1411 (see n 277) and stated, p 161 'That all persons whatsoever, and even noblemen, and all others of what condition or degree soever they may be, except women, clergyman, persons decrepit, and infants under the age of fifteen years, are bound under pain of fine and imprisonment upon reasonable warning to attend the justices and sheriffs in the execution of the said statute, and not only to arrest the rioters but also to conduct them to prison.'

307 Ibid.

${ }^{308}$ Ibid, vol 1, p 137. For the 1824 (last) edition, see vol 1, p 490. In support of this proposition, Hawkins referred to Coke, Hale, Lambard, Dalton as well as Bedingfield's Case (1488) (see n 282).

${ }^{309}$ See n 179 .

${ }^{310}$ Burn, n 14, vol 1 (Constable). See also, for example $23^{\text {rd }}$ ed (1820), see n 24.

${ }^{311}$ Ibid, p 222. Generally, Burn cites Coke, Dalton and Hawkins on constables.

${ }^{312}$ Blackstone, n 20, vol 1, pp 343-5.

${ }^{313}$ Ibid, vol 4, p 289. Blackstone cited Hawkins (see n 18), vol 2, p 74.

${ }^{314}$ Ibid, pp 290 (on which he said little). On affray, pp 145-6, Blackstone did not mention any law on assisting a police constable.

${ }^{315}$ Ritson, n 71, p 1.

316 Ibid, p 11.

${ }^{317}$ Ibid, p 14, 'If one take a felon in the vill, and carry him to the constable, it is his duty to convey him to the jail, and to cause others of the vill to assist him.' Also, p 15 'If felons or murders be in the vill, and the constable have knowledge thereof, it is his office and duty to assemble people and take them...'. See also $\mathrm{p} 18$.

${ }^{318}$ Ibid, p 14 'The office of constable is to take such as make affray, and imprison them till they are bound to the peace.'
} 
expansive statement about the obligation of subjects to assist in the case of arrest:

He may take aid of his neighbours to arrest another, and they are compelled to assist him by law; and, upon affray and such like, he may raise the people of the realm to cause the peace to be observed. ${ }^{319} \ldots$ He may command his neighbours to assist him in the execution of any authority or duty vested in him by the common law; but not by particular statute, unless in special cases. ${ }^{320}$

That said, Ritson also cited an important case $-R v$ Wildbore (1694). ${ }^{321}$ It held that a constable could not require a person to assist him execute the warrant of two justices to search for nets and other engines used to catch rabbits. Thus, the power of the constable was not wholly open-ended.

In conclusion, as well as statutory obligations to assist in respect of riots etc, there were common law obligations imposed on a subject to assist in the hue and cry and the posse, as well as cases of affray and the enforcement of a writ or warrant. Like Lambard and Dalton before him, Ritson also referred to a more general obligation to assist a police constable 'in the execution of any authority or duty vested in him by the common law.'

\section{Position Prior to the Case of Brown (1841)}

Russell, whose major work on Crimes and Misdemeanours was first published in 1819, referred to an obligation to assist in respect of affrays ${ }^{322}$ and riots, ${ }^{323}$ but was dubious about the position in respect of nightwalkers. ${ }^{324}$ Further, he made no general remarks about the nature of the offence. It may be useful, therefore, to summarise the extent of the offence of refusing to assist prior to considering $R v$ Brown (1841): ${ }^{325}$

- Constables. These officers likely arose from the common law and comprised the successors to the Anglo-Saxon headborough (boroesholder, tithingman) whom they gradually replaced. They likely were first mentioned in legislation in 1275 (and, perhaps, in a writ in 1242). They comprised high and petty constables (high constables were abolished by the High Constables Act 1869);

- Frankpledge, Huy and Cry, Posse. These were vital components of a police system based on small communities where mutual obligation and protection was the key. By the $14^{\text {th }}$ century, however, frankpledge had lost most of its purpose ${ }^{326}$ and it (and the court leet) began to decline - the power of the king's justice and courts expanding. The hue and cry also began to decline about that time, especially after JP's started to issue summonses and warrants for the apprehension of suspects. ${ }^{327}$ The posse would still have been used to deal with large riots and unlawful assemblies. However, after 1688, Britain had a standing army and, after 1714, the Riot Act applied. This, and the presence of

\footnotetext{
319 Ibid, p 10.

${ }^{320}$ Ibid, p 13.

${ }^{321}$ Comb 309 (90 ER 496). It stated 'Indictment for not assisting the constable (upon request) to execute the warrant of two justices, for searching for nets and other engines to take conies etc. was quashed, for the constable hath no power to require whom he will to attend him on such occasions.'

${ }^{322}$ Russell, n 158, vol 1, p 392 'a constable is not only impowered, as all private persons are, to part an affray which happens in his presence; but is also bound, at his peril, to use his best endeavours for this purpose; and not only to do his utmost himself; but also to demand the assistance of others, which, if they refuse to give him, they are punishable with fine and imprisonment.' He also noted, p 393, that 'it seems to be the better opinion, that a constable has no power to arrest a man for an affray done out of his own view, without a warrant from a justice of peace, unless a felony be done, or likely to be done ...'

${ }^{323}$ Ibid, vol 1, p 384 'By the common law the sheriff, under sheriff, constable, or any other peace officer, may, and ought to do, all that in them lies towards the suppressing of a riot, and may command all other persons to assist them....' Russell also referred to the Act of 1411 (see $\mathrm{n} 277$ ) and stated 'In the interpretation of this statute it has been holden, that all persons, noblemen and others, except women, clergymen, persons decrepit, and infants under fifteen are bound to attend the justices in suppressing a riot, upon pain of fine and imprisonment...'. He referred to Blackstone, n 20, vol 4, pp 146-7 and to Hale, n 19, vol 1, p 495.

${ }^{324} \mathrm{Ibid}$, vol 1, p 726 (he was dubious whether constables had the power to arrest fleeing nightwalkers, if innocent and there were no reasonable grounds of suspicion to mislead the officer).

${ }^{325}$ It may be noted that the main writers (and those constantly cited) tended to be: (a) Fitzherbert (his The New Boke of Justices of the Peas, (enlarged by Crompton) was published from 1538-1617); (b) Lambard (his text on justices of the peace, Eirenarcha was published 1581- 1619 and his text on the Duties of Constables etc. (see n 71) from 1582-1640); (c) Dalton (his The Countrey Justice was published from 1618-1746); and (d) Hawkins (his $A$ Treatise on the Pleas of the Crown, was published from 1716-1824).

${ }^{326}$ Allen, n 85, p 79 'The frankpledge system lost most of its character and purpose during the fourteenth century....By Blackstone's time tithing is simply synonymous with town or vill.'

${ }^{327}$ Ibid, p 85 .
} 
professionalised police force after 1829 - as well as the ability to create special constables - rendered otiose the need to compulsorily require subjects to help; ${ }^{328}$

- Obligation to Assist - Common Law. This likely originated in the Anglo-Saxon hue and cry in which all male subjects over 12 who had given frankpledge were required to participate. This continued in Anglo-Norman times, with the posse referring to male subjects over 15 . The obligation was to assist the shire reeve (sheriff). In time, his role was taken over by the constable. Thus, in effect, the obligation was to assist the constable in the hue and cry and the posse. The hue and cry was directed, in the main, against outlaws and felons although it was extended too other crimes (such as forgery). In 1488 (Bedingfield's Case), the court held there was an obligation to assist a constable to prevent an affray. With regard Gylys $v$ Watterkyn (1486), it may be that subjects had also had an obligation to assist a constable (at least in London) to suppress bawdry (although Coke, and it seems others, later asserted that this was a matter for the ecclesiastical courts). It also seems that subjects had an obligation (via the posse) to assist a sheriff in executing the king's writ (at least, Coke asserted so) and JP's in executing their warrants. However, there was no general obligation at common law prior to $R v$ Brown (see below) to assist a constable - the case of Wildbore (1694), effectively, making this clear; ${ }^{329}$

- Obligation to Assist - Legislation. In 1393, 1411 and 1414, legislation imposed an obligation on subjects to assist the sheriff and 'other ministers' in order to quell riots, unlawful assemblies and routs. In time, the constable also assumed this function;

- Obligation to Assist - Legal Writers. Writers like Lambard, Dalton and Ritson referred to a more general obligation to assist a constable, when requested, in the case of a BOTP or an arrest. However, no court case appears to have gone so far.

In conclusion, the offence of refusing to assist a constable evolved from being one restricted to specific occasions (in legislation and at common law) to a more general duty - at least, as opined by some legal writers. However, prior to Brown (1841) it was unclear whether these specific occasions had become a more general obligation of refusing to assist a constable to prevent a BOTP. This is likely why Alderson B 'skirted'over the issue in Brown (1841) (see below).

\section{Cases of Brown (1841) \& Sherlock (1866)}

\section{(a) $\underline{\text { Brown (1841) }}$}

Archbold (2014) summarised this case as follows:

Refusing to aid and assist a constable in the execution of his duty, in order to preserve the peace, is an indictable misdemeanor at common law. In order to support such an indictment, it must be proved that the constable saw a BOTP committed; that there was a reasonable necessity for calling upon the defendant for his assistance; and that when duly called on to do so, the defendant, without any physical impossibility or lawful excuse, refused to do so. And it is no defence that the single aid of the defendant could have been of no avail: $R \vee$ Brown (1841)... 330

In this case, a single police constable was faced with a prize fight involving some 400 spectators. ${ }^{331}$ Among others, he approached the defendant who was seated on a box carriage drawn by four horses. He told him: 'I charge you in the Queen's name to aid and assist in quelling this riot'. The defendant refused on the false basis that he had to care for the horses, whereas that was the responsibility of others. The defendant was found guilty of refusing to assist the constable. He was fined 40s and ordered to find sureties for his good behaviour. Alderson B stated:

It is no unimportant matter that the Queen's subjects should assist the officer of the law, when duly required to do so, in preserving the public peace...It is necessary that you [the jury] should be satisfied of three particulars...

\footnotetext{
${ }^{328}$ In particular, 'special constables' comprised the posse in a more professional form. It also accorded protection to subjects who were prepared to assist, with their being treated as constables. The preparedness of many subjects to voluntarily assist as special constables rendered obsolete the element of legal compulsion contained in the hue and cry and the posse.

329 See $n 321$.

${ }^{330}$ Archbold, $n$ 4, para 19-336. C \& Mar 314 (174 ER 522). See also 4 ST (NS) App A. In this case Alderson B summarised it 'The offence imputed to the defendant is this - that Herbert being a constable, and there being a [BOTP] actually committing under his own view, he called upon the defendant to assist him in putting an end to it, and that he without lawful excuse refused so to do.'

${ }^{331}$ Prize fights remained a considerable problem in Victorian England. For the legal position in 1877, see Paterson, n 164, vol 1, p 308. See also $R v$ Coney (1882) 8 QBD 534 (attendance at a prize fight, whether guilty of assault).
} 
first, that the constable actually saw a [BOTP] committed by two or more persons. It is clear that all prize fights are illegal, and that all persons engaging in them are punishable by law...Secondly, you may be satisfied that there was a reasonable necessity for the constable...calling upon other persons for their assistance and support; and in this case there is no doubt that the constable could not by his own unaided exertions have put an end to the combat. Lastly, the prosecutor must prove that the defendant was duly called upon to render his assistance, and that, without any physical impossibility or lawful excuse, he refused to give it.

Whether the aid of the defendant, if given, would have proved sufficient or useful is not the question or the criterion. Every man might make that excuse, and say that his individual aid would have done no good; but the defendant's refusal may have been and perhaps was the cause of that of many others. Every man is bound to set a good example to others by doing his duty in preserving the public peace. ${ }^{332}$ (wording divided for ease of reference)

The defendant being found guilty, a fine of 40 s was imposed. He was also required to find suerties for good behaviour. The same applied to three others charged with pleaded guilty. Did Alderson B create a new offence? The answer would appear to be ' $n o$ '. However, he certainly extrapolated an existing one and he cited no caselaw to support his doing so. As to that extrapolation, the following may be noted:

- Able-bodied Males. Frankpledge was required of male subjects over the age of 12 . The following were excluded or exempted from giving such an oath: (a) clerks; (b) knights and their eldest sons; (c) women; (d) vagrants; (e) persons in religion. ${ }^{333}$ The posse applied to male subjects over $15 .{ }^{334}$ Finally, for the purposes of the Acts of 1411 and 1414 re riots etc, the age for males was also 15. Excluded or exempt from the posse were: (a) women; (b) persons in religion; (c) those 'decrepit or diseased of any continual informity'. ${ }^{335}$ For his part, Alderson $\mathrm{B}$ in Brown referred to males 'without any physical impossibility or lawful excuse'. These words would seem to cover the same as the posse requirement;

- $\quad$ BOTP. The Acts of 1393, 1411, 1414 related to posses to suppress riots, unlawful assemblies and routs. These would be out of the 'view' (geographical jurisdiction) of the constable. However, it seems clear that the prevention of felonies, ${ }^{336}$ affrays and bawdry ${ }^{337}$ had to be in the constable's view as well as the service of warrants and writs. ${ }^{338}$ For his part, Alderson B in Brown required that the 'constable actually saw a [BOTP]committed by two or more persons;'

- Request/Command \& Reasonable Necessity. In the case of the statutory and common law offences, the constable could 'command' assistance. For his part, Alderson B limited this to a request (albeit a person to whom it was directed must accede to it). Also, Alderson B required that it must be a 'reasonable necessity for the constable' to call for assistance.

Given that frankpledge, hue and cry were obsolete by 1841 and that prior legal writers had referred to a BOTP, this re-statement of the law by Alderson B was not unreasonable. Further, Alderson B ameliorated the obligation imposed on a male subject somewhat - probably in order to accord with more modern times and the fact that constables would likely be able to call on the assistance of their colleagues more easily.

\section{(b) $\underline{\text { Sherlock (1866) }}$}

In this case, two men charged with felony were taken into custody by two constables and a peace officer. In seeking to escape, the two men assaulted the constables who called on Sherlock (it is unclear whether he was related to those detained). The indictment cited in the case declared that he did 'unlawfully, wilfully and knowingly refuse to aid and assist the constables in the execution of their duty, or to prevent an assault and [BOTP].' Archbold (2014) summarised this case as follows:

An indictment for refusing to assist a constable in the execution of his duty, and to prevent an assault

\footnotetext{
${ }^{332}$ At $\mathrm{p} 318$.

${ }^{333}$ See ns $86 \& 87$.

${ }^{334}$ See ns 266 (proclamation of 1195 ) \& 270.

${ }^{335}$ Seen 295 (Dalton) and 306 (Hawkins).

${ }^{336}$ See ns $300 \& 304$.

${ }^{337}$ See ns 294 \& 322 (affray) and $291 \& 296$ (bawdry).

${ }^{338}$ See n 303.
} 
made upon him by persons in his custody on a charge of an offence made with intent to resist their lawful apprehension, is sufficient without stating how the apprehension became lawful; and it is sufficient if it states a refusal to assist, without the further allegation that the prisoner did not, in fact, assist: $R v$ Sherlock (1866).

Since this case cited no authorities and merely determined the adequacy of the indictment, it does not assist matters further.

In conclusion, Brown (1841) stated the essence of the modern day offence. It is a pity that Alderson B, however, did not analyse the prior legal history of this offence.

\section{Writers in the $20^{\text {th }}$ Century}

Since these decisions, there has been very little commentary on the offence by legal writers. Gabbett (in 1843) did not deal with the matter. ${ }^{339}$ Nor did Sir James Fitzjames Stephen in his History of the Criminal Law of England in 1883 or in his other works. ${ }^{340}$ Harris (writing in 1881) referred to Brown ${ }^{341}$ and Kenny (in 1929) referred to Sherlock. ${ }^{342}$ A later edition of Harris (in 1950) gave a fuller summary of Brown, viz:

To refuse to aid a constable in the execution of his duty to preserve the peace is a common law misdemeanor, provided that (i) a [BOTP] was being committed in the presence of the constable, and (ii) there was a reasonable necessity for the constable to call upon the accused for his assistance, and (iii) that the accused was duly called on for his assistance, and without any physical impossibility or lawful excuse refused to give it: whether the aid of the accused would have proved sufficient or useful is immaterial. ${ }^{343}$

Cross and Jones (1949) $)^{344}$ and Smith and Hogan (1965) did not deal with the matter. Turner, who edited the final edition of Kenny's Outlines of Criminal Law in 1966 stated:

A police constable, even when acting without a warrant, has powers still more extensive than those of a private person. Moreover, as his official position renders it in all these cases a duty for him to make the arrest, it will, in any of them, be a duty, even for an innocent person, to submit to him and not arrest. He is entitled to call for the assistance of any able-bodied by stander, if necessary, $R v$ Brown (1841), and it is an offence at common law for a person so called upon to refuse to assist when reasonably able to do so. $^{345}$

The final edition of Russell on Crime in 1964 (also edited by Turner) stated with reference to Brown (1841): ${ }^{346}$

every citizen has a duty to render assistance to a police officer in the execution of his office in order to preserve the peace or to arrest delinquents, when reasonably called upon and reasonably able to do so. ${ }^{347}$

In the context of riot, Turner referred to the Acts of 1393, 1411 and 1414 (see 15(a)) and the use of the posse

\footnotetext{
339 See $n 163$.

${ }^{340}$ JF Stephen \& H Stephen, A Digest of the Law of Criminal Procedure in Indictable Offences (1883) dealt with JP's and coroners, but not constables. See also ns $170 \& 171$.

${ }^{341}$ Harris n 168, p 80 'Not only positively obstructing an officer, but also refusing to aid him in the execution of his duty in order to preserve the peace, is a crime. The latter offence is a misdemeanor at common law.' He cites Brown.

${ }^{342}$ Kenny, n 182, (1929 ed), p 450 'A police constable, even when acting without a warrant, has powers still more extensive than those of a private person. Moreover, as his official position renders it in all these cases a duty for him to make the arrest, it will, in any of them, be a duty, even for an innocent person, to submit to him and not resist arrest. He is entitled to call for the assistance of any able-bodied bystander, if necessary; L.R.1.C.C.R. 20 [ie. $R v$ Sherlock].

${ }^{343}$ Harris, $\mathrm{n} 168$ ( $18^{\text {th }}$ ed, 1950, ed Wilshere), p 135. Reference is made to Brown. For a useful summary of local cases in which refusing to assist a police officer was brought before JP's see British Newspaper Archive www.britishnewspaperarchive.co.uk (wordsearch 'refusing to assist a police officer'). The Archive covers 261 local newspapers from 1700 on wards (online). What is interesting is how relatively few cases there were of a charge of refusing to assist brought in the $19^{\text {th }}$ century - and, even more so - how few were successfully sustained.

${ }^{344}$ See $\mathrm{n} 24$.

${ }^{345}$ See n 24, pp 579-80

${ }^{346}$ Russell, $\mathrm{n}$ 158, vol 1, 402.' Ibid, p 603 'In case of a riot, if a constable sees a [BOTP] committed he may call upon everyone present for his assistance if there is reasonable necessity therefor. If the person called upon, without any particular responsibility or lawful excuse refuse to do so, he is liable to be indicted, and it is no defence that in consequence of the number of rioters the single aid of the person called upon should have been of no use.'

${ }^{347}$ Ibid.
} 
(albeit long obsolete by 1964). ${ }^{348}$ He noted it was an indictable misdemeanour to refuse to aid a constable in suppressing a riot or affray. On the suppression of riots, Turner cited Tindal CJ in his charge to the grand jury at Bristol (1832) ${ }^{349}$ where the latter stated:

by the common law, not only is each private subject bound to exert himself to the utmost, but every sheriff, constable, and other peace officer, is called upon to do all that in them lies for the suppression of riot, and each has authority to command all other subjects of the king to assist them in their undertaking. 350

Referring to the Act of 1414, Tindal CJ also stated:

every man is bound, when called upon, under pain of fine or imprisonment, to yield a ready and implicit obedience to the call of the magistrate, and to do his utmost in assisting him to suppress any tumultuous assembly. $^{351}$

Although the Acts of 1393, 1411 and 1414 have been repealed, Tindal CJ (correctly, it is asserted) observed that these Acts applied to male subjects only. In respect of affray, Turner stated:

A constable...is also bound, in case of need, to call for the assistance of others, who, on refusal, are guilty of misdemeanour and liable to fine and imprisonment. ${ }^{352}$

Finally, in 1976, a case on a refusal to assist a police constable arose. It would appear to have been the first after Brown. In Waugh ${ }^{353}$ a London transport ticket collector was convicted for refusing to help a woman police officer who was struggling to detain a suspected thief. Nicholson noted that:

Waugh was convicted despite alleging fear and instructions by London transport not to leave his ticket collecting post. ${ }^{354}$

In conclusion, legal writers after Brown (1841) have done little more than cite the case.

\section{Nicholson \& Modern Texts}

In 1992, Nicholson wrote an article on the citizen's legal duty to assist the police. ${ }^{355}$ However, the validity of this article is not assisted by certain preliminary statements being incorrect, viz.

- Nicholson started from the premise that 'Historically all citizens were legally responsible, both for enforcing the law and maintaining the peace. ${ }^{356}$ This is incorrect. At most, in Anglo-Saxon and early medieval times, frankpledge related to able-bodied male subjects of a certain age who were obliged to prosecute the hue and cry and who pledged to observe the king's peace for themselves and the others in their tithing. Thus, all citizens were not responsible for enforcing the law and maintaining the peace;

- Nicholson also stated that the 'first reported appearance of the common law offence was in 1841 in Brown. ${ }^{357}$ This is incorrect as the previous pages of this article elicit. Further, Alderson B, in Brown, never said that he was creating a common law offence. He was clarifying one that previously existed.

Nicholson also supported the abolition of this offence, which is considered in section $\mathbf{2 4}$. As to modern texts on

\footnotetext{
${ }^{348}$ Ibid, p 268 'The first two [Acts] require the use of the posse comitatus [in a footnote he stated 'ie. the levy of all able bodied men in the county'], by the sheriff etc in cases of riot, rout and unlawful assembly, and authorise the arrest of offenders and the recording of offences committed in the presence of the justices. The third provides for the case of default by justices in enforcing the Act of 1411, and prescribes punishment for great and petty riots and for neglecting to aid in suppressing riot.'

3493 ST (NS) 1 (every sheriff, magistrate, constable, and peace officer has authority to command every other subject of the Crown to assist him in the undertaking, and every man is bound, when called upon, to obey that call). Tindal gave his charge to the grand jury at the opening of the special Commission at Bristol on 2 January, 1832, in respect of the Bristol riots which had previously taken place. See also Russell, n 158, vol 1, p 271. See also $R v$ Pinney (1832) 3 ST (NS) 12, 519 (per Littledale J).

${ }^{350}$ At $\mathrm{p} 6$.

${ }^{351}$ See also $R$ v Neale (1839) 9 C \& P 431 (173 ER 899), 3 ST (NS) 1312-4 (case relates to unlawful assembly).

${ }^{352}$ Russell (ed Turner, 1964), n 158, vol 1, p 273. As to nightwalkers, vol 2, p 1398 stated : 'The old law as nightwalking seems to have been connected with the curfew, and power to arrest strangers passing in the night was given by the statute of Wynton, 13 Edw 1, st 2, c 4 repealed in 1827 (7 \& 8 Geo 4 c 27).'

353 The Times, 1 October, 1976.

${ }^{354}$ D Nicholson, The Citizen's Legal Duty to Assist the Police [1992] Crim LR 611, p 617. See also ME Bennun, The Duty to Assist the Police - Some Aspects, in D Lasok (ed), Fundamental Duties (Pergamon Press, 1980), ch 11.

355 Ibid.

${ }^{356}$ At $\mathrm{p}$ 611. As authority for this Nicholson cited Allen, n 85 (Hamlyn Lectures), ch 4 and of L Radzinowicz A History of English Criminal Law and its Administration from 1750 (1948-84), vol 4, p 105 et seq. However, neither made such a bald statement.

${ }^{357}$ Ibid.
} 
criminal law, ${ }^{358}$ very few deal with the matter. ${ }^{359}$ One that does, is Smith and Hogan (2011). It comments:

It is a common law offence for $\mathrm{D}$ to refuse to go to the aid of a constable who, on seeing a [BOTP], calls on $\mathrm{D}$ to assist him in restoring the peace. A ticket collector was held to be guilty of the offence when he failed to come to the assistance of a police-woman struggling with a thief. There must be a reasonable necessity for the constable to request assistance. It is no defence that D's aid would have been ineffective. So where a constable requested $\mathrm{D}$ to assist him in suppressing a [BOTP] among four or five hundred people at a prizefight, Alderson B directed that D's refusal was an offence. It seems that it was no answer that he had horses to take care of. ${ }^{360}$ Alderson B recognized that physical impossibility or lawful excuse would be an answer; but it is not clear what would constitute 'lawful excuse'.

Is the citizen required to act where there would be a grave risk of death or serious injury? Surely the state cannot criminalize D for a failure to put his life on the line ? By s 65(3) of the Serious Crime Act 2007 a person does not perform an act capable of assisting or encouraging crime by the offender merely because he fails to respond to a constable's request for assistance in preventing a [BOTP]. ${ }^{361}$ (wording divided for ease of reference)

For its part, Halsbury states:

in case of necessity, a constable acting in the execution of his duty is entitled to demand the assistance of private persons and it is an offence to refuse it. ${ }^{362}$

It is asserted this statement is incorrect since the obligation is only placed on able-bodied male subjects of a certain age. Further, the offence relates to failing to assist a police officer re a BOTP only and not generally. Also, it is subject to the limitations of Brown. Therefore, the statement in Halsbury is mis-leading.

In conclusion, modern legal texts have scarcely dealt with the issue.

\section{A Statutory Offence - Refusing to Assist A Constable}

Nicholson (writing in 1992) asserted that - if this common law offence was to survive - the principal of legality required that it be placed on a clear statutory footing. ${ }^{363}$ One would agree. The best, present, statement as to this offence would seem to be that of Archbold viz.

Refusing to aid and assist a constable in the execution of his duty, in order to preserve the peace, is an indictable misdemeanor at common law. ${ }^{364}$

For a statutory offence, however, certain matters need to be clarified.

- $\quad$ Aid \& Assist. Archbold refers 'aid and assist'. This duplication of wording, it is believed, likely comes from Fitzherbert and the many editions of his work on the Justice of the Peace, since he employed this wording. Yet, there is no reason to suppose that Fitzherbert intended to make a distinction between these words. Thus, today, the word 'assist' is sufficient;

- Constable. With headboroughs, high constables etc having gone, reference to a 'police constable' would seem accurate; ${ }^{365}$

- Course of his Duty. The constable should be acting in the course of his duty, when he requests assistance and not, for example, when off duty; ${ }^{366}$

\footnotetext{
${ }^{358}$ See $\mathrm{n} 24$. See also ATH Smith, The Offences against Public Order (London, 1987), p 83 'there is no duty in the citizen to intervene [to stop a riot] unless specifically called upon (which in the context of modern policing, he is most unlikely to be).' It cites Brown.

359 This includes Baker (see $n$ 24). See also $2^{\text {nd }}$ ed (1983).

${ }^{360}$ This appears to be a mis-statement. It was no answer because the jury, obviously, considered the excuse to be insufficient (not lawful).

${ }^{361}$ Smith and Hogan, $\mathrm{n} 24$, pp 254-5. The first edition in 1965 did not comment on this offence.

${ }^{362}$ See n $22\left(4^{\text {th }} \mathrm{ed}\right)$, vol 36(1), para 480.

${ }^{363}$ Nicholson, n 354, p 620.

364 See $n 241$.

${ }^{365}$ In modern times, as well as members of the regular police forces there are: (a) special constables (which appear to also cover airport constables); (b) Ministry of Defence police; (c) Civil Nuclear constabulary; (d) British Transport police; (f) harbour police. (Also, there are park police. However, along with water bailiffs, fishery officers and prison officers, they have only limited police functions). It would seem reasonable that a statutory offence also apply in respect of them. See generally, Halsbury, n 22, vol 36(1), paras 119-133. As to university police, Oxford university no longer retains the same and the Cambridge university constabulary do not undertake, in practice, policing functions.
} 
- Who is Obliged ? Today, it is asserted the offence should only be capable of being committed by a male subject over the age of 16 (the age a man is able to vote). One who is, as Alderson B put it in Brown (1841) 'without any physical impossibility or lawful excuse'. Further, there should be an upper age limit (60 would seem reasonable). That is not to say that a constable cannot request, for example a woman, a boy or a man over 60 to assist. ${ }^{367}$ However, they should not be held to have committed an offence if they refuse. Further, the male should be a British subject since the obligation in respect of frankpledge, hue and cry and the posse were based on allegiance to the sovereign. Also, it would not seem appropriate to extend the obligations to others. For example, to a foreigner since he might not understand the language or what was being requested of him. In conclusion, this offence should only be capable of being committed by a British subject aged 15-60 years old, who is not otherwise physically incapable of assisting or has a lawful excuse; ${ }^{368}$

- On the Spot. The Acts of 1393, 1411 and 1414 concerning riots envisaged subjects joining a posse (whether on foot or horseback) to deal with riots, unlawful assemblies and routs, all of which could be some distance away. These Acts have been repealed. As to the common law offence of hue and cry, it seems that it was, generally, limited to the constable's jurisdiction, his 'view. ${ }^{369}$ For any modern statutory offence, with the posse and hue and cry being obsolete, it would seem reasonable - following the fact situations in Brown and Sherlock - to limit any request by a constable to assistance 'on the spot'; 370

- BOTP. Modern formulations of this offence, such as that of Halsbury, are too wide and even that of Archbold is not clear. The obligation should be restricted to being required to assist a constable in order to prevent a 'BOTP'. ${ }^{371}$ What, however, comprises BOTP for present purposes? In Anglo- Saxon and Anglo-Saxon times it meant one thing. ${ }^{372}$ Lambard (in 1599) understood it to mean 'not only that fighting, which we commonly call the BOTP, but also that every murder, rape, manslaughter, and felony whatsoever, and every affraying (or putting in fear) of the Queen's people, whether it be by unlawful wearing of armour, or by assembly of people to do any unlawful act, are taken to be disturbances of the peace. ${ }^{373}$ Dalton (in 1619) understood it to mean 'The breach of this peace seems to be any injurious force or violence moved against the person of another, his goods, lands, or other possessions, whether it be by threatening words, or by furious gesture or force of the body, or any other force used in terrorem populi." 374 Today, the meaning of BOTP is unclear ${ }^{375}$ and it should be defined for the purposes of any statutory offence of refusing to assist - not least since the offences

\footnotetext{
${ }^{366}$ It would not seem reasonable to extend the common law offence to cases involving, for example, an off-duty constable who seeks to tackle a bank robber. In times past, in the case of hue and cry and the posse (as well as serving writs and warrants and preventing affrays) the constable was undertaking all this in his official capacity.

${ }^{367}$ It may be noted that in World War I (1914-8), conscription was restricted to men aged 18-41 (later, to age 51), unless widowed with children or they were ministers of religion. In World War II (1939-45), conscription applied to men aged 18-41 not in reserve occupations. In 1941, single women aged 20-30 were conscripted (they did not fight but were placed in reserve occupations), See McBain, n 247, p 54, fn 295.

${ }^{368}$ For example, if the male was in charge of children or elderly people or was directing traffic etc it would not seem lawful for a constable to request his assistance to chase after a suspected thief. It should be noted that assistance could also involve considerable danger, see $R v P h e l p s$ (1841) C \& M 180 (174 ER )(called on by a constable to assist, he was killed).

${ }^{369}$ Constables, especially in London, only had a limited area to patrol. London itself was, in early times, divided into wards, each with its own wardmote (assembly) which usually four times a year, at which nuisances and complaints could be ventilated. Further, in London and elsewhere, there were franchises which had their own constables, who policed only within the physical confines of the same.

${ }^{370}$ Cf. Nicholson, n 354, p 614 'the citizen's duty appears to be limited to 'on the spot' assistance.'

${ }^{371}$ Ibid. p 612 'there has been no suggestion that the citizen's duty extends beyond preserving the peace to all law enforcement duties, beyond preserving the peace, let alone to other public duties such as traffic directions and the rescue of those in peril. Instead, it is limited to assistance in relation to breaches of the peace.'

${ }^{372}$ Allan, $\mathrm{n}$ 85, pp 12-3 stated that BOTP in Anglo-Saxon times comprised the following crimes 'mundbryce, breach of mund [ie. breach of the king's special peace]; hamsocne or housebreaking; foresteal, a term of somewhat doubtful interpretation, but it is generally understood to mean ambush or attack by stealth; fyrdwite, or evading military service...flymena fyrmthe, or the harbouring of thieves.' He asserted it did not cover murder, however. See also P \& M, n 43, vol 2, p 453 'We may think that every crime can be esteemed a breach of the king's peace; but... it only covered deeds of violence done to persons, or at places, or in short seasons that were especially protected by royal power.' See also F Pollock, Oxford Lectures and Other Discourses (1890), ch 3 (the king's peace). For the extension of the king's peace in Anglo-Norman times, see P \& $\mathrm{M}, \mathrm{n}$ 43, vol 2, pp 463-4.

373 See $n 287$.

374 See n 297.

${ }^{375}$ Halsbury, n 22, vol 36(1)(4 $4^{\text {th }}$ ed), para 478. See also Glasbrook Bros Ltd v Glamorgan CC [1925] AC 270 at 277 per Cave LC and Rice v Connolly [1966] 2 QB 414 at 419 per Parker CJ.
} 
requiring a subject to assist pre-Brown (1841) have all changed. ${ }^{376}$ It is asserted that it should cover only stipulated offences of violence (including sexual offences) but not, for example, forgery or fraud etc; 377

- Immunity. It would seem only appropriate to provide - especially in modern times which are so litigious - that a person assisting a police constable (whether at his request or not) has criminal and civil immunity, providing he acts reasonably. Otherwise, no citizen would want to assist in any case, ${ }^{378}$

- Punishment. In respect of the hue and cry, a person could be fined. ${ }^{379}$ In the case of the Acts of 1393, 1411 and 1414 a person could also be imprisoned. ${ }^{380}$ So too, in the case of affray. ${ }^{381}$ Imprisonment was not, and would not today, seem appropriate.

Today, unlike times past, the police are highly organised and professional. Thus, they do not need to call on members of the public and, indeed, do not usually wish to - since this will often result in greater problems that benefit. However, it seems appropriate that there be an offence and that the general public should be encouraged to help, in times of necessity. Given this, a modern statutory formulation is apposite and it should be clear.

- A possible formulation is contained in Appendix A. What crimes should be covered is important although the number of assailants should not be a pre-requisite; ${ }^{382}$

- It would also seem appropriate that - in general - a person (including any relevant person) who assists a police constable in the execution of his duty, when requested, should be accorded with full civil and criminal immunity for any act(s) performed by him (or her) in assisting, providing they act as a reasonable person would in the circumstances. ${ }^{383}$ Otherwise, citizens will likely refuse to help for fear of possible negative legal consequences. "

\section{Abolish the Offence of Refusing to Assist A Constable?}

Would it be an idea to simply abolish this common law crime? Nicholson (writing in 1992) was in favour of this. He stated:

The potential for infringing the already much threatened civil liberties of British citizens suggest that the offence of refusing to assist in preserving the peace is best viewed as an anachronistic hangover from an era predating an effective professional police force...it is contended that, rather than clarifying this outdated and problematic offence, it should be laid to rest. ${ }^{384}$

One would dis-agree for the following reasons:

\footnotetext{
${ }^{376}$ Thus, affray no longer exists as a crime as such, bawdry and nightwalking are no longer offences, the Riot Acts 1393,1411 and 1414 have been repealed, the hue and cry and posse are obsolete and constables do not require assistance serving writs (now claim forms) or warrants.

${ }^{377}$ In the case of the offence pre-Brown, the key was violence (or the threat of it), especially communal violence which one (or two) police constables might not have been able to handle on their own. McBain, $\mathrm{n} 151$, lists all the general crimes contained in legislation. With reference to this list, it is asserted that the crime should only be committed with reference to: (a) serious offences of violence which likely affect the public in general (but not assault); (b) a limited number of sexual offences which likely affect the public in general as contained in the Sexual Offences Act 2003 (but not offences relating to indecency, obscenity, outraging public decency); (c) a limited number of financial crimes such as theft, robbery and burglary (but not criminal damage or other financial crimes, see n 151, pp 19-20); (d) serious offences of public order such as riot, violent disorder and affray in the Public Order Act 1986 (but not, for example, offences relating to official secrets, criminal trespass or endeavouring to break up a public meeting, see n 151, pp 20-1). In respect of common law offences it should (probably) not cover kidnapping or assisting escape (a person who intentionally helps another to escape by refusing to assist a police officer should be covered within that separate offence). For a possible list, see Appendix B.

${ }^{378}$ A person who assisted in hue and cry was protected. See also Russell (ed Turner, 1964), n 158, vol 1, pp 662 'The protection which the law affords to ministers of justice extends also to every person coming to their aid and lending his assistance for the keeping of the peace etc., or attending for that purpose, whether commanded or not, provided that the offender has knowledge or notice that they are so acting in assistance.' Cf. $R v$ Phelps (see $\mathrm{n}$ 368). Also, the very onerous case of Walters $v$ WH Smith \& Son Ltd [1914] 1 KB 595 (to justify an arrest a private citizen must show that the particular felony for which he arrested was, in fact, committed. In this case a citizen arrested another on suspicion he had stolen a book). See also (1914) $30 \mathrm{LQR}, \mathrm{p} 146$.

379 See 267 (Act of 1275, a 'grevious fine').

${ }^{380}$ See $\mathrm{n} 278$ (Act of 1414, 'imprisonment, and to make fine and ransom to the king.')

${ }^{381}$ See $\mathrm{n} 281$ (Coke, fine or imprisonment).

${ }^{382}$ In Brown (see $\mathrm{n} 332$ ), Alderson B referred to a '[BOTP] committed by two or more persons'. However, this was not a requirement under the old law in the case of felonies (murder, theft etc), nor nightwalkers, and there would seem no good reason why it should be a statutory requirement (since a constable may struggle with even one person).

${ }^{383}$ Acting reasonably, for example, would be to help a constable detain a suspected thief running away from the scene. Acting unreasonably, for example, would be to deliberately kill a suspected their. See also $R v$ Phelps (see $\mathrm{n} 368$ ).

${ }^{384}$ Nicholson, n 354, p 621.
} 
- In modern times, it is most unlikely a police constable would call for assistance from a member of the public to prevent a crime. ${ }^{385}$ Rather, they would rely on professional colleagues as well as the very considerable range of resources they possess. If a constable did ask for assistance, therefore, it would rare, and the fact that there (it seems) have been only three reported cases since 1841 as to this offence, ${ }^{386}$ suggests that it is unlikely the police would seek to mis-use any obligation to assist;

- There are cases, where it would seem right (and appropriate) that able-bodied males at the scene where a crime is being committed, help to suppress violence. For example, it is likely most people in the UK would be appalled if a woman was being raped (or a person was being beaten to death) and able-bodied British male subjects stood by - and did nothing - when a single police constable was unable to cope. Especially so, if the victim was a child or a vulnerable person. Reasonable, and law abiding, members of society would, I believe, be revolted against such inaction. Thus, there should not just be a moral duty to assist. It should be a legal one in such circumstances;

- Self-help remedies such as the hue and cry and the posse - as well as cases where the courts sought to prevent prize fights ${ }^{387}$ demonstrate that the rule of law, at times, can only be upheld if there is active co-operation by members of society to help stop violence. It cannot simply be left to the police to uphold law and order in every cirumstance.

Thus, one would dis-agree with Nicholson. Although frankpledge, the hue and cry and the posse may be obsolete (together with allegiance to the Crown, which directed them), there should still remain an obligation, in rare circumstances, on British subjects to do what they can to uphold the law since, observing it, brings the greatest benefits to society as a whole. Further, persons who do assist the police should be entitled to the greatest degree of immunity (civil and criminal), providing they act reasonably.

\section{Conclusion - Refusing to Assist a Constable}

It is asserted that there should continue to be an crime of refusing to assist a police constable in the execution of his duty. However, this should be statutory - and it should be tightly drawn. It would also be appropriate to abolish the obligations of: (a) frankpledge; and (b) hue and cry, at common law since they are now long obsolete. Possible statutory wording for this crime is contained in Appendix A.

\section{$\underline{\text { Appendix A: Draft Statutory Formulation }}$}

\section{Unlawful Detention}

(a) It is a crime to unlawfully detain a person. ${ }^{388}$

(b) The punishment is imprisonment for a maximum period of up to [ ] years and/or a fine up to level [ ] on the scale.

(c) No crime is committed if the person detained is:

(i) in lawful custody; ${ }^{389}$ or

(ii) under the age of 16 and subject to reasonable parental supervision.

\section{Assisting a Police Constable}

(a) A person who:

(i) assists a constable acting in the execution of his duty

(ii) when requested by the same ${ }^{390}$

\footnotetext{
${ }^{385}$ In the case of riots, any common law obligation on members of the public to assist to suppress them, without being called on by the police, would seem inappropriate in modern times and should be abolished.

${ }^{386}$ Brown, Sherlock and Waugh.

387 See n 331.

${ }^{388}$ False Imprisonment (Faux emprisonment). The Anglo-Norman word 'faux' meant unlawful (or illegal) and 'emprisonment' was not restricted to incarceration in a prison but included a constable's lock up (police cell or cage), the stocks, the pillory and arrest by a constable. The statutory crime could, alternatively, be called 'Unlawful Imprisonment'. However, the problem with this, is that the word 'imprisonment' suggests a prison (jail) when the crime has always been much wider than that.

${ }^{389}$ This should match up with the offence of escape and assisting escape (see n 1) since lawful custody cannot, ipso facto, constitute unlawful detention. The word 'custody' may be replaced with that of 'detention'. Both words include physical 'restraint'.

${ }^{390}$ This would apply not just when there is an obligation to assist under s 3, but generally.
} 
(iii) shall have full civil, and criminal, immunity for his acts

(iv) providing he acts as a reasonable person would in the circumstances.

\section{Refusing to Assist a Police Constable}

(a) It is a crime for a relevant person (the 'person') to refuse to assist a constable if:

(i) the constable is acting in the execution of his duty

(ii) to prevent a crime listed in Appendix 1 and

(iii) there is reasonable necessity for him to call on the person to assist and

(iv) the person is present at the scene and

(v) the person refuses to assist.

(b) The punishment is a fine up to level [ ] on the scale.

'Relevant person' means a British male subject between 16 and 60 years who is: (a) physically capable of assisting; and (b) does not otherwise have a lawful excuse.

'Police constable' includes any: (a) special constable; (b) member of the Ministry of Defence police; (c) member of the Civil Nuclear constabulary; (d) member of the British Transport police; (e) harbour constable; (f) civil aviation and airport constable. ${ }^{391}$

\section{Abolition of Frankpledge and Hue and Cry}

(a) The obligations of frankpledge and hue and cry are abolished.

\section{Appendix 1}

(a) murder;

(b) battery; ${ }^{392}$

(c) assault occasioning actual bodily harm (Offences against the Person Act 1861, s 47)

(d) wounding or causing grevious bodily harm (Offences against the Person Act 1861, s 18)

(e) wounding or inflicting grevious bodily harm (Offences against the Person Act 1861, s 20)

(f) rape (Sexual Offences Act 2003, s 1)

(g) assault by penetration (Sexual Offences Act 2003, s 2)

(h) sexual assault (Sexual Offences Act 2003, s 3)

(i) rape and other offences against children under 13 (Sexual Offences Act 2003, ss 5-8)

(j) theft (Theft Act 1968, s 7)

(k) robbery (Theft Act 1968, s 8)

(1) burglary (Theft Act 1968, s 9)

(m) aggravated burglary (Theft Act 1968, s 10) ${ }^{393}$

(n) making off without payment (Theft Act 1978, s 3).

\section{Copyrights}

Copyright for this article is retained by the author(s), with first publication rights granted to the journal.

This is an open-access article distributed under the terms and conditions of the Creative Commons Attribution license (http://creativecommons.org/licenses/by/3.0/).

\footnotetext{
${ }^{391}$ It would not seem necessary to include park police etc, see n 365 .

${ }^{392}$ It would not seem appropriate where there is only assault, but no battery. Nor, probably, in the case of assaulting a police officer pursuant to the Police Act 1996, s 89(1).

${ }^{393}$ It would not seem appropriate to cover other crimes in this Act such as: (a) removing articles from places open to the public (s 11), taking a vehicle or other conveyance without authority (s 12), aggravated vehicle taking (s 12A), abstracting electricity (s 13).
} 